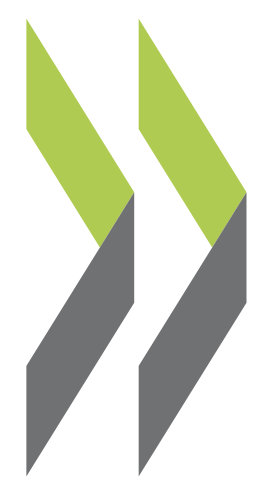

OECD Economics Department Working Papers No. 1606

Measuring occupational entry regulations: A new OECD approach

Christina von Rueden, Indre Bambalaite 


\section{ECONOMICS DEPARTMENT}

\section{MEASURING OCCUPATIONAL ENTRY REGULATIONS: A NEW OECD APPROACH}

\section{ECONOMICS DEPARTMENT WORKING PAPERS No. 1606}

By Christina von Rueden and Indre Bambalaite

OECD Working Papers should not be reported as representing the official views of the OECD or of its member countries. The opinions expressed and arguments employed are those of the author(s).

Authorised for publication by Luiz de Mello, Director, Policy Studies Branch, Economics Department.

All Economics Department Working Papers are available at www.oecd.org/eco/workingpapers.

JT03459053 
OECD Working Papers should not be reported as representing the official views of the OECD or of its member countries. The opinions expressed and arguments employed are those of the author(s).

Working Papers describe preliminary results or research in progress by the author(s) and are published to stimulate discussion on a broad range of issues on which the OECD works.

Comments on Working Papers are welcomed, and may be sent to OECD Economics Department, 2 rue André Pascal, 75775 Paris Cedex 16, France, or by e-mail to eco.contact@oecd.org.

All Economics Department Working Papers are available at www.oecd.org/eco/workingpapers

This document and any map included herein are without prejudice to the status of or sovereignty over any territory, to the delimitation of international frontiers and boundaries and to the name of any territory, city or area.

The statistical data for Israel are supplied by and under the responsibility of the relevant Israeli authorities. The use of such data by the OECD is without prejudice to the status of the Golan Heights, East Jerusalem and Israeli settlements in the West Bank under the terms of international law.

(C) OECD (2020)

You can copy, download or print OECD content for your own use, and you can include excerpts from OECD publications, databases and multimedia products in your own documents, presentations, blogs, websites and teaching materials, provided that suitable acknowledgment of OECD as source and copyright owner is given. All requests for commercial use and translation rights should be submitted to rights@oecd.org 


\section{ABSTRACT /RESUME}

\section{Measuring occupational entry regulations: a new OECD approach}

This paper explores cross-country differences in the design and stringency of occupational entry regulations (OER) in five professional services, nine personal services and nurses, based on a new composite indicator. The indicator - which is available for a total of 18 OECD countries, India and South Africa, with Canada and the United States being covered at the province-level or state-level - provides a comparative source of information on the various approaches used across countries to regulate entry into services. It notably distinguishes between different areas of regulation (administrative, qualification and mobility requirements) and different types of regulation (licensing, a situation in which only supervisors require a license, and certification). According to these metrics, the stringency of OER varies significantly across occupations, with stark differences emerging between personal and professional services, which are typically subject to far stricter entry requirements. Regulatory approaches also vary widely between countries, and more strikingly, even within broad economic areas, such as the European Union, the United States and Canada, suggesting unfinished economic integration agendas. Lastly, the indicator reveals that OER almost always take the form of licensing requirements, the most stringent form of regulation, with only a handful of exceptions in European countries and Canadian provinces.

JEL classification codes: J44 ; L5; O57.

Keywords: occupational licensing; regulations.

\section{Mesurer la réglementation de l'accès aux professions : la nouvelle approche de l'OCDE}

Ce rapport étudie les variations entre les pays dans la conception et la rigueur de la réglementation de l'accès aux professions dans différents secteurs, à savoir cinq services professionnels, neuf services à la personne et les services infirmiers, au moyen d'un nouvel indicateur composite. Cet indicateur - qui couvre 18 pays de I'OCDE, I'Inde et l'Afrique du Sud, ainsi que le Canada et les États-Unis au niveau des provinces et des États - fournit des données comparatives sur les différentes approches suivies par les pays pour réglementer l'entrée dans les professions de services. II fait notamment la distinction entre différents volets de la réglementation (dispositions administratives, niveau de qualification et exigences en termes de mobilité) et différents types de réglementation (autorisations d'exercice, cas où seules les autorités de tutelle nécessitent une autorisation, et agrément). II en ressort que la rigueur de la réglementation de l'accès aux professions varie considérablement d'une profession à l'autre, avec des disparités très marquées entre les services à la personne et les services professionnels, qui sont généralement soumis à des conditions d'entrée beaucoup plus strictes. Les approches suivies en matière de réglementation diffèrent aussi sensiblement entre les pays et, de manière encore plus frappante, au sein même de grandes zones économiques, comme l'Union européenne, les États-Unis ou le Canada, ce qui laisse à penser que les programmes d'intégration économique restent en suspens. Enfin, l'indicateur montre que la réglementation de l'accès aux professions passe quasiment systématiquement par l'autorisation d'exercice, soit la forme de réglementation la plus stricte, à quelques rares exceptions près parmi les pays européens et les provinces canadiennes.

Classification JEL: J44 ; L5; O57.

Mots-clés : autorisations d'exercice; réglementation. 


\section{Table of contents}

Measuring occupational entry regulations: a new OECD approach 6

1. Introduction 6

2. The OER approach to measuring occupational entry regulations 8

2.1. How the OER helps fill crucial data gaps 8

2.2. Data sources, coverage and indicator structure 9

2.3. Limitations and interpretative pitfalls 12

3. Cross-country differences in OER 14

3.1. A first glance at the data 14

3.2. Detailed results - OECD countries 20

3.3. Detailed results - Non-OECD countries 31

4. Policy recommendations and conclusions 33

References $\quad 35$

Annex A. Additional descriptive statistics 38

Annex B. Description of the core activities of the professions included in the analysis 40

Annex C. Detailed weighting scheme of the OER indicator 43

Annex D. The OER questionnaire $\quad 45$

Annex E. Abbreviations of countries, states and provinces $\quad 48$

Annex F. Comparison of the indicators measuring occupational regulations $\quad 50$

Annex G. Values of OER indicator 52

Tables

Table 1. Countries and occupations covered by the indicator $\quad 10$

Table 2. Summary statistics OER indicator by profession $\quad 17$

Table 3. Selected occupational entry reforms: Europe 24

Table 4. Selected occupational entry reforms: United States $\quad 27$

Table 5. Selected occupational entry reforms: Canada 29

$\begin{array}{ll}\text { Table B.1. Core activities by occupation } & 40\end{array}$

Table C.1. Weighting scheme $\quad 44$

$\begin{array}{lr}\text { Table D.1. Questionnaire } & 45\end{array}$

$\begin{array}{lr}\text { Table E.1. Abbreviations of countries } & 48\end{array}$ 
Table E.2. Abbreviations of US states

Table E.3. Abbreviations of Canadian provinces $\quad 49$

Table F.1. Comparison of the indicators measuring occupational regulations $\quad 50$

Table G.1. Values of OER indicator $\quad 52$

\section{Figures}

Figure 1. Correlation between the OER indicator and the OECD Product Market Regulation indicator in the area of professional services

Figure 2. Structure of the new OECD Occupational Entry Regulations (OER) indicator 12

$\begin{array}{lr}\text { Figure 3. OER indicator by profession and country group } & 17\end{array}$

Figure 4. Total OER indicator by country 18

Figure 5. Licensing systems dominate occupational regulations $\quad 19$

Figure 6. The dispersion of regulatory approaches within economic areas suggests incomplete economic integration

Figure 7. Cross-country variation in OER of general care nurses

Figure 8. The share of the workforce holding an occupational license in the EU (2015)

Figure 9. Within-country variance of regulatory stringency across occupations: Europe 22

Figure 10. Composition of average regulation by sub-indicator: Europe 23

Figure 11. The share of the workforce holding an occupational license in the United States (2013) 24

Figure 12. Within-country variance of regulatory stringency across occupations: US

Figure 13. Composition of average regulation by sub-indicator: US states 26

Figure 14. Within-country variance of regulatory stringency across occupations: Canadian provinces 28

Figure 15. Composition of average regulation by sub-indicator: Canada 29

Figure 16. Composition of average regulation by sub-indicator: Israel $\quad 30$

Figure 17. Occupational licensing in Israel historically follows an upward trend $\quad 31$

Figure 18. Composition of average regulation by sub-indicator: India 32

Figure 19. Composition of average regulation by sub-indicator: South Africa 33

Figure A.1. The cross-country or cross-state variability of regulations differs significantly across occupations 38

Figure A.2. Population weighted average OER values 39

\section{Boxes}

Box 1. The complex role of professional associations 14

Box 2. Occupational entry regulations in the health sector - the example of nurses 20 


\title{
Measuring occupational entry regulations: a new OECD approach
}

\author{
By Christina von Rueden and Indre Bambalaite ${ }^{1}$
}

\section{Introduction ${ }^{2}$}

1. Occupational licensing requirements respond to well established public policy objectives - such as the satisfaction, health and safety of consumers. To this end, they set the administrative, qualification, cross - jurisdictional mobility and other requirements (such as those affecting conduct) for being allowed to provide professional or personal services in certain areas. In the European Union (EU) and the United States (US), where the contribution of professional and personal services to economic activity is high and rising, the share of workers covered by licensing requirements alone is estimated to account for $15-35$ $\%$ depending on the country or State (Johnson and Kleiner, 2017; Blair and Chung, 2018; Koumenta and Pagliero, 2017), with the US share having increased five-fold over the past few decades (Kleiner and Krueger, 2010). Considering the sizeable share of workers affected by licensing requirements and in turn, their potentially important repercussions on the economy, researchers and policy makers increasingly seek to better gauge their scope and implications.

2. While recent research has provided estimates of the share of workers covered by licensing requirements, knowledge about their intensity and scope is often limited to anecdotal evidence or based on selected countries and occupations. This paper helps filling this gap by presenting a new cross-country indicator of the stringency of licensing requirements focusing specifically on occupational entry regulations

\footnotetext{
1 Corresponding authors are Christina von Rueden (Christina.VONRUEDEN@oecd.org) and Indre Bambalaite (Indre.BAMBALAITE@oecd.org) from the OECD Economics Department. The authors would like to thank Giuseppe Nicoletti for his very valuable contribution to this paper, and Luiz de Mello, Alain de Serres, Hansjörg Blöchliger, Mikkel Hermansen, Cristiana Vitale, Dorothée Rouzet, Peter Gal, Stéphane Sorbe (all from the OECD Economics Department), participants in an internal OECD seminar and delegates of the Working Party 1 of the OECD Economic Policy Committee for their useful comments. Special thanks also go to Jason Hicks, Morris M. Kleiner and Wenchen Wang (all University of Minnesota) for assembling the data for the United States and providing precious suggestions; Tingting Zhang (Merrimack College) for the data on Canada; Davud Rostam-Afschar (University of Hohenheim) for the data on Austria; Ulrike Unterhofer (ETH Zurich) for the data on Switzerland; Lukasz Dabros (Warsaw School of Economics) for the data on Poland; Thulisile Radebe (Resbank South Africa) for the data on South Africa; Diksha Gupta (who was an intern at the OECD Economics Department at the time the paper was written) and Yair Osheroff (The Hebrew University of Jerusalem) for the contributions on India and Israel, respectively; Ania Thiemann and António Neto for the data on Iceland and precious advice; and Dilyara Bakhtieva and Tinne Heremans (European Commission) for their advice on EU data collection procedures. Sarah Michelson (also from the Economics Department) provided impeccable editorial assistance.
}

2 The OER database, all graphs and further background material can be found on the dedicated webpage to this project: https://bit.ly/2w4MR2X 
$(\mathrm{OER}){ }^{3}$ Such regulations can be distinguished into three types: (i) licensing (i.e. the mandatory requirement to obtain a legal authorisation to practice), (ii) a situation in which only supervisors require a license, and (iii) certification (i.e. the option to carry a legally protected title). Our indicator not only captures whether a profession is regulated or not, it also accounts for the regulatory intensity by distinguishing between these three types of regulatory approaches. Also, it is based on granular information on three main regulatory areas: administrative burdens, qualification requirements and mobility restrictions. This information was collected for a total of 18 OECD countries, India and South Africa, and covers a set of five professional services (accountant, architect, civil engineer, lawyer, and real-estate agent), nine personal services (aesthetician, baker, butcher, electrician, hairdresser, painter-decorator, plumbers, driving instructors and taxi drivers), and nurses. The data include first-ever data for most jurisdictions, with Canada and the US covered at the province and state level, respectively.

3. The indicator provides a comparative source of information on the various approaches used across countries to regulate entry into services. This is especially useful for countries sharing the same level of development and similar institutional structures, where the acknowledgment of comparatively looser entry regulations abroad pursuing similar public policy objectives could stimulate reflection on the need to review such regulations domestically. The indicator also provides researchers with a quantitative tool to analyse the economic and social effects of occupational entry regulation empirically. A first step in this direction is the companion paper by Bambalaite et al. (2020).

4. Overall, the indicator points to a number of interesting findings. First, across occupations, the stringency of OER differs significantly across countries, reflecting a wide variety of regulatory approaches. Yet, averaging across countries and occupations, regulatory stringency is generally lower in personal services than in professional services, and within the personal service category taxis, driving instructors and electricians are typically more regulated than all other crafts. Second, the stringency of OER varies not only across regions but also within broad economic areas, such as the EU, the US and Canada, suggesting unfinished economic integration agendas, despite the myriad of policy initiatives aimed at facilitating the movement of professionals across these areas. Third, most OER typically take the form of licensing requirements, the most stringent form of regulation, with only a handful of exceptions in European countries.

5. These striking regulatory differences between jurisdictions (even within the same country or economic area) suggest the need to review existing OER to ensure that their design is appropriate for achieving their stated public interest goals. This is also warranted in view of rising empirical evidence (surveyed for instance in Bambalaite et al., 2020) pointing to at best ambiguous and often undesired economic effects of these regulations. Where the need for reform is established, licensing systems could also be replaced with less distortionary or lighter schemes, such as certification, and encourage where possible the development of consumer information digital platforms (e.g. service quality comparison platforms) to alleviate some of the information asymmetry concerns that sometimes justify the OER.

6. The paper first provides the rationale for creating a new OER indicator, briefly surveying and comparing alternative sources of data. Next, section 2.2. provides a detailed description of the indicator's structure before discussing its limitations in section 2.3. Section 3 looks at the results from both a broad cross-country perspective and a more country or area-specific one. Section 4 discusses policy implications and concludes.

\footnotetext{
${ }^{3}$ The indicator does not cover regulations aimed at influencing business conduct, including hygiene or fire safety regulations.
} 


\section{The OER approach to measuring occupational entry regulations}

\subsection{How the OER helps fill crucial data gaps}

7. OER increasingly attract the media's, policy makers' and researchers' attention, but the debate around their economic and social implications remains characterised by the dearth of harmonised and comparable cross-country data on the intensity of entry restrictions. Indeed, research in this area long focused on the United States (see Anderson at al., 2016; Blair and Chung, 2018ab; Carpenter et al., 2018; Chai and Kleiner, 2016; Gittleman et al., 2013; Johnson and Kleiner, 2017; Kleiner, 2006; Kleiner, 2016; Kleiner and Kudrle, 2000; Kleiner and Park, 2014; Kleiner and Krueger, 2010, Klee, 2013), the only country where researchers manually assembled regulatory information over a continued period of time, covering both personal and professional services. European research on the issue only emerged after the European Commission launched the "Regulated Professions Database" 4 in 2013 - compiling raw information on the regulatory requirements of more than 5,000 professions in EU Member States, EEA countries, the UK and Switzerland. In parallel, the OECD has been covering some professional services (lawyers, accountants, engineers and architects since 1998 and real estate agents and notaries since 2018) via the OECD Product Market Regulation database. ${ }^{5}$

8. While these sources are valuable, the information they contain and the indicators they generated are disparate and do not allow for meaningful cross-country comparisons of regulations across countries. This is because differences in focus and country coverage risk attributing disproportionate weight to regulations that are peculiar to specific jurisdictions: for instance, US data sometimes include the treatment of ex-offenders or military spouses, which are not relevant elsewhere. One of the prime motivations for creating a new OER indicator was thus to capture a harmonised set of entry restrictions that are common across a wide set of jurisdictions, including non-OECD economies.

9. Existing regulatory indicators typically also cover only one or few selected occupations. The OECD Product Market Regulation Indicator (PMR), is a case in point, as it includes regulatory information that is not relevant for all occupations. For instance, restrictions on the legal form of the business might matter for professional services, but are likely to play a minor role for personal services. To ensure equal relevance across occupations, the new OER covers in each of them a homogeneous set of restrictions. Thus, for professional services in OECD countries it includes a subset of the information embedded in the latest vintage of the PMR. It is therefore natural that the two indicators are closely correlated for these professions (Figure 1). By restricting the focus on entry regulations that affect a common set of occupations (covering both personal and professional services) the new OER ensures comparability across both occupations and countries.

\footnotetext{
${ }^{4}$ See https://ec.europa.eu/growth/tools-databases/regprof/

${ }^{5}$ See https://www.oecd.org/economy/reform/indicators-of-product-market-regulation/
} 


\section{Figure 1. Correlation between the OER indicator and the OECD Product Market Regulation} indicator in the area of professional services

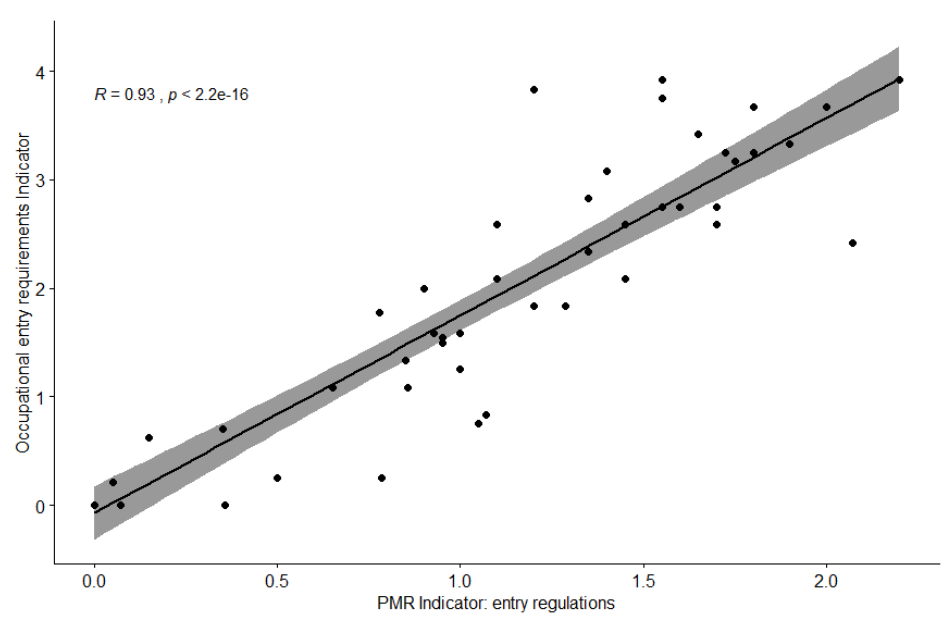

Note: Data refer to the PMR indicator for professional services (subsection "entry requirements") and the full indicator for professional services proposed in this paper.

Source: Authors' calculations; PMR vintage 2018.

10. The new OER also aims at providing a consistent measure of regulatory intensity while preserving its granularity in terms of coverage of regulatory areas. The simultaneous account of these two dimensions (intensity and granularity) is often lacking in existing sources. For instance, most of the available indicators for the US are binary, i.e. only record whether or not a professional license is required. Indicators that account for regulatory intensity (e.g. the PMR) on the other hand, usually contain lesser detail. ${ }^{6}$ The OER measures overall intensity by distinguishing between licensing, a situation in which only supervisors require a license, and certification; and ensures granularity by covering three regulatory areas in detail: administrative burdens, qualification requirements and cross-jurisdictional mobility restrictions.

11. In sum, the OER indicator thus seeks to fill the gaps of the existing measures by providing a metric covering a substantive set of countries (including first-ever estimates for some jurisdictions) and measuring the regulatory intensity of occupational entry burdens, that is designed for a wide range of professional and personal services in a way that can easily be updated or extended to additional countries and occupations. It is therefore suitable for empirical analysis, while providing a useful source of information to better understand the various approaches used by countries to regulate entry into services.

\subsection{Data sources, coverage and indicator structure}

12. The OER indicator covers at this stage a set of five professional services, nine personal services and nurses. It contains data for a total of 18 OECD countries, India and South Africa (see Table 1). Canada and the United States are covered at the province-level and state-level, respectively, where each province (state) is regarded as a separate jurisdiction. Switzerland and India were initially assessed for several cantons and states, but since regulations were found to be almost identical at the subnational level, the canton of Bern and the state of Delhi were designated as being representative. ${ }^{7}$ Whenever regulations

\footnotetext{
${ }^{6}$ To facilitate the comparison between the OER and the most prominent cross-country indicators assessing regulatory entry barriers, Table F.1 provides a comprehensive list of all regulatory aspects covered by each.

7 In Switzerland, the only Canton that appeared to be subject to stricter regulations, e.g. for aestheticians, was Ticino. Additional language-related regulatory requirements were sometimes also found to be in place for Swiss-French or Swiss-Italian Cantons.
} 
differed at the local level (e.g. at the level of the municipality, as is often the case for taxis), the level of regulation imposed by the capital was chosen. ${ }^{8}$

13. Importantly, the indicator only captures legal restrictions to entry into occupations, i.e. regulations restricting the number of service providers (be they self-employed or employees) through legal provisions. These are legal requirements governing the rights to exercise protected activities and hold a legally protected title - which corresponds to our definition of "licensing" - or to holding a legally protected title only - our definition of "certification". The latter case would occur, for instance, if a country only allowed certified architects to use the professional title (i.e. to call themselves "architects") although anyone could theoretically carry out the activities associated with this profession. We thus differ from previous studies in that we exclude voluntary certification and accreditation schemes that are not related to the right of holding a title, and therefore carry no legal implications. ${ }^{9}$ Moreover, we ignore the requirement for professionals to register their name and address with a relevant authority for administrative purposes, since we consider the burden posed by registration to be low enough not to affect professional choices.

14. Whenever possible, the information used to construct the new OER indicator were drawn from the EC Regulatory Professions Database and the OECD Product Market Regulation Indicator. For countries or regulatory areas covered by neither of the two sources, the indicator was built with the help of country consultants, who collected the information manually from legal sources. With the exception of Canada, all indicator values were vetted by countries' authorities.

\section{Table 1. Countries and occupations covered by the indicator}

\begin{tabular}{|c|c|c|c|c|c|}
\hline \multicolumn{3}{|c|}{ Countries } & \multicolumn{3}{|c|}{ Occupations } \\
\hline European & & Non-European & Personal & & Professional \\
\hline Austria & Poland & $\begin{array}{l}\text { Canada** } \\
\text { (province-level) }\end{array}$ & Aesthetician & Hairdresser & Accountant \\
\hline Belgium & Portugal & India (Delhi)* & Baker & $\begin{array}{l}\text { Painter- } \\
\text { decorator }\end{array}$ & Architect \\
\hline Finland & Slovenia & Israel & Butcher & Plumber & Civil Engineer \\
\hline France & Spain & $\begin{array}{l}\text { United States (state- } \\
\text { level) }\end{array}$ & Taxi driver & Nurses ${ }^{\star * *}$ & Lawyer \\
\hline Germany & Sweden & South-Africa & $\begin{array}{l}\text { Driving } \\
\text { instructor }\end{array}$ & & $\begin{array}{l}\text { Real-estate } \\
\text { agent }\end{array}$ \\
\hline Hungary & $\begin{array}{l}\text { Switzerland* } \\
\text { (Basel) }\end{array}$ & & Electrician & & \\
\hline Iceland & United Kingdom & & & & \\
\hline Italy & & & & & \\
\hline
\end{tabular}

Note: $\left({ }^{*}\right)$ For Switzerland (India), the indicator focuses on the occupational entry regulations imposed by the representative Canton of Bern (State of Delhi), but regulations were found to be almost identical in Basel and Bern (Uttar Pradesh and Haryana).

$\left(^{* *}\right)$ Data for Canada could not be validated by Canadian authorities.

$\left.{ }^{(* *}\right)$ Indicator results for nurses are separately described in Box 2 and are not included in the indicator results discussed in Section 3.

15. The overall structure of the indicators is illustrated in Figure 1. At the most aggregate level, the indicator differentiates between three types of occupational regulations: (A) licensing, $(B)$ a situation in

\footnotetext{
${ }^{8}$ http://www.oecd.org/economy/growth/occupational-licensing-and-productivity

${ }^{9}$ Where market expectations and public acceptance play an important role, private initiatives such as the use of certificates and accreditation schemes could be a necessary feature though, impeding market access for non-certified professionals.
} 
which only the manager/supervisor requires a license, and (C) certification. Each type of regulation is characterised by a specific set of legal requirements (or the absence thereof) that determine their regulatory intensity, as described here below.

A. Licensing: describes a situation in which each individual has to obtain the authorisation from a competent national authority or a professional association before they are legally permitted to use the protected title and carry out the activities reserved by a specific occupation. Typically, the authorisation to practice is awarded by satisfying minimum human capital requirements (e.g. education, exams, practical work experience).

B. License only for a supervisor: applies to a situation where professionals can exert the regulated activity as long as they do so under the supervision of one fully licensed professional. For example, electricians in Belgium are authorized to carry out electrical work without holding a license provided that they are under a licensed person's effective and permanent control. Where this applies, the indicator measures the entry requirements applying to the manager, but discounts the overall score by $30 \%$, since this form of regulation is expected to pose lesser burdens on entry, yet it would be misleading to assume that entry is entirely unregulated. If both the manager and her employees are subject to OER (even though they might be of different intensity), the level of regulation assessed by the indicator refers to that of the employee. While such cases can often easily be distinguished, the analysis is more complicated when the share of self-employed is high. Regulations for taxi drivers, for instance, often differ between individuals with a taxi business and those that are employed for a taxi business.

C. Certification: refers to a situation in which professionals voluntarily choose to be certified by a third party so as to use a legally protected title. Because no specific reserved activities exist, however, professionals are not required to obtain the authorisation to practice from a national authority/professional association. Given that certification schemes are voluntary, thus not preventing anyone from practising in the absence of certification, the overall score of the indicator is discounted by $50 \%$.

16. Regulatory barriers are assessed along three areas of regulations: (I) administrative burdens, (II) qualification requirements and (III) mobility restrictions. If regulatory burdens are identified in any of the three areas of regulations (Step 1+2, Figure 2), the professions is considered regulated by the indicator, according to the relevant type of regulation (Step 3).

I. Administrative burdens: This dimension captures the limitations and procedural hurdles set on obtaining the legal authorisation to practice, including (i) territorial restrictions, i.e. whether professionals can only work within certain parts of the jurisdiction under consideration (a country or in the case of the US and Canada a state or province) as is frequently the case for taxi drivers, (ii) restrictions on the total number of authorisations granted, and (iii) registration requirements of professional associations (see Box 1).

II. Qualification requirements: This dimension records the requirements related to the education acquired by professionals prior to entering their occupation. It notably includes (i) the number of possible pathways to obtain the qualification, assuming that a higher number attracts potential wider set of professionals with diverse backgrounds, allowing for more diversity and innovation; (ii) whether a university or vocational course is mandatory, which could discourage potential candidates from choosing a certain occupation; and (iii) the presence of mandatory practice and state exams, again, posing additional burdens on the potential worker.

III. Mobility restrictions: This dimension includes barriers to labour mobility between jurisdictions (countries, US states, or Canadian provinces), by (i) accounting for the presence of transparent recognition mechanisms of out-of-jurisdiction qualifications; (ii) the obligation for out-of-jurisdiction workers to take a local exam before practising; and (iii) the necessity to demonstrate citizenship or a specific nationality. So long as the jurisdiction has a transparent recognition mechanism in place 
for at least one jurisdiction, and equivalently refrains from imposing a local exam, or accepts citizens from at least one other jurisdiction, the indicator value is set to minimum.

17. In order to simplify cross-country and cross-state comparisons, the final indicator is scaled to take values between 0 (no regulation) and 6 (fully regulated). To this end, we aggregate the scores of each subindicator using equal weights, before we discount the total value based on the prevalent type of regulation (i.e. multiplied by 0.7 or 0.5 if only a supervisor is required to obtain a license or in the case of certification, respectively). For Canada and the US, each state or province is given equal weight when aggregating the results to the country-wide indicator. ${ }^{10}$ This specific weighting technique is chosen on transparency grounds and does not reflect the objective importance of each sub-indicator. Detailed information on the construction of the indicator, including the coding of individual answers, is provided in Annex B - Annex D.

Figure 2. Structure of the new OECD Occupational Entry Regulations (OER) indicator

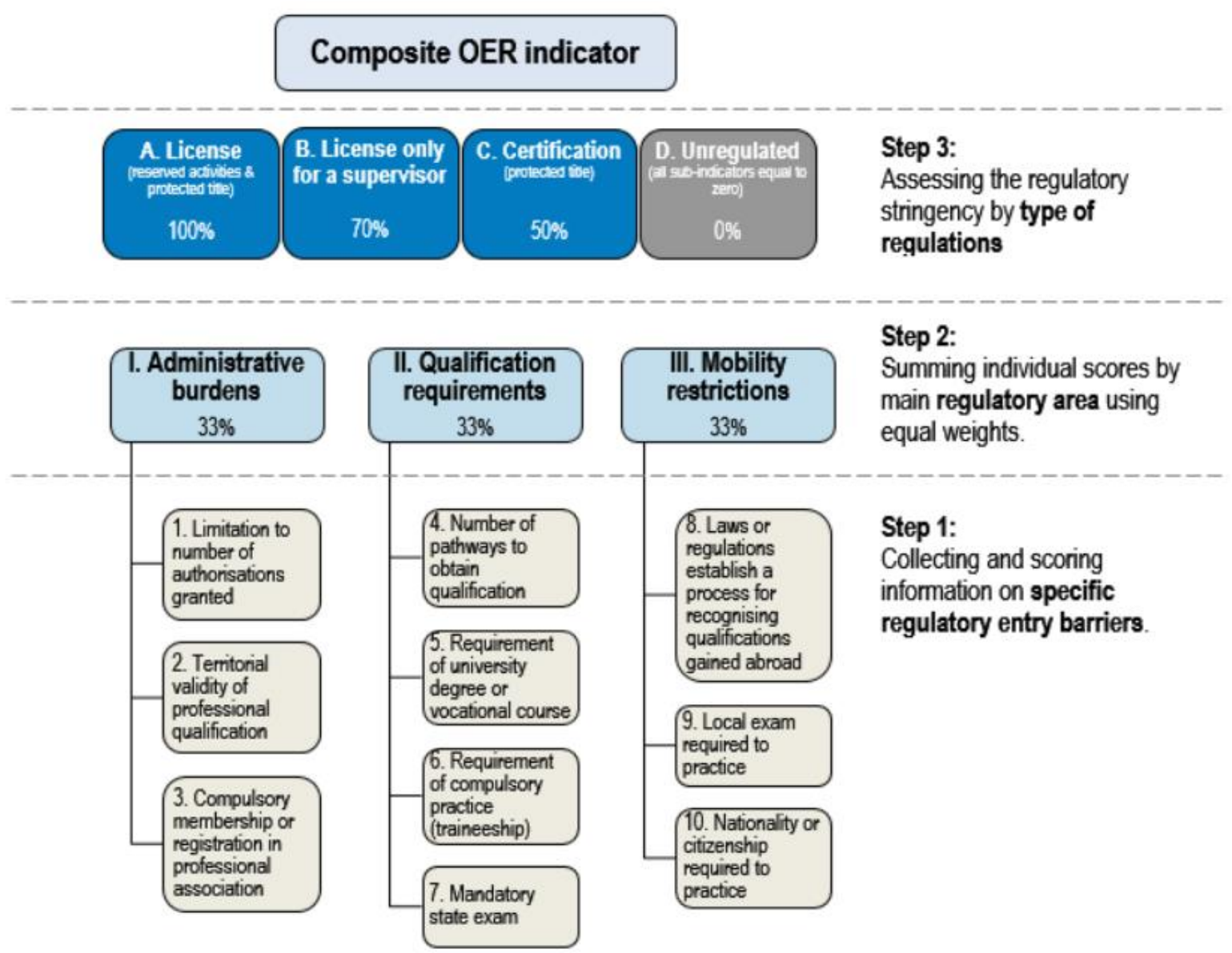

\subsection{Limitations and interpretative pitfalls}

18. A consequence of the indicator's broad coverage of services and jurisdictions is that several limitations had to be embraced. For one, the indicator ignores cultural or political attitudes towards the role of the state in the economy that may affect regulatory approaches in personal and professional services. Pagliero (2019), for instance, finds that the prevalence of licensing is negatively correlated with regulations

\footnotetext{
${ }^{10}$ For reference, Figure A.2 also illustrates indicator outcomes for Europe, Canada and the US at the country, state and province level using population-weighted OER levels.
} 
of employment relations and the generosity of social security systems (in terms of old-age pensions, sickness and health coverage, and unemployment insurance), while Kleiner and Krueger (2010) suggest that over the past decades, occupational licensing might have become a substitute for unions. In a similar vein, some legal systems might rely more intensively on insurance or litigation, rather than ex-ante checks of service providers, thus explaining higher level of regulations captured by the OER.

19. In the absence of comparable data, the indicator also ignores differences in the quality of the services provided by professionals. Quality maintenance has indeed been a common justification for occupational regulations in general, and licensing in particular. However, there is very little empirical evidence of a positive link between the stringency of regulations and the quality of services (Caroll and Gaston, 1981; Koumenta et al., 2019; Kleiner, 2017; Kleiner and Kudrle, 2000, Powell and Vorotnikov, 2015).

20. Several aspects of occupational regulations also had to be omitted from the indicator when their procurement proved too difficult, or when their relevance was limited to specific regions or professions. These include the price of a license; limits to the fees that can be charged by the profession; mandatory insurance and license renewal requirements; the existence of 'grandfathering rights', i.e. information on whether incumbents were allowed to bypass the requirements posed by the regulation at the time it was introduced; the impediments posed by criminal records; the treatment of military spouses or veterans; and the regulatory power of professional associations. Where such regulations play a crucial role for market entry, the indicator might underestimate the stringency of occupational entry regulations. ${ }^{11}$

21. Another important dimension that could not be covered due to the scarcity of reliable data is the number of reserved activities associated with each profession or occupation. For example, some countries differentiate between the profession of accountants (who typically prepare financial accounts for firms, handle payrolls, reconcile firms' books at end of the financial year, and file in tax returns) and auditors (who perform statutory auditing activities), while other countries combine all activities in one profession. In the absence of readily-available cross-jurisdiction data on reserved activities in each occupation, we assume for simplicity that the reserved activities listed in Table B.1 are equal in all jurisdictions under review. Indicator values might therefore mismeasure the actual stringency of regulations in jurisdictions where reserved activities with different entry requirements are bundled.

22. Lastly, the indicator provides no indication of what should be the "optimal" level of regulation nor does it pass any judgement on which specific measures might be usefully kept in place and which ones a country might wish to consider for possible reform or removal. Rather, the indicator's purpose lies in its function as a benchmarking tool, informing policy makers where home regulations deviate from those observed in other countries. Especially in countries that share the same level of development and similar institutional structures this could put a spotlight on regulatory areas that might need to be reviewed.

\footnotetext{
${ }^{11}$ Moreover, several of the occupations under analysis are performed by self-employed workers, who might have to comply with additional legal requirements relating to business permits (e.g. hygiene checks) or fall under specific conduct regulations (e.g. restrictions on the legal form of the business, on advertising, or inter-professional cooperation), as illustrated by the OECD Product Market Regulations database (see Vitale et al., forthcoming). However, these factors are likely to play a minor role for personal services.
} 


\section{Box 1. The complex role of professional associations}

The principal raison d'être for a professional association (also called professional body, professional organisation or professional society) is to represent the interests of professional practitioners. However, professional associations sometimes also cover the regulatory function over its members. In this case, incumbent practitioners have a dual mandate of defending their members' (and their own) interests, while controlling all access to and conduct within a certain occupation, e.g. by establishing criteria that limit entry rates into their occupation.

Several scholars and competition authorities alike judge this type of institutional setting as welfarereducing, given the inevitable tension between the promotion of professional interests and the interests of the wider public (Grajzl and Murrell, 2007). In this context, the US Supreme Court stated that "[t]here is no doubt that the members of such associations often have economic incentives to restrain competition and that the product standards set by such associations have a serious potential for anticompetitive harm." (Allied Tube v. Indian Head, Inc., 486 U.S. 492, 1988). This tension is further exacerbated when the professional association, in addition to exercising a regulatory function, also holds the disciplinary function of its members. In this case, its members might be incentivised to protect themselves from complaints to the detriment of their clients and, more broadly, the quality of their service (OECD, 2018).

Against this background, OECD (2018) recommends "separating the regulatory function from the representative function for self-regulated professional associations [...] either through the creation of an over-arching independent supervisory body by sector or trade - or through the creation of a supervisory body within the current professional order with the necessary "Chinese walls"." The board of the supervisory body should be composed of professional representatives but also of "experienced individuals from other regulators or organisations, representatives of consumer organisations and academia" so as to encourage an unbiased regulation of the sector. In line with this idea, the 2007 Legal Services Act of the United Kingdom, for instance, led to the creation of a supervisory Legal Services Board (LSB) charged with regulating the profession, while the respective professional association has kept its representative function. Similarly, most professions in the United States are regulated by professional boards regulating their practice and licensure, while few occupations further defend their interests through professional associations (e.g. the American Bar Association).

Due to data limitations, the OER indicator only captures if professionals are obliged to register with a professional association, assuming that this poses an additional administrative and potential financial burden.

\section{Cross-country differences in OER}

\subsection{A first glance at the data}

23. We illustrate the average OER scores for the full indicator and each of its subcomponents by profession and country (Figure 3 and Figure 4), the incidence of each type of regulation (Figure 5) and the cross-country (or cross-state) variability of regulations by occupation (Figure 6). Altogether, these graphs highlight the following stylized facts:

- As expected, the average regulatory stringency is lower in personal services than in professional services, although, within the personal service category, taxis, driving instructors and electricians are typically more regulated than all other crafts. In fact, entry into the crafts professions (aesthetician, bakers, butchers, painter, plumber) is often unregulated (Table 2, Figure 3 and 4). 
- For some professions, including taxi drivers, driving instructors, and professional services, mobility restrictions are high even for professionals moving between states in the US, provinces in Canada, or countries in the European sample. This result is especially surprising given the various policy initiatives aimed at facilitating the movement of professionals within these economic areas, which are discussed in section 3.1.

- The regulatory variance of personal services amid European countries, US states, and Canadian provinces is wide, suggesting the need for better integration of these services in all three economic areas (Figure 6). For instance, while Nordic countries and Germany (or Maryland in the US and British Columbia in Canada) usually impose few or no entry regulations on professional services, Italy (or Nevada in the US and Manitoba in Canada) typically leads the ranking of occupational entry regulations (see Annex $G$ ).

- Occupational regulations typically take the form of licensing requirements, the most stringent form of regulation (Figure 5). Only very few countries, most of which are in Europe, allow for alternative schemes, including certification.

- The difference in OER levels between personal and professional services is particularly stark in India and South Africa (see section 3.2). One explanation for this observation might lie in the size of the informal sector, which might make it difficult to regulate, low-skilled personal services. At the same time, the quest for signalling the quality of professional services (e.g. lawyer, accountants) might explain the regulatory levels much above that of the other countries in this sample.

\subsubsection{Personal services}

24. The average level of regulation in personal services, Figure 3 (Panel A) broadly displays the same patterns across all countries: while most crafts (i.e. aestheticians, butcher, baker, hairdressers, painter/decorators, plumber) tend to be unregulated, individuals working as taxi drivers, driving instructors and electricians face significant occupational entry regulations. ${ }^{12}$ For instance, taxi drivers and driving instructors typically need to comply with qualification requirements to demonstrate local knowledge. This also explains the difficulty of transferring from one jurisdiction to another, and therefore, the presence of mobility restrictions. Taxi drivers in our European sample are further restricted in the territorial validity of their license within their jurisdiction, contributing to the high OER score recorded in their occupation ${ }^{13,14}$ Similar, though slightly lower, regulatory burdens apply to electricians. Compared with other crafts, the level of regulation for electricians stands out as particularly high, perhaps because electricians often carry out tasks, which could expose themselves and their customers to serious safety risks, if poorly performed.

25. Comparing personal service regulation across countries suggests two interesting findings. First, in the case of electricians, plumbers, hairdressers and aestheticians, the average level of regulation is considerably higher in Canada and the United States than in Europe, Israel or India. As shown by Figure 5 , this notably relates to the type of regulation applied: many of the European countries allow professionals to work without a license, provided they do so under the supervision of a licensed professional, while the same option is only available in a handful of US States. Second, European regulations are very similar across personal services, given that they are often bundled in trade and crafts codes, whereas US and

\footnotetext{
12 Nurses, which display a comparable level of regulation, are separately assessed in Box 2, as the justification for OER in the health care sector differs from other sectors, in that it seeks to prevent potentially health threatening professional misbehaviour.

13 Similar regulations restricting the quantity of businesses are notably known to exist in the pharmaceutical sector and for notaries, as several countries fix the maximum number of pharmacies or notaries that can be located in a given area, based on population ratios and the distance to other pharmacies (Vitale, 2014).

${ }^{14}$ However, the increasing entry by other ride-hailing providers might have reduced this binding constraint over the recent past.
} 
Canadian regulations are more diverse: while butchers and bakers are entirely unregulated, for instance, hairdressers and aestheticians are subject to relatively high entry barriers, possibly reflecting a tradition of regulating the provision of services rather than of goods (with goods regulated in product standards).

\subsubsection{Professional services}

26. Average entry barriers into professional services are higher than for personal services in all regions (Figure 3, Panel B and Figure 4, Panel B). Such barriers are especially apparent for lawyers, who typically face all regulations reflected by the sub-indicators, e.g. qualification requirements, mobility barriers (i.e. necessity to take a local exam in order to practice), and administrative burdens (e.g. the obligation to register in professional associations). While the obligation to register with a professional association usually also holds for other professional services in Europe, lawyers are the only occupation among the ones we consider that also require registration in the US and in Canada.

27. Turning to accountants, architects, civil engineers and real estate agents, regulations tend to be relatively more lenient, although Figure 3 and 4 (Panel B) identify important differences between and within countries. One interesting example with regards to within country-differences is India, as the country refrains from imposing any regulation on civil engineers, but places especially high regulatory burdens on architects and accountants, even in the form of nationality requirements. Across countries, accountants display the largest regulatory dispersion: while they are (almost) entirely unregulated in Israel and the US, European countries, Canada and India restrict entry into this occupation using a variety of regulatory tools. OECD (2018) suggests that if one separately considers the countries where accountants and auditors are a single profession (e.g. Austria, Italy and Canada) and those where they are two separate ones (e.g. France, Germany, Hungary, and the UK) the level of the barriers to entry and conduct imposed on these professionals still varies significantly across these two groups. Similarly, one could expect entry regulations for real-estate agents to be higher in countries where the profession shares conveyancing activities with lawyers and/or notaries, but some countries record high indicator values even though they fall into the other group of countries (e.g. Belgium or South Africa).

\subsubsection{Dispersion of approaches within broad economic areas}

28. Figure 6 suggests that all three economic areas - Europe, Canada and the US - are characterised by a large variety of regulatory approaches. Nordic countries and Germany (or Maryland in the US and British Columbia in Canada), for instance, usually impose few or no entry regulations on professional services, whereas Italy (or Nevada in the US and Manitoba in Canada) often lead the ranking of occupational entry regulations (see Annex G). While the average difference between the 25th and 75th percentile in personal services is especially wide for personal services in Canada, the reverse situation can be observed in the professional services sector in Europe. Here, US states and Canadian provinces display almost no variation, except for lawyers, while European countries apply regulations ranging on a scale from 0 to 4 . Despite the numerous attempts to set common standards within federal countries and economic areas (see section 3.1), these findings suggest an unfinished economic integration agenda that curbs in critical ways labour mobility across geographic areas and occupations. 
Table 2. Summary statistics OER indicator by profession

\begin{tabular}{|c|c|c|c|c|c|c|c|c|c|}
\hline & Aesthetician & Baker & Butcher & $\begin{array}{c}\text { Driving } \\
\text { Instructor }\end{array}$ & Electrician & $\begin{array}{c}\text { Hairdresse } \\
r\end{array}$ & $\begin{array}{l}\text { Painter- } \\
\text { decorator }\end{array}$ & Plumber & Taxi driver \\
\hline Sample average & 0.3799 & 0.3158 & 0.2929 & 1.4283 & 0.9236 & 0.4457 & 0.3429 & 0.5946 & 2.5468 \\
\hline $\begin{array}{l}\text { Average of } 5 \\
\text { highest countries }\end{array}$ & 1.1695 & 1.1933 & 1.0883 & 2.215 & 1.7694 & 1.2694 & 0.1567 & 1.5633 & 3.6 \\
\hline $\begin{array}{l}\text { Average } 5 \text { lowest } \\
\text { countries }\end{array}$ & 0 & 0 & 0 & 0.8333 & 0.0850 & 0 & 0 & 0 & 1.6105 \\
\hline Variance & 0.2567 & 0.3132 & 0.2605 & 0.3066 & 0.4480 & 0.2855 & 0.2797 & 0.4537 & 0.6355 \\
\hline
\end{tabular}

\begin{tabular}{lccccc}
\hline & Accountant & Architect & Civil Engineer & Lawyer & $\begin{array}{c}\text { Real-estate } \\
\text { agent }\end{array}$ \\
\hline $\begin{array}{l}\text { Sample average } \\
\begin{array}{l}\text { Average of } 5 \text { highest } \\
\text { countries }\end{array}\end{array}$ & 1.4580 & 1.8862 & 1.3275 & 2.8025 & 1.2063 \\
$\begin{array}{l}\text { Average } 5 \text { lowest } \\
\text { countries }\end{array}$ & 3.3 & 3.1667 & 2.783 & 3.75 & 2.7167 \\
Variance & 0 & 0.3583 & 0 & 1.6624 & 0 \\
\hline
\end{tabular}

Note: For the US and Canada, unweighted averages are used. An indicator value of 0 indicates the absence of regulations, 6 reflects a fully regulated market.

Figure 3. OER indicator by profession and country group

Panel A: Personal services

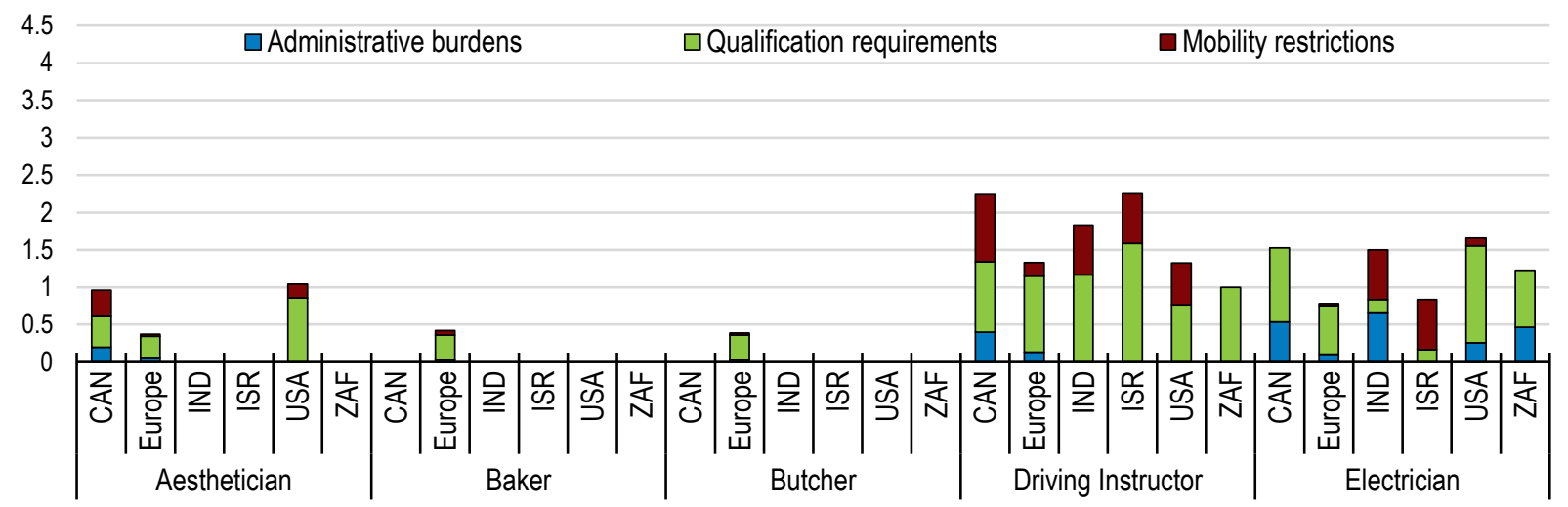

Panel A: Personal services (cont.)

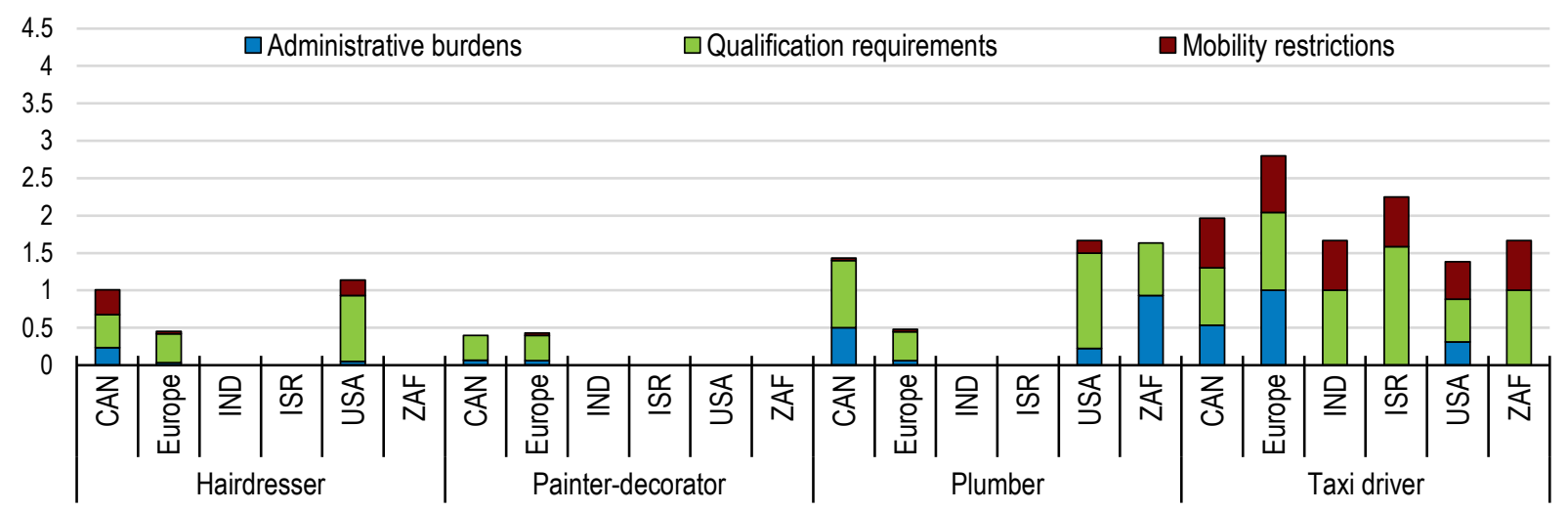




\section{Panel B: Professional services}

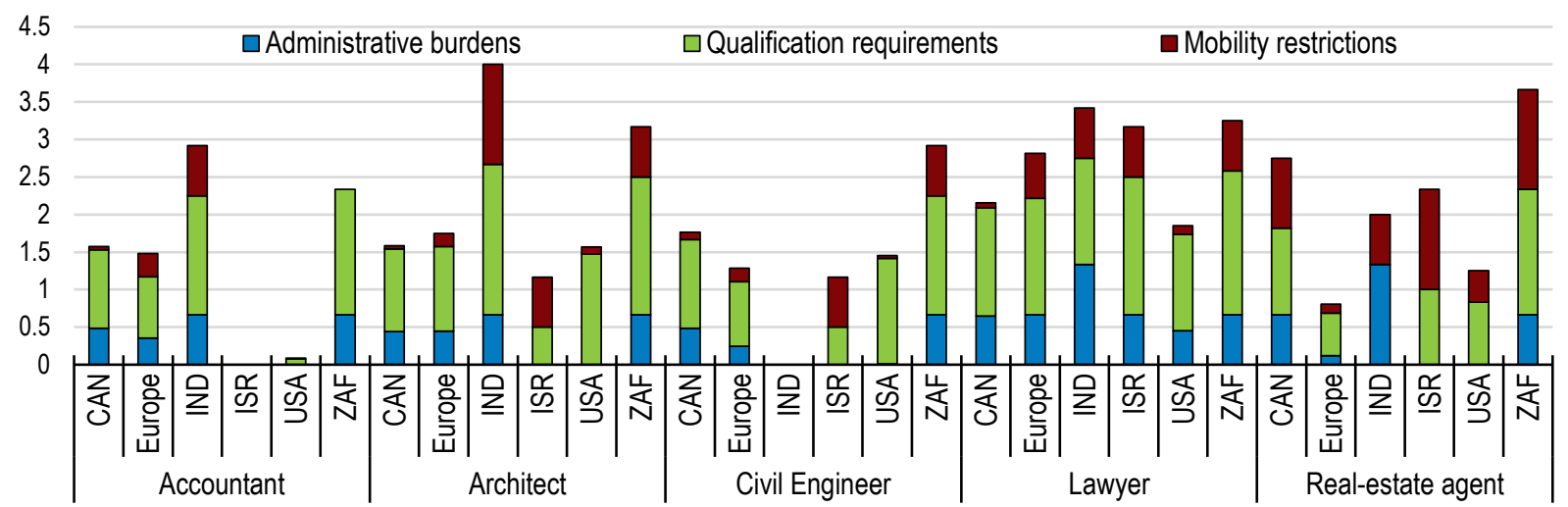

Note: An indicator value of 0 indicates the absence of regulations, 6 reflects a fully regulated market. Regulations for Canada and US are measured at province/state level. The European sample displays the unweighted average of OER levels in Austria, Belgium, Finland, France, Germany, Hungary, Iceland, Italy, Poland, Portugal, Slovenia, Spain, Sweden, Switzerland, and the United Kingdom, while regulations for Canada and US represent the unweighted average of all province/state level. Country abbreviations can be found in Annex E.

Source: OECD OER database. To download this graph, please visit https://bit.ly/2w4MR2X

\section{Figure 4. Total OER indicator by country}

\section{Panel A: Personal services}

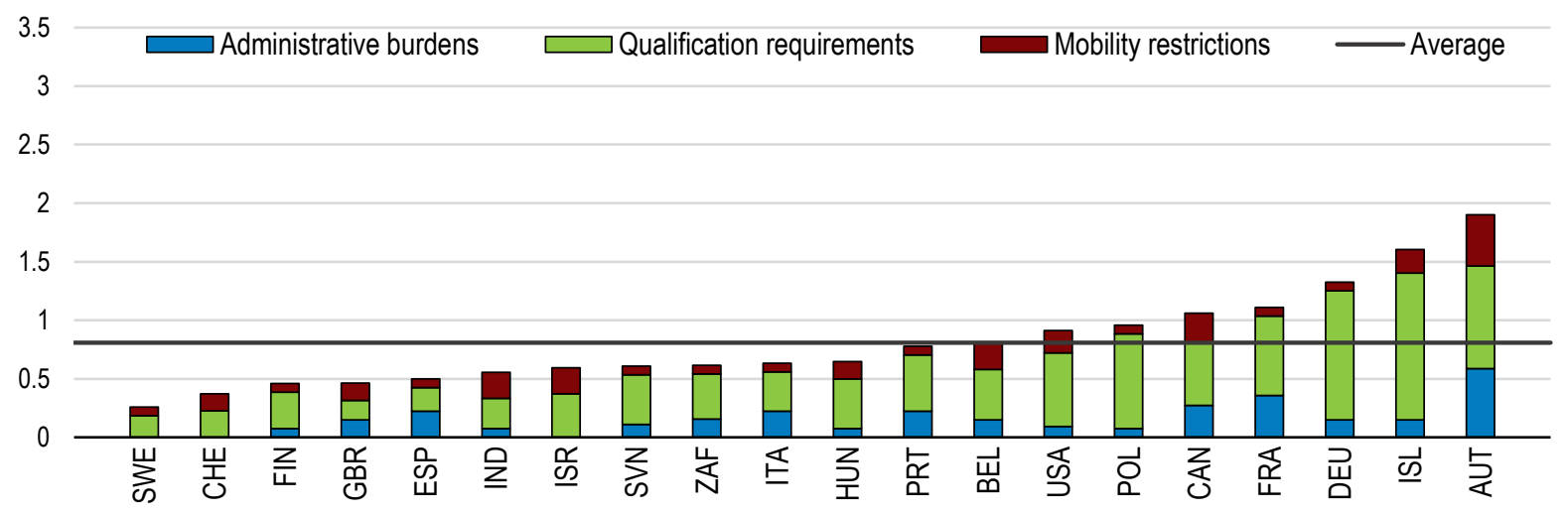

Panel B: Professional services

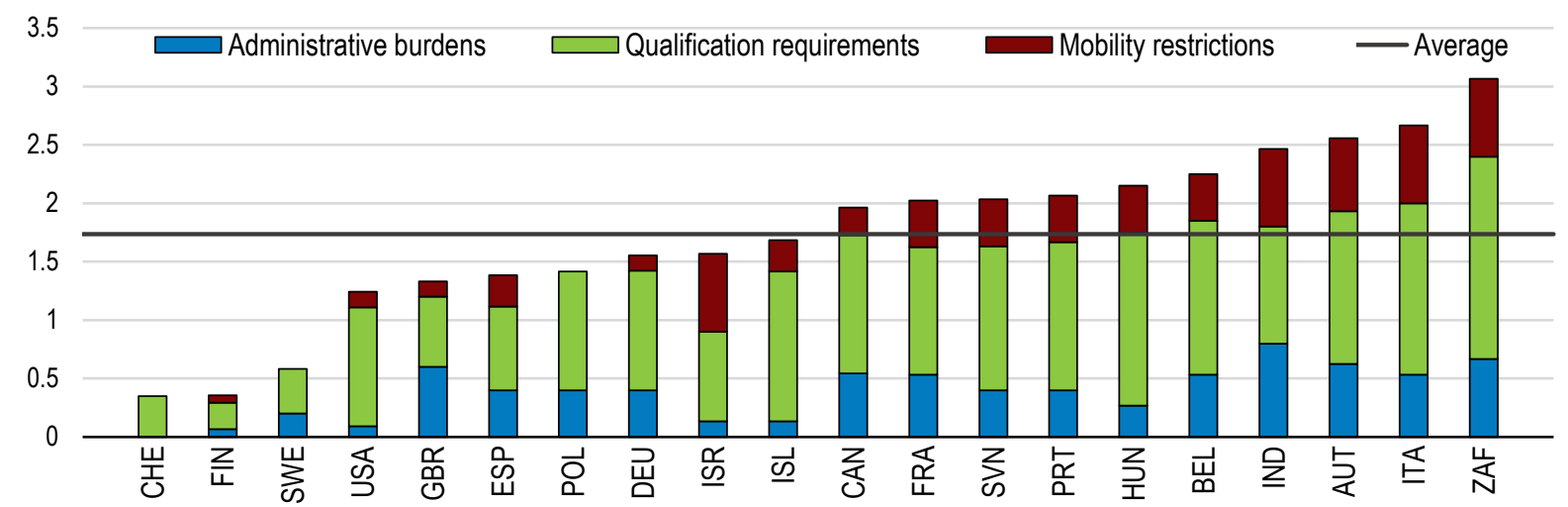

Note: An indicator value of 0 indicates the absence of regulations, 6 reflects a fully regulated market. Regulations for Canada and US represent the unweighted average of province/state level regulations. Country abbreviations can be found in Annex E.

Source: OECD OER database. To download this graph, please visit https://bit.ly/2w4MR2X 


\section{Figure 5. Licensing systems dominate occupational regulations}

\section{Percentage of occupations by country group}

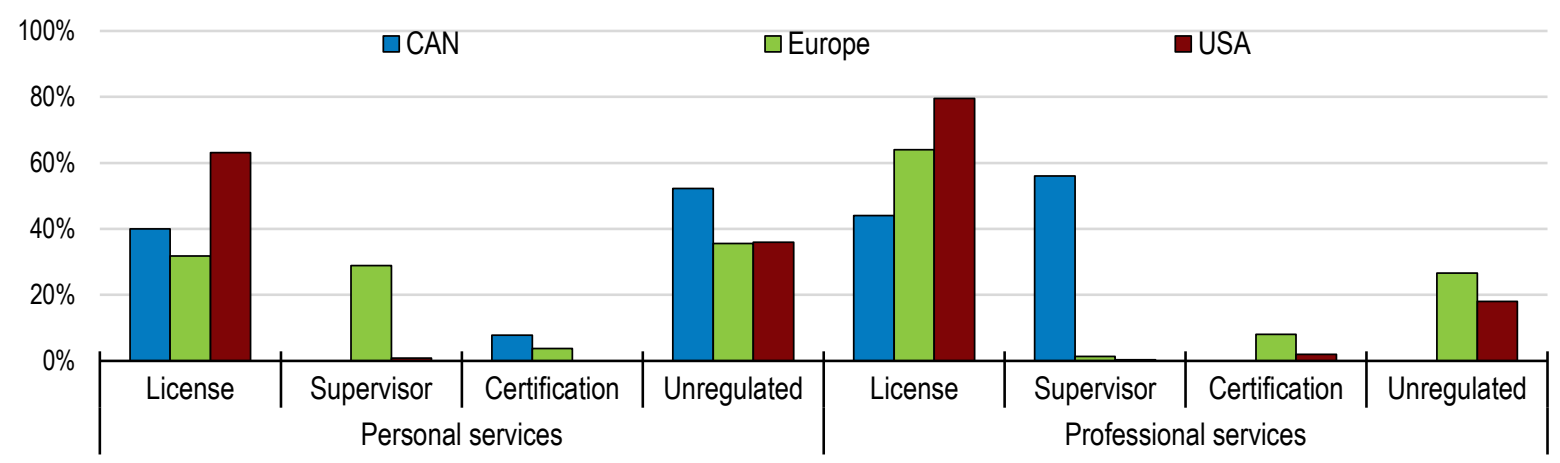

Note: Personal services include aestheticians, bakers, butchers, driving instructors, electricians, hairdressers, painters, plumbers and taxi drivers; professional services include accountants, architects, civil engineers, lawyers and real-estate agents. The European sample includes Austria, Belgium, Finland, France, Germany, Hungary, Iceland, Italy, Poland, Portugal, Slovenia, Spain, Sweden, Switzerland, and the United Kingdom.

Source: OECD OER database. To download this graph, please visit https://bit.ly/2w4MR2X

Figure 6. The dispersion of regulatory approaches within economic areas suggests incomplete economic integration

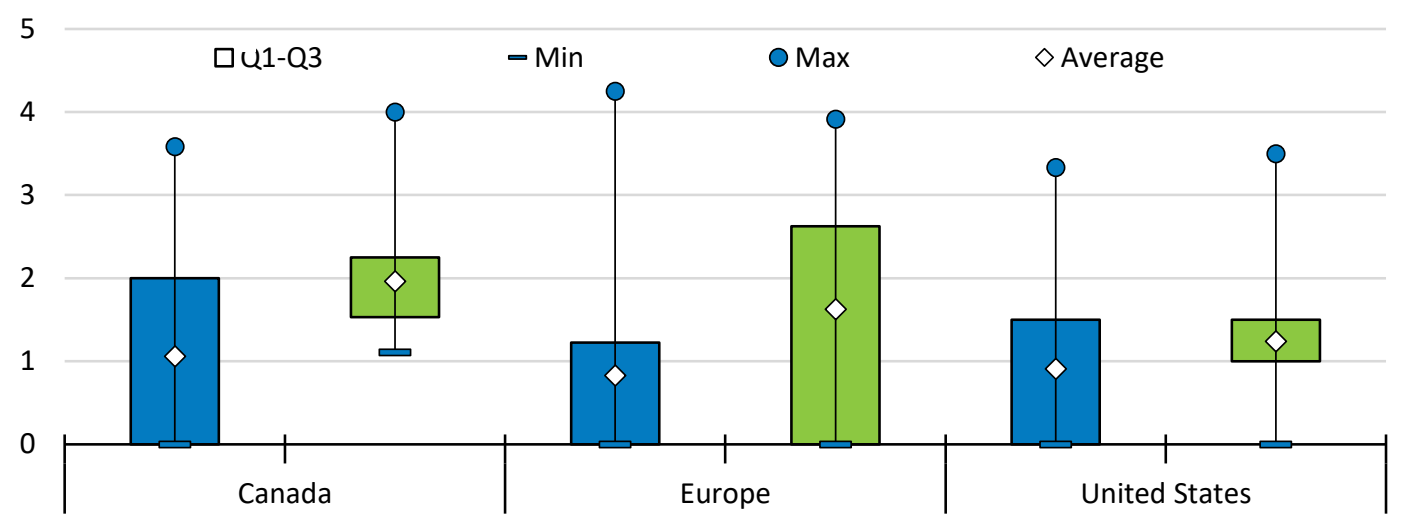

Note: Blue bar refers to personal services (include aestheticians, bakers, butchers, driving instructors, electricians, hairdressers, painters, plumbers and taxi drivers); green bar refers to professional services (accountants, architects, civil engineers, lawyers and real-estate agents). An indicator value of 0 indicates the absence of regulations, 6 reflects a fully regulated market. Regulations for Canada and US are measured at province/state level. The European sample includes Austria, Belgium, Finland, France, Germany, Hungary, Iceland, Italy, Poland, Portugal, Slovenia, Spain, Sweden, Switzerland, and the United Kingdom. Figure A.1. further illustrates cross-country dispersion by occupations.

Source: OECD OER database. To download this graph, please visit https://bit.ly/2w4MR2X 


\section{Box 2. Occupational entry regulations in the health sector - the example of nurses}

More than in any other sector, occupational entry regulations are used in health care services to protect the public from unqualified, incompetent or unsafe providers. Their existence is typically justified by the imbalance of power and knowledge between patients and the health care provider, as patients are often unable to objectively assess the quality of services provided (Aldridge, 2008), and because incompetently performed services can have serious health-threatening consequences. Policy makers thus face the difficult task of adequately protecting consumers while ensuring a sufficiently high supply of skilled professionals.

In this context, the regulation of nurses is of key importance. Many advanced economies are faced with rapid population ageing, and therefore a rapidly increasing demand for health care providers, and notably nurses. To facilitate the efficient allocation of nurses from countries where they are in excess to countries facing shortages within the EU, the European Directive (2013/55/EC) thus introduced an automatic recognition of foreign diplomas for general care nurses and harmonised minimum training requirements. Still, as displayed by Figure 7, regulatory differences between European countries persist and loom large. For instance, while Swedish nurses only have to meet qualification requirements, several other countries further impose significant administrative barriers. In comparison to the EU, average US regulations are more lenient and confined to qualification requirements (notably due to the "Nurse Licensure Compact" allowing nurses to practice in most other US states), while Israel and India impose strict mobility barriers.

\section{Figure 7. Cross-country variation in OER of general care nurses}

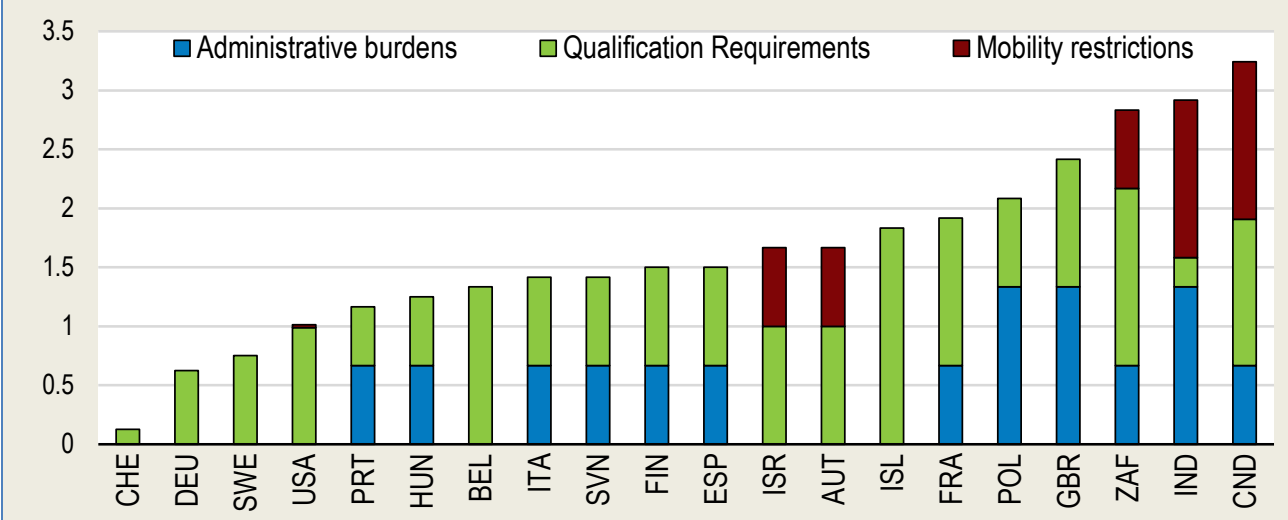

Note: An indicator value of 0 indicates the absence of regulations, 6 reflects a fully regulated market. Regulations for Canada and US represent the unweighted average of province/state level regulations.

Source: OECD OER database. To download this graph, please visit https://bit.ly/2w4MR2X

\subsection{Detailed results - OECD countries ${ }^{15}$}

\subsubsection{Europe}

29. European statistics show that in 2015 , an average of $22 \%$ of the workforce in the EU was licensed (see Figure 8). This average figures masks wide cross country-differences in the share of employment in

\footnotetext{
${ }^{15}$ A list of country-specific literature can be found in Annex C of Bambalaite et al. (2020).
} 
regulated professions, which in turn are correlated with the stringency of OER. Countries recording a higher OER indicator value, e.g. Germany or Hungary, also figure at the higher end of the ranking, while countries with lower OER values, such as Denmark or Sweden, report a lower share of licensed workers in their overall workforce. Since the graph omits information on the share of certified workers due to a lack of data, the actual percentage of regulated workers might be even higher.

\section{Figure 8. The share of the workforce holding an occupational license in the EU (2015)}

Percentage of licensed workers (\%)

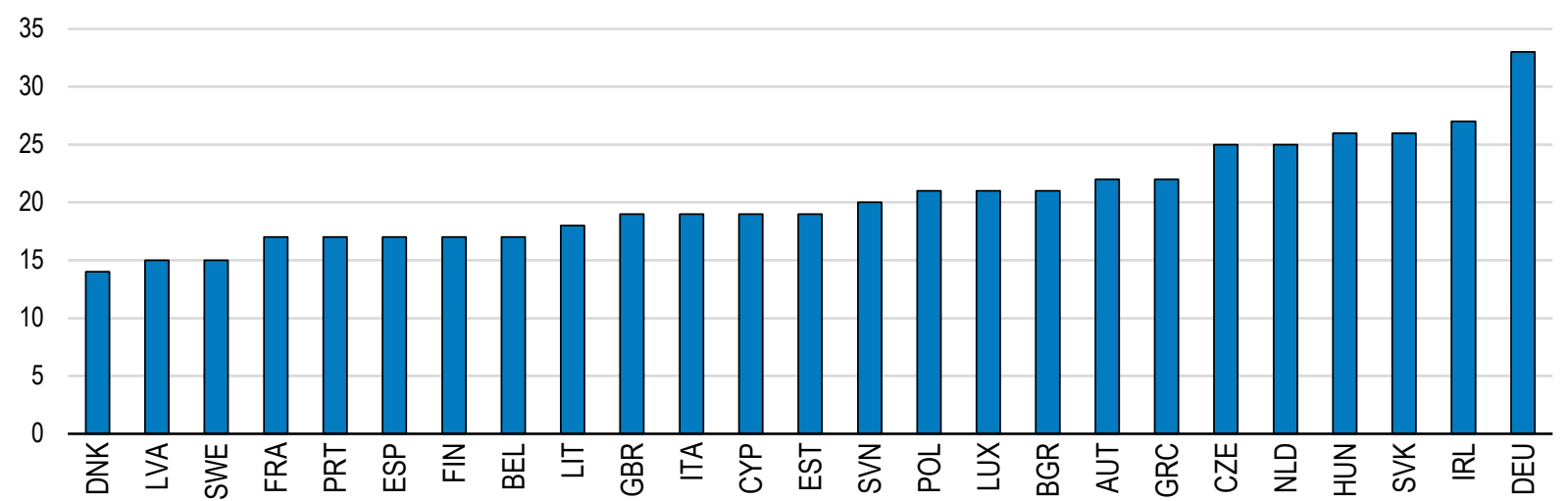

Note: Based on information retrieved from the EU Survey of Regulated Occupations. Country abbreviations can be found in Annex E. Source: Koumenta and Pagliero (2017). To download this graph, please visit https://bit.ly/2w4MR2X

30. The European countries covered by the OER indicator differ in both the stringency and the composition of regulations. In personal services, average indicator values can be as low as 0.3 (Sweden) or as high as 1.9 (Austria), with values differing by up to 3.6 units across services within countries (e.g. for Belgium) (Figure 9, Panel A). Similar differences are found for professional services, though at the upper bound average levels of regulation are typically higher than in personal services (2.7 in Italy). The lion's share of occupational entry regulations falls on qualification requirements (Figure 10), as administrative requirements are often confined to the mandatory registration in professional bodies and a variety of EC directives suppressed mobility restrictions within the single market.

31. Regulations also display high variation within the two sets of personal and professional services. For instance, while the average level of regulations in personal services is similar for all crafts (often due to the presence of craftsman codes, e.g. the "code de l'artisanat" in France, or the "Handwerksordnung" in Austria and Germany), electricians, driving instructors, and taxi drivers are typically subject to much stricter OER, likely due to the safety risks associated with these three professions. What is less obvious, however, are the striking differences in the pattern of regulations imposed on professional services, where countries at the lower end of the ranking not only score significantly lower average stringency, but also display a much lower variability of regulation across the five professions covered by the OER.

32. The stark regulatory differences across members of European Union are surprising because the EU has a long history of trying to facilitate the recognition of professional qualifications. Over the 19641982 period, the Council adopted the first directives aimed at the recognition of professional experience for craftsmen. This was closely followed over the 1975-1985 period by the first directives on the recognition of diplomas for doctors, general care nurses, pharmacists, midwives, dentists, veterinarians and architects, which provided for automatic recognition coupled with a harmonisation of minimum requirements for training. Other professions were also covered by general directives on the recognition of diplomas, with a possibility of measures to compensate substantial differences in training between the home and the host Member State (as from Directive 89/48/EEC). In addition, automatic recognition of home-state professional 
titles regime was introduced by the Directives 77/249/EEC (services) and 98/5/EC (establishment) in the specific case of lawyers.

33. Reform efforts culminated in the 2005 adoption of the Professional Qualifications Directive (2005/36/EC) (with amendments in 2013, by 2013/55/EU), consolidating all directives (with the exception of the Lawyers' directives) into one legal instrument. The Directive sets clearly defined principles and processes for professional qualification recognition, allowing professionals from EU member states to benefit from simplified recognition procedures which presumably reduce mobility costs. For professionals from outside of the EU/EEA, rules tend to be stricter since EU countries normally set their own discretionary recognition systems.

Figure 9. Within-country variance of regulatory stringency across occupations: Europe

Panel A: Personal services

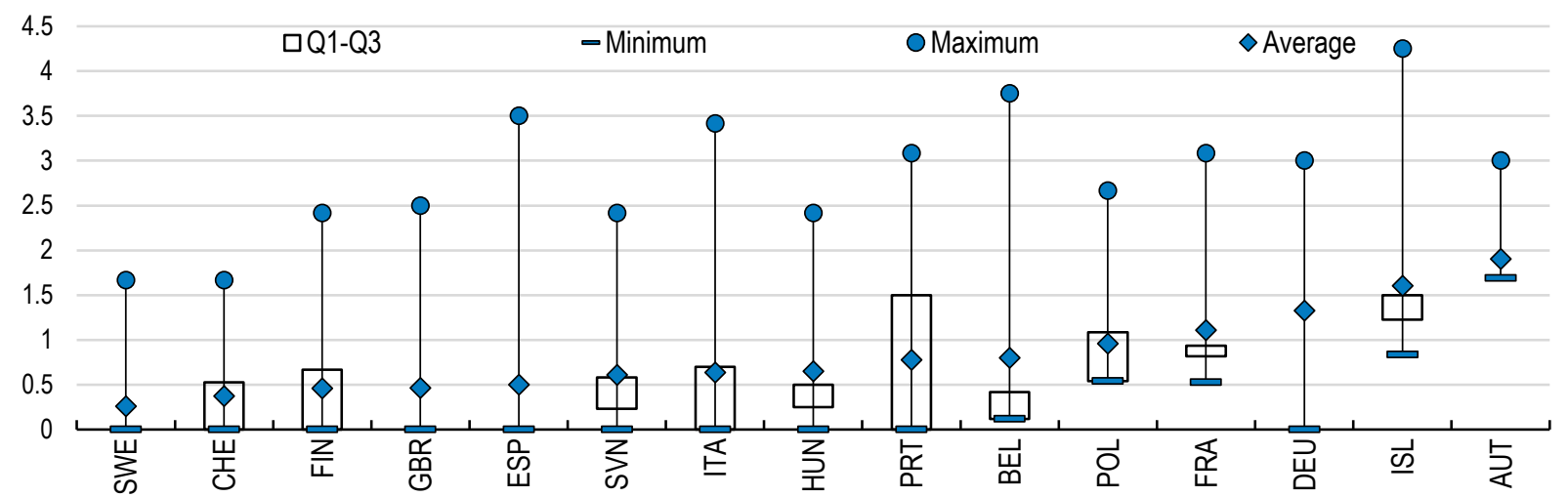

Panel B: Professional services

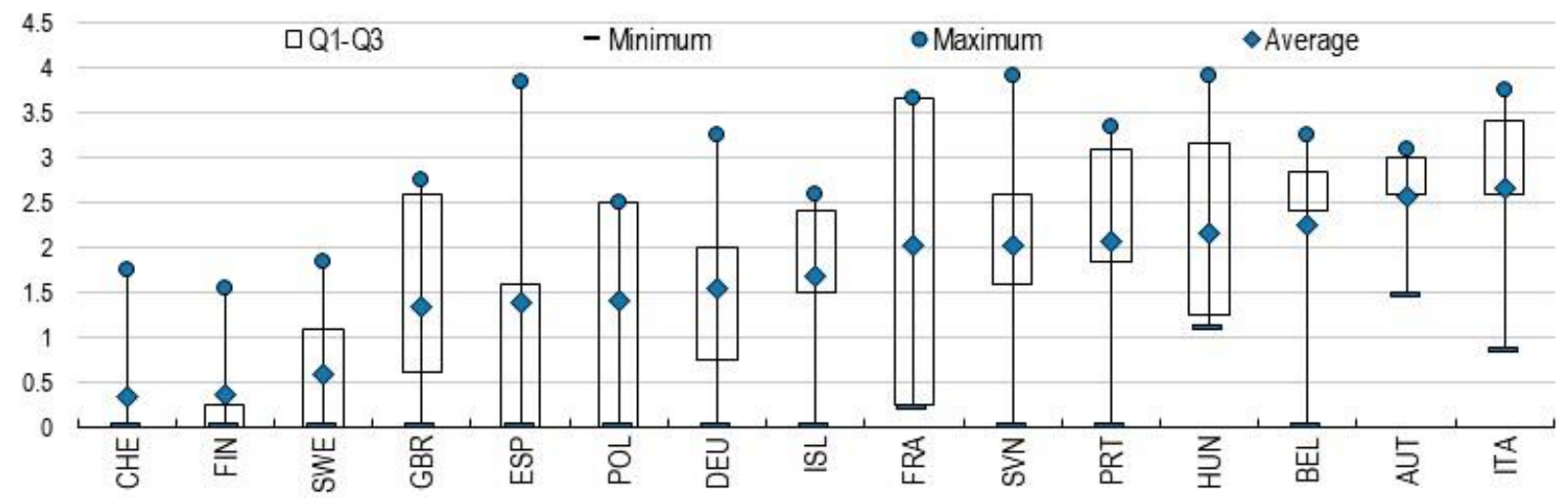

Note: An indicator value of 0 indicates the absence of regulations, 6 reflects a fully regulated market. Country abbreviations can be found in Annex E.

Source: OECD OER database. To download this graph, please visit https://bit.ly/2w4MR2X 


\section{Figure 10. Composition of average regulation by sub-indicator: Europe}

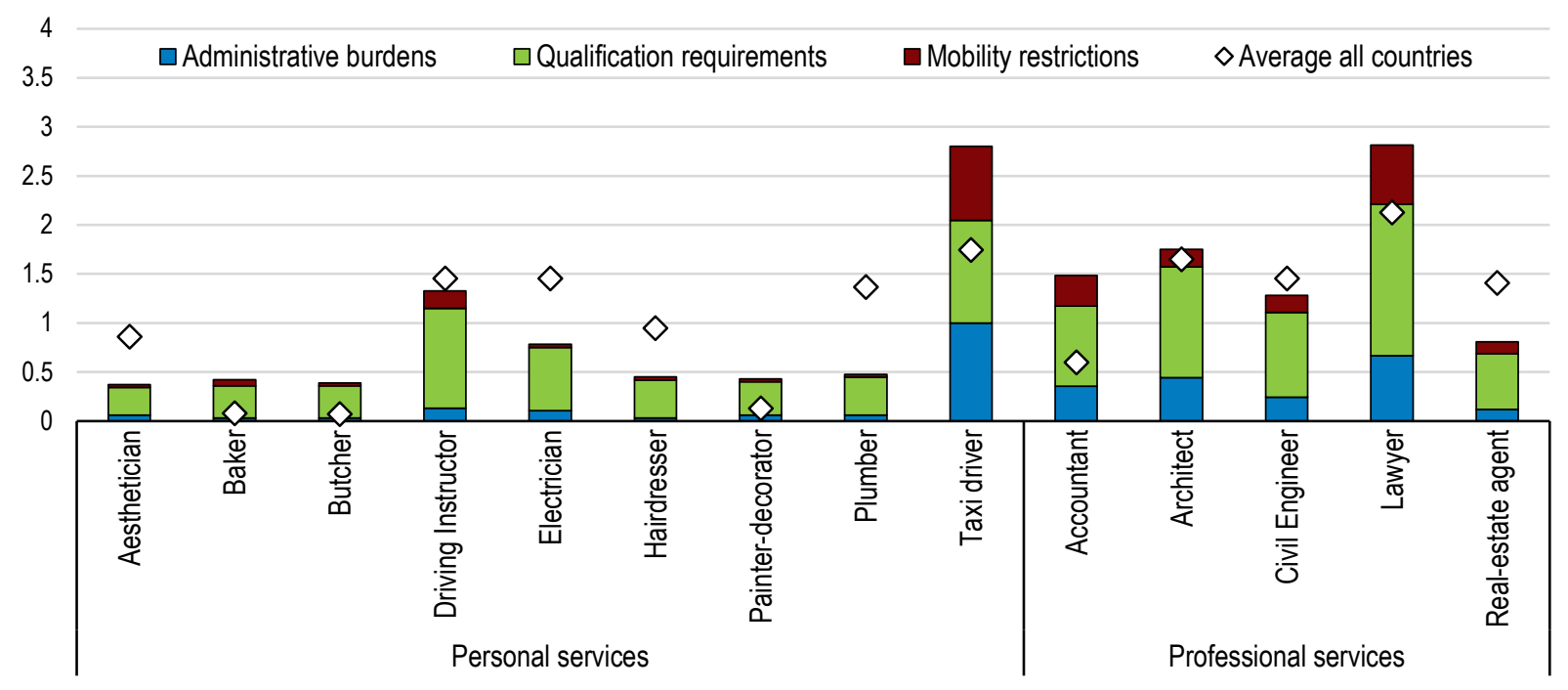

Note: An indicator value of 0 indicates the absence of regulations, 6 reflects a fully regulated market. The graph displays unweighted averages of OER levels in Austria, Belgium, Finland, France, Germany, Hungary, Iceland, Italy, Poland, Portugal, Slovenia, Spain, Sweden, Switzerland, and the United Kingdom.

Source: OECD OER database. To download this graph, please visit https://bit.ly/2w4MR2X

34. Despite the simplified recognition of qualifications procedures, differences in other regulatory requirements (beyond qualifications) across EU countries still raise important barriers to mobility. The Member States thus agreed to undertake a transparency and mutual evaluation exercise in 2014-2016 to compare their regulatory approaches and to simplify, where necessary, their national professional regulation. In addition, the European Commission also provided guidance to Member States on reform recommendations in the existing regulation of professional services in 2017 (COM/2016/820 final), since the level of ambition and the quality of analysis differed greatly across Member States. Lastly, 2018 saw the adoption of the Proportionality test directive (EU 2018/958) obliging Member States to assess on the basis of a clear set of criteria the proportionality and justification when introducing new (or amending existing) profession requirements.

35. In sum, European (and notably EU) countries have already been active in the area of occupational entry reforms over the past two decades (see also Table 3), but the need for reassessing existing legislation persists given the remaining regulatory variability. Considering that the relative weight of the services sector in the economy continues to rise, the need for reassessment might even grow in importance, as discussed by Mocetti et al (2019). In their study, the authors show that in Italy the share of regulated occupations increased from 20 percent to 24 percent between the mid-90s and 2019 due solely to changes in industrial structure, with more people working in regulated professions - a phenomenon that is likely to be shared by most advanced economies. 
Table 3. Selected occupational entry reforms: Europe

\begin{tabular}{|c|c|c|}
\hline Country & Year & Reform \\
\hline Germany* & 2004 & Amendment of the Crafts code reduced the number of licensed occupations from 94 to $41^{*}$ \\
\hline Italy & 2006 & $\begin{array}{l}\text { The 'Bersani' decree abolished minimum prices and reduced restrictions to advertising and to } \\
\text { inter-professional co-operation }\end{array}$ \\
\hline $\begin{array}{l}\text { United } \\
\text { Kingdom }\end{array}$ & 2007 & Legal Service Board reform - separation of regulatory and representative powers \\
\hline Spain & 2009 & $\begin{array}{l}\text { Reduction of barriers for individuals from other regulated occupations to exercise reserved } \\
\text { activities, reduction of tariffs and restrictions on advertising }\end{array}$ \\
\hline Poland & $\begin{array}{l}2009 ; \\
2013\end{array}$ & Modification of the rules of entry to the profession of advocate and legal advisors \\
\hline Greece & 2011 & Abolishment of unjustified redundant regulations related to regulated professions \\
\hline Italy & 2012 & $\begin{array}{l}\text { Relaxation of multiple restrictions including both access and conduct regulations (loosened } \\
\text { terms for traineeships, the abolition of tariffs, advertising and legal form restrictions) }\end{array}$ \\
\hline Portugal & 2013 & Relaxation of entry requirements for occupations that were not regulated by professional bodies \\
\hline Slovenia & 2013 & Reduction of the number of craftsmen occupations required to obtain a license \\
\hline Belgium & 2019 & Deregulation of craftsmen occupations in the Flemish region \\
\hline
\end{tabular}

Note: The 2004 reform of Germany was subsequently reversed in 2019 for 19 selected crafts (Deutscher Bundestag, 2019). Source: Canton, Ciriaci and Solera (2014), Koumenta et al. (2019) and OECD Reform Tracker

\subsubsection{North America - United States}

36. The rationale and the economic benefits of occupational licensing are increasingly being questioned in US academic and policy circles, with the issue now becoming a bipartisan topic (Pagliero, 2019). The average share of workers that are licensed stood at 25 percent in 2013, with figures varying from 12 percent in South Carolina to 33 percent of workers in lowa (Figure 11) and the overall share of workers covered by regulations had increased from 1 in 20 workers in 1950 to 1 out of 5 workers in 2010 (Kleiner and Kruger, 2010). Differences between occupational entry regulations across states are as wide as differences across the countries covered by the OER indicator (Figure 12), pointing to a need to review and harmonise licensing systems.

Figure 11. The share of the workforce holding an occupational license in the United States (2013)

Percentage of licensed workers (\%)

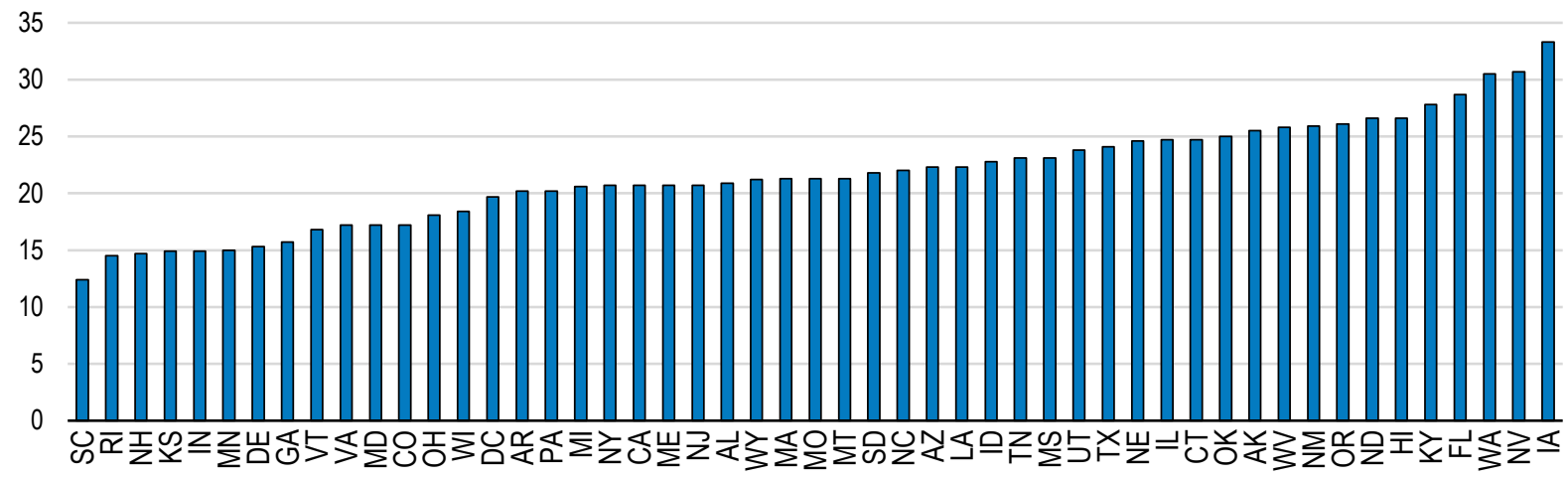

Note: Compilation based on an analysis of data from a Harris poll of 9,850 individuals conducted in the first half of 2013 and Kleiner and Vorotnikov (2017). The abbreviation of US states can be found in Annex E.

Source: Kleiner (2017) based on analysis of data from a Harris poll and Kleiner and Vorotnikov (2017). To download this graph, please visit https://bit.ly/2w4MR2X 
37. Regulatory patterns in the US differ in various ways from those prevailing in European countries. For instance, while EU regulations tend to be similar for craftsmen, given that they are often bundled in trade and crafts codes, US regulations are more diverse in this regard: butchers and bakers are fully deregulated, but hairdressers and aestheticians are typically subject to relatively higher entry barriers, even compared with European levels for the same professions (Figure 3). It is likely that this approach reflects a tradition of focusing regulations on credence goods, i.e. to services that are difficult to ascertain by the consumer even after the purchase, as would be the case for a haircut or beauty treatment. US States also more frequently apply mobility restrictions on personal services than European countries (Figure 13, Panel A). It is not obvious why mobility restrictions should be more common within the highly integrated US economy than in European countries, which often have different institutional settings and language barriers.

38. Another peculiar trait of the US licensing system, not captured by the OER, relates to the treatment of individuals with criminal records. Licensing laws often contain rules prohibiting anyone with a criminal record from obtaining an occupational license, irrespective of whether the committed offence is relevant to the practice of the occupation or poses a substantive risk to public safety. Moreover, many states' laws contain "good-character" provisions that grant licensing boards broad discretion to deny applications due to an applicant's criminal history, including for minor offences and even arrests that never led to a conviction (Carpenter et al., 2017). With one out of three Americans having a criminal record (Carson, 2016), this feature of the US licensing system creates significant hurdles to professional entry and the reintegration of criminal offenders, who might not be able to return to their original occupation after the prison term. ${ }^{16}$

39. While Table 4 is not comprehensive, efforts to reform US occupational regulations over the past two decades were spare, both at the federal and the state level. Reforms that passed also rarely involved a delicensing of occupations (see e.g. in Michigan and Arizona), but more often just changed the licensing system or established the need for reviewing existing regulations (e.g. Utah, Wisconsin, Florida, Nebraska; Kilmer, 2019). An headline-making exemption to this rule was achieved by the Federal Trade Commission (FTC), who has been active in applying antitrust legislation to occupational licensing boards. In North Carolina Board of Dental Examiners v. FTC 2010, the FTC objected the board's practice of issuing ceaseand-desist order to non-dentists offering teeth whitening services without a dentistry license for being uncompetitive - a decision that was backed by the Supreme Court in 2015. The FTC stipulated that licensing boards which are mainly composed of active professionals should be immune from antitrust law only if they are "actively supervised" by the state (Supreme Court of the United States, 2014). Setting a precedent with this case, states are now compelled to rework the rules of who can serve the boards, or create regulatory oversight bodies for the 1800 currently active bodies in the US (see also Box 1).

\footnotetext{
${ }^{16}$ This is especially true for minorities, who only represent 12.6 percent of the general population, but make up for 27 percent of all arrests (NCSL, 2018).
} 
Figure 12. Within-country variance of regulatory stringency across occupations: US

Panel A: Personal services

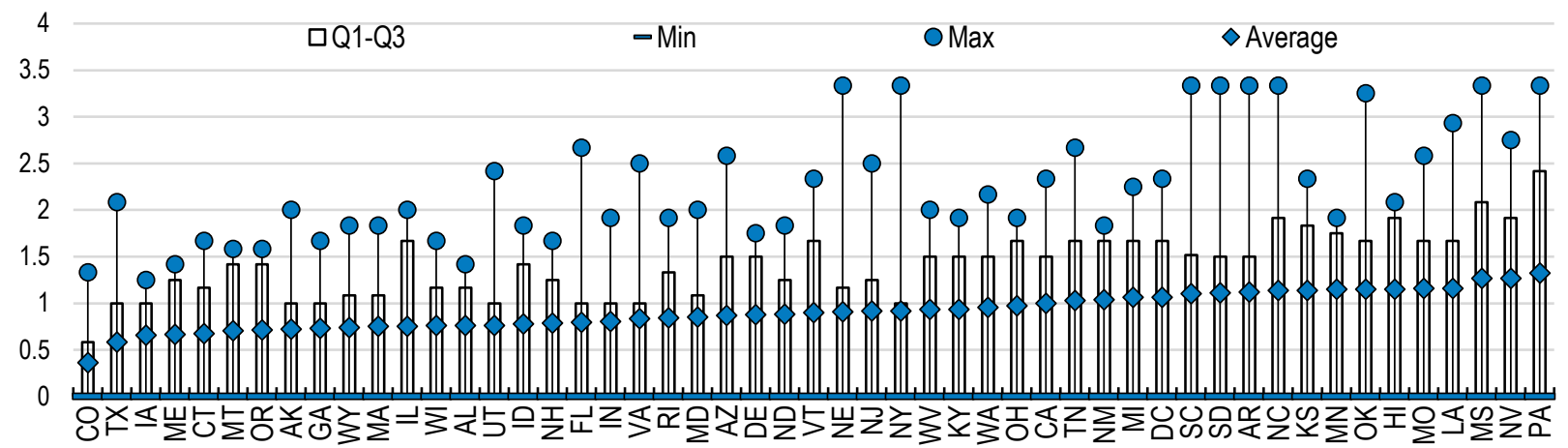

Panel B: Professional services

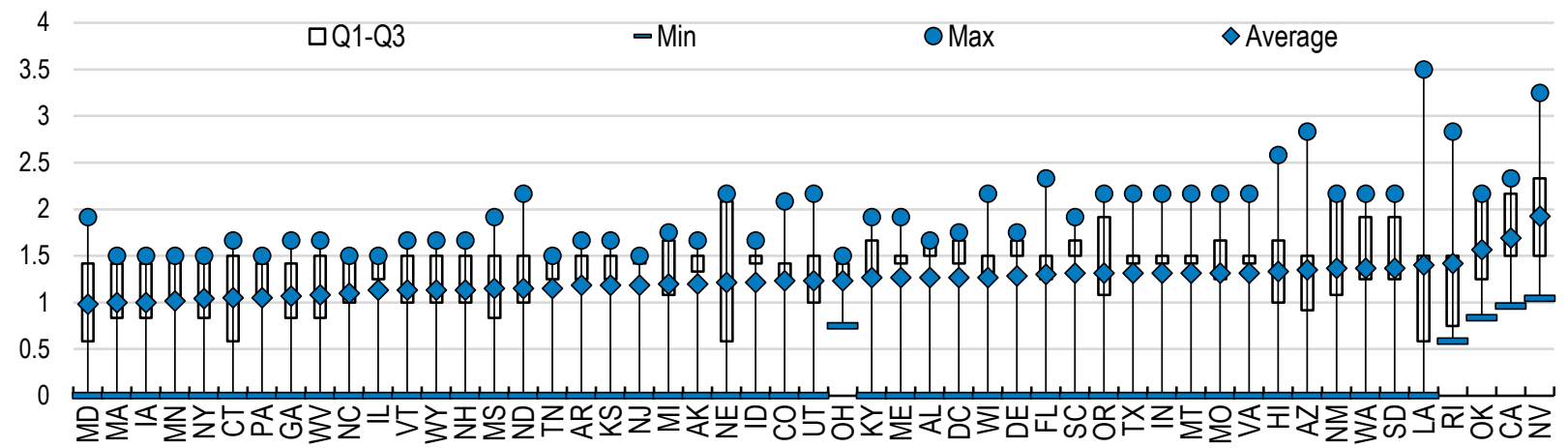

Note: An indicator value of 0 indicates the absence of regulations, 6 reflects a fully regulated market. The abbreviation of US states can be found in Annex E.

Source: OECD OER database. To download this graph, please visit https://bit.ly/2w4MR2X

Figure 13. Composition of average regulation by sub-indicator: US states

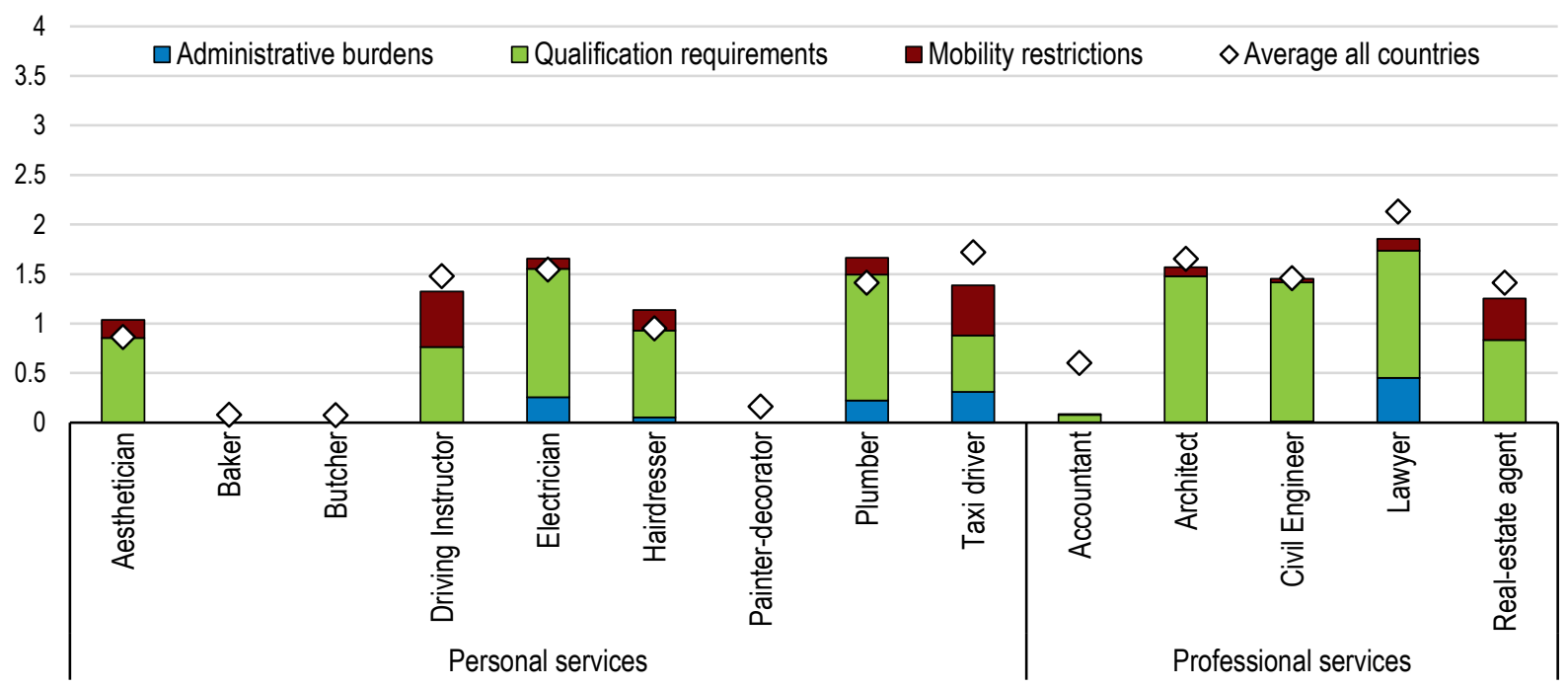

Note: An indicator value of 0 indicates the absence of regulations, 6 reflects a fully regulated market. The graph displays unweighted average OER levels of all US states.

Source: OECD OER database. To download this graph, please visit https://bit.ly/2w4MR2X 
Table 4. Selected occupational entry reforms: United States

\begin{tabular}{|c|c|c|}
\hline State & Year & Reform \\
\hline Florida & 2011 & Reduction/exemption of licensing fees for military veterans and low-income \\
\hline Michigan & $\begin{array}{l}2013- \\
2014\end{array}$ & Out of 87 occupations reviewed, 6 became unlicensed \\
\hline \multirow[t]{2}{*}{ Arizona } & 2016 & Out of 102 occupations reviewed, 5 became unlicensed \\
\hline & 2019 & First US State to recognize all out-of-state licensures (HB 2569) \\
\hline Nebraska & 2016 & Exception of license for natural hair braiders \\
\hline Utah & 2017 & Reduction of entry regulations for electricians, plumbers and contractors \\
\hline Wisconsin & 2017 & $\begin{array}{l}\text { Reduction of entry regulations for barbers, cosmetologists, aestheticians, electrologists, and } \\
\text { manicurists }\end{array}$ \\
\hline
\end{tabular}

Source: Kleiner (2019), Kilmer (2019).

\subsubsection{North America - Canada (co-authored by Tingting Zhang)}

40. The Canadian approach to regulating occupational entry is broadly similar to that of Europe and the United States, with the exception of a few differences related to personal services. In particular, as was displayed by Figure 14 and Figure 15, personal services workers in Canada, when they are regulated, are often subject to higher average levels of regulations than in Europe, and sometimes also in the US. In many cases, these differences result from the obligation to join a professional association and to accumulate work experience before obtaining the permission to work.

41. Interestingly, regulatory approaches for personal services occupations still tend to vary significantly across provinces (Figure 14) despite various policy initiatives aiming at the reduction of these disparities. For instance, the Red Seal Program Support to the mutual recognition of personal services or skilled trades - among provinces sets common skill standards among tradespeople across Canada. Through a special exam, it endorses candidates with a certification granting the right to work in any province, provided the worker is registered with the provincial trade board. More recently, the Atlantic Apprenticeship Harmonization Project (AAHP) (2016) also proposed to harmonize the requirements and standards for 10 skilled trades, including electricians and plumbers, in New Brunswick, Nova Scotia, Newfoundland, and Prince Edward Island.

42. Further policy initiatives that have led to the reduction of inter-provincial gaps in OER over time notably include a series of trade agreements (see Table 5). Since 1995, for instance, Chapter 7 of the Agreement on Internal Trade (AIT) counters the negative impact of occupational licensing on interprovincial labour mobility by enhancing the cooperation between the federal government and all provinces and territories. The Agreement particularly focuses on two crucial mechanisms of occupational licensing. First, it provides legislative guidance to professional associations for removing residency requirements in their licensing standards. Second, it encourages regulatory bodies to establish mutual-recognition clauses to ease licensing barriers across provinces. More recently, this commitment was reaffirmed by the Canadian Free Trade Agreement (CFTA, 2017), although provinces maintain the right to additional certification requirements, e.g. based on public security, safety concerns, or consumer protection grounds. At the provincial level, Alberta, British Columbia, and Saskatchewan further formulated the New West Partnership Trade Agreement in 2010, whereby "any worker certified for an occupation by a regulatory authority of a Party shall be recognized as qualified to practice that occupation by the other Party."

43. Professional service regulation in Canada stands out in this sample due to its low regulatory variation across provinces (see Figure 14), partly because the licensing bodies of all professional occupations included in the OER, as well as those of nurses, had inter-provincial mutual-recognition clauses at the end of 2019. With the exception of Quebec, where labour mobility continues to be restricted, largely because of language requirements, almost all professional associations' websites now also contribute to the transparency of foreign mobility requirements, by providing licensing requirement 


\section{8}

ECO/WKP(2020)14

information, describing the qualification assessment process and listing the additional training requirements. Importantly, Canada is also the only country in the OER sample that allows unlicensed accountants, architects and civil engineers to work under the supervision of a licensed supervisor in at least one province (Figure 5).

44. As regards the professional integration of foreign trained immigrants, a 2010 Ontario survey reported that immigrants were significantly less likely to work in the professions in which they were trained outside Canada (44\% versus $76 \%$ for nationals; R.A. Malatest \& Associates Ltd., 2010). To remedy these concerns, federal and provincial/territorial governments launched the Pan-Canadian Framework for the Assessment and Recognition of Foreign Qualifications (2009) and, more recently, renewed the Action Plan for Better Foreign Qualification Recognition (2014), both of which are intended to facilitate more effective foreign qualification recognition. In addition, several provinces also established bridge programs to support foreign-trained and practised professionals to acquire the necessary skills and experience (e.g. Ontario Bridging Participant Assistance Program or the Manitoba Bridging and Gap Training Programs). All those practices have significantly lowered the entry barriers for foreign-trained practitioners.

Figure 14. Within-country variance of regulatory stringency across occupations: Canadian provinces

Panel A: Personal services

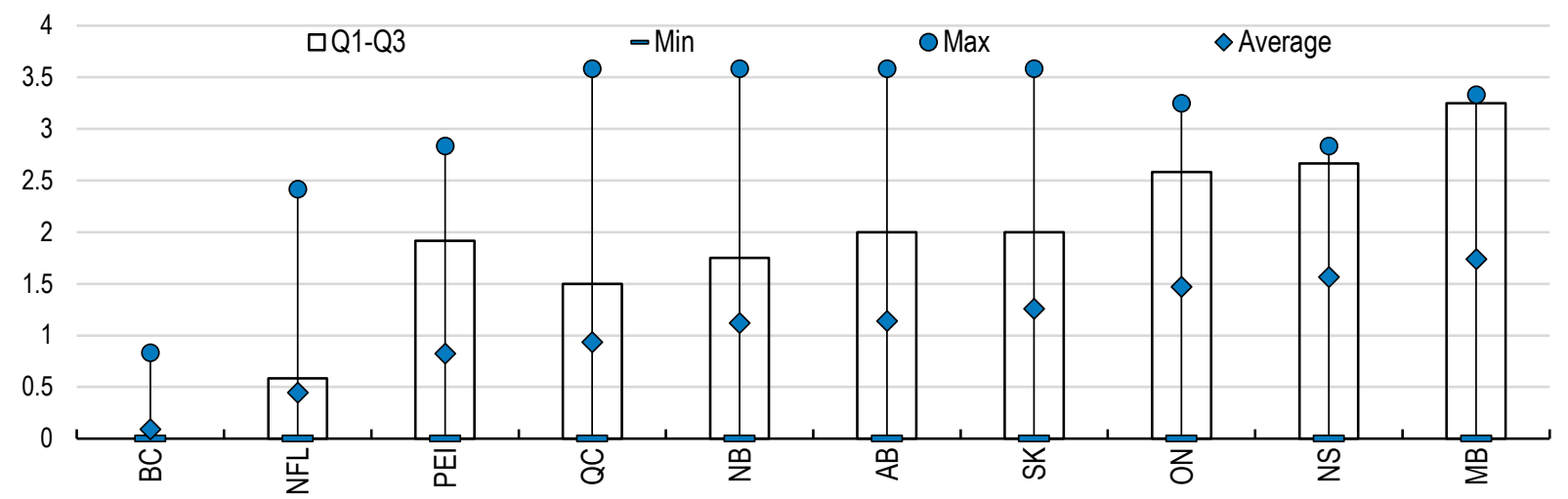

Panel B: Professional services

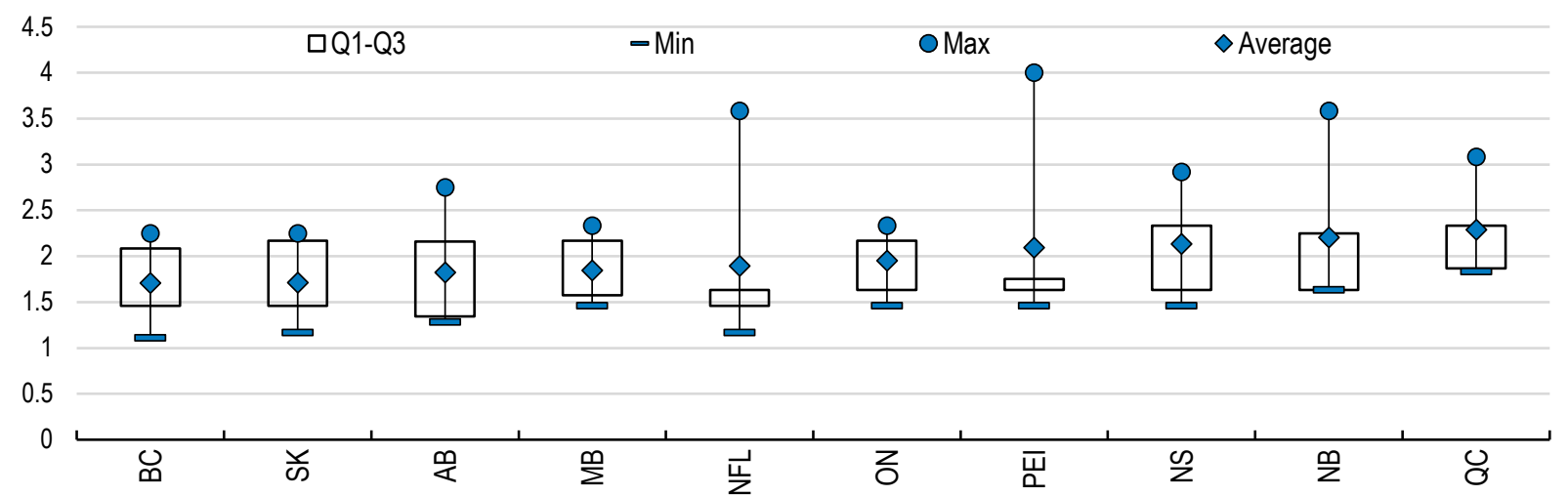

Note: An indicator value of 0 indicates the absence of regulations, 6 reflects a fully regulated market. The abbreviation of Canadian provinces can be found in Annex E.

Source: OECD OER database. To download this graph, please visit https://bit.ly/2w4MR2X 
Figure 15. Composition of average regulation by sub-indicator: Canada

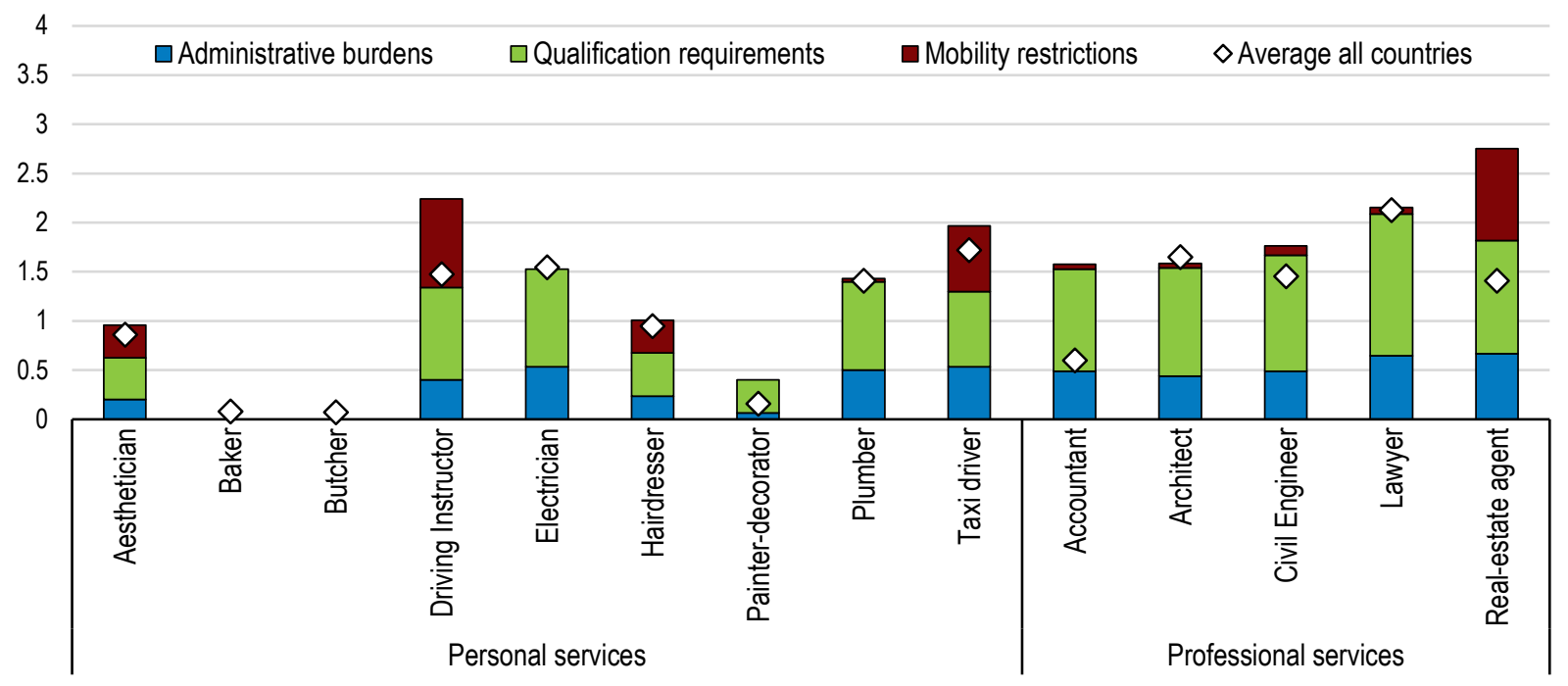

Note: An indicator value of 0 indicates the absence of regulations, 6 reflects a fully regulated market. The graph displays unweighted average OER levels of all Canadian provinces.

Source: OECD OER database. To download this graph, please visit https://bit.ly/2w4MR2X

\section{Table 5. Selected occupational entry reforms: Canada}

\begin{tabular}{|c|c|c|}
\hline Province & Year & Reform \\
\hline All & 2009 & $\begin{array}{l}\text { Amendment of the } 1995 \text { Agreement on Internal Trade (AIT) to remove labour mobility } \\
\text { barriers for certified workers so they will be able to move freely to work where opportunities } \\
\text { exist. }\end{array}$ \\
\hline All & 2009 & $\begin{array}{l}\text { Assessment and Recognition of Foreign Qualification- A Pan Canadian Framework for the } \\
\text { Assessment and Recognition of Foreign Qualifications, was established which represents a } \\
\text { joint commitment by federal, provincial and territorial governments to work together to } \\
\text { improve the foreign qualification assessment and recognition systems in Canad }\end{array}$ \\
\hline $\begin{array}{l}\text { Alberta, British } \\
\text { Columbia, and } \\
\text { Saskatchewan }\end{array}$ & 2010 & $\begin{array}{l}\text { New West Partnership Trade Agreement (2010), whereby "any worker certified for an } \\
\text { occupation by a regulatory authority of a Party shall be recognized as qualified to practice } \\
\text { that occupation by the other Party." }\end{array}$ \\
\hline All & 2014 & Action Plan for Better Foreign Qualification Recognition (2014) \\
\hline All & 2015 & Apprentice Mobility Protocol \\
\hline All & 2016 & $\begin{array}{l}\text { Atlantic Apprenticeship Harmonization Project (AAHP) (2016) harmonize the requirements } \\
\text { and standards for } 10 \text { skilled trades, including electricians and plumbers, in New Brunswick, } \\
\text { Nova Scotia, Newfoundland, and Prince Edward Island }\end{array}$ \\
\hline All & 2017 & $\begin{array}{l}\text { Canadian Free Trade Agreement - reaffirming labour mobility provisions established under } \\
\text { the } 2009 \text { version of the Agreement on International Trade. }\end{array}$ \\
\hline
\end{tabular}

Source: Zhang (2017).

\subsubsection{Israel (co-authored by Yair Osheroff)}

45. Israel imposes relatively few occupational entry barriers on the personal and professional services assessed by this study (Figure 16), especially in comparison with EU countries. In the personal services segment, for instance, only electricians, taxi drivers and driving instructors are regulated. A similar picture emerges for professional services, where regulatory levels are similar or lower than in Europe, with the exception of real estate agents. Comparing the composition of regulations however shows that less emphasis is placed on qualification requirements, while many professions suffer from a lack of recognition mechanisms that would allow individuals with qualifications earned abroad to practice in Israel. 
Figure 16. Composition of average regulation by sub-indicator: Israel

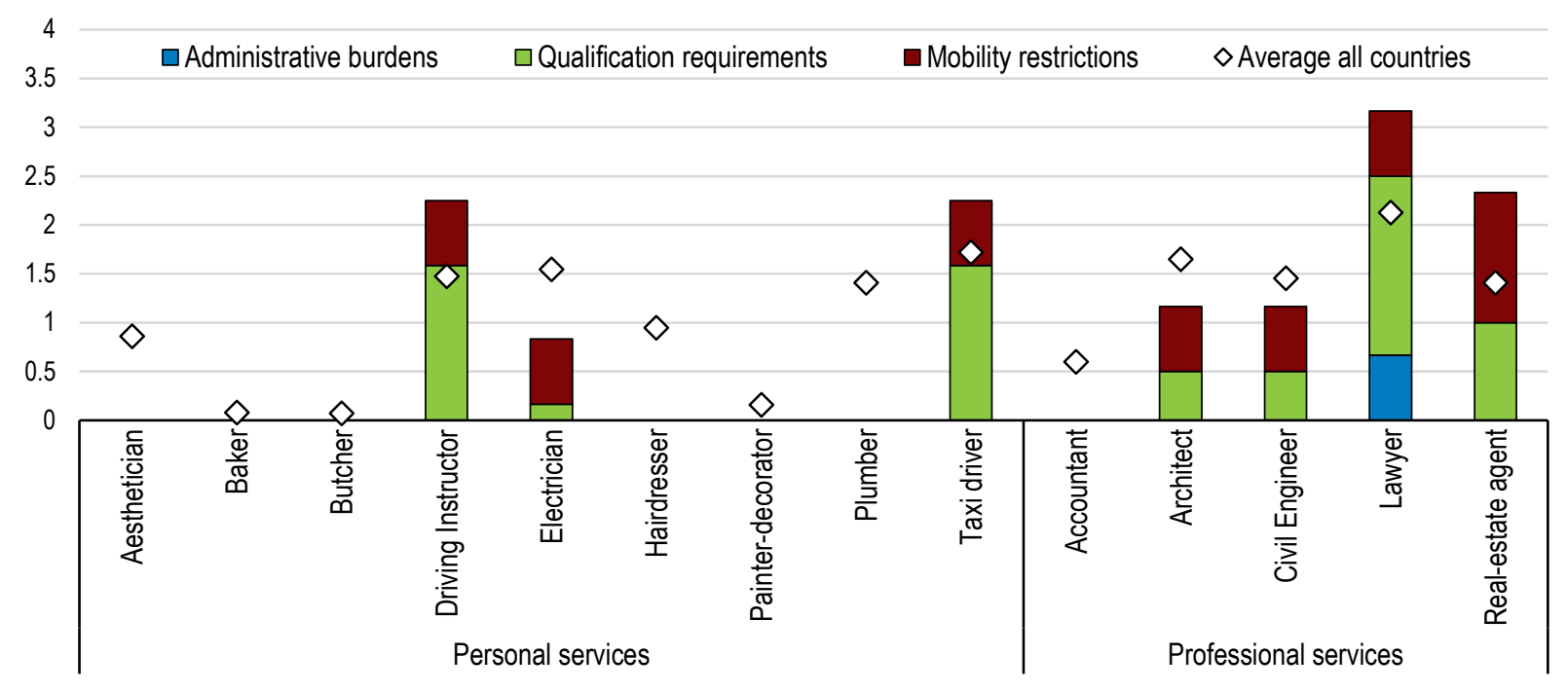

Note: An indicator value of 0 indicates the absence of regulations, 6 reflects a fully regulated market.

Source: OECD OER database. To download this graph, please visit https://bit.ly/2w4MR2X

46. Preliminary evidence suggests that, as in the US, the practice of regulating occupational entry in Israel has historically been on the rise (Figure 17; Osheroff and Kleiner, 2019). This trend was accompanied by two phenomena:

- Fractionalisation: Some professions, initially falling under one regulation, were split over time into several occupations with more specific duties and responsibilities, linked with an increasing degree of occupational entry regulations. For instance, the profession of electricians was split in 1985 into seven categories, ranging from electrician-assistant to electrician-engineer (Regulation of Electricity-1985). ${ }^{17}$ Each rank is entitled to perform the tasks associated with its rank and all ranks below.

- Ratcheting up: Numerous professions have to comply with increasing qualification requirements. One prominent feature of ratcheting up is the academisation of occupations, which occurs when an academic qualification is added to the existing set of requirements to obtain an occupational license. For example, midwives only required a six-month course to be licensed in 1929, while over the years the licensing requirements evolved to further include a bachelor in nursing, a nine-month course in midwifery, an internship, and exam. ${ }^{18}$ Another prominent feature of the ratchet-up process takes the form of longer internships. Qualification requirements for accountants, for instance, initially included no internship (Companies Ordinance of 1921), but the Accountants Act of 1955 introduced a mandatory two-year internship, still prevailing today. Similar developments were observed over time for architects and engineers, which saw the duration of mandatory internships increase from 1 year to 3 years.

\footnotetext{
17 The exact list of ranks, from the least to most restricted, is as follows: assistant-electrician, practical-electrician, certified-electrician, major-electrician, technician-electrician, practical-engineer-electrician, and engineer-electrician.

18 Midwifes Ordinance-1929; Regulation of the People's Health (Practitioners of Nursery in Hospitals)-1988
} 


\section{Figure 17. Occupational licensing in Israel historically follows an upward trend}

Number of licensed occupations in Israel, 1918-2018

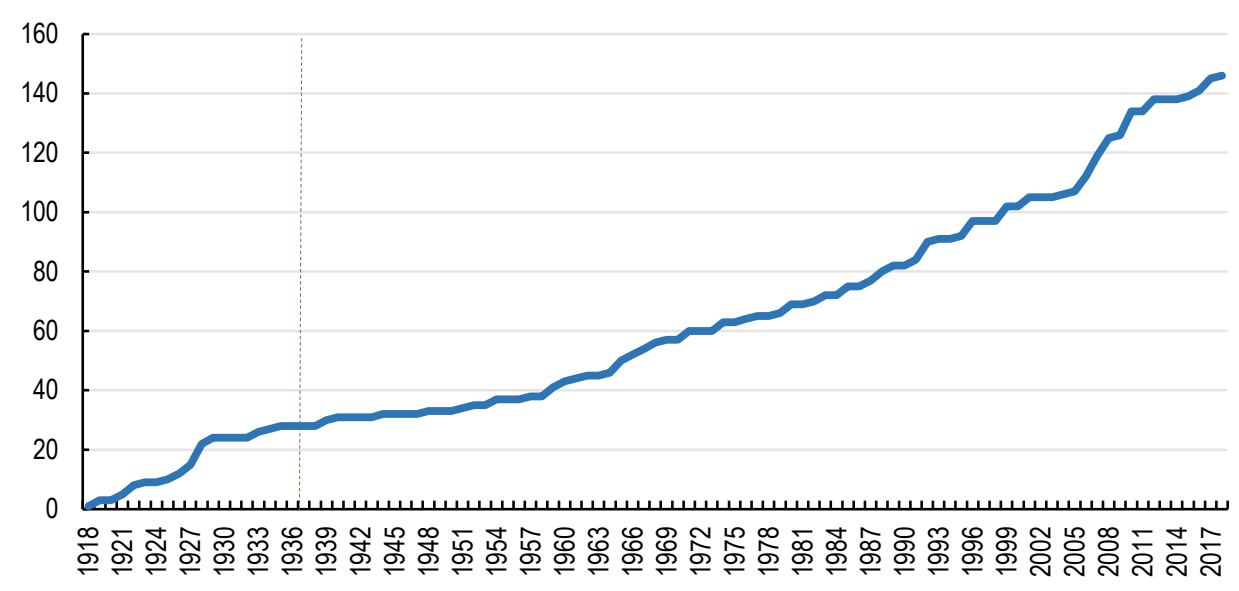

Note: The dashed line represents the establishment of Israel in May, 1948.

Source: Graph constructed by Y. Osheroff based on Osheroff and Kleiner (2019).

\subsection{Detailed results - Non-OECD countries}

\subsubsection{India}

47. The OER is currently the only cross-country indicator recording entry requirements into personal and professional services in India, as this country is not included in the most recent vintage of the OECD PMR. The focus is on occupational entry regulations imposed by the representative State of Delhi, as regulations were found to be almost identical in the neighbouring Uttar Pradesh and Haryana states. Mobility restrictions are recorded with respect to other countries, since occupational mobility between Indian states is usually unrestricted.

48. Indian states apply few entry regulations on personal services, with taxi drivers and driving instructors bearing the highest regulatory burden (Figure 19). Recently, however, the Indian Supreme Court eased regulations for taxis, by allowing any holder of a Light Motor Vehicle license to drive a taxi, without the need for a commercial license. Interestingly, the significant entry barriers for driving instructors stand in contrast to the low wage level of this profession, resulting from the absence of mandatory theory and driving classes before students can take the state driving exam.

49. Occupational entry regulations in professional services are typically more lenient than in Europe, but several reforms recently increased entry barriers. For reasons of transparency, real estate agents now have to register with the Real Estate Regulatory Authority (RERA) whenever a real estate project exceeds 500sqm or eight apartments (Real Estate Act, 2016), and this license has to be renewed every five years. Similarly, the Bar Council of India $(\mathrm{BCl})$ requires lawyers to renew their license every 5 years since June 2012. At the same time, while the BCl only allows citizens of India to provide legal services, a 2018 ruling by the Supreme Court (see "Bar Council of India v. A K Balaji \& Ors") now allows foreign lawyers to provide consultancy services on a fly-in-fly-out basis.

50. Like other emerging economies, the Indian government faces the difficult task of promoting employment and transparency, while reducing informality. Still today, around $90 \%$ of the total workforce are employed in the informal sector and are therefore not covered by any social protection scheme (CII, 2014). Several governmental schemes (notably the Skill India mission) and start-ups thus promoted initiatives that allow workers to access training programmes, ultimately endowing applicants with an official certificate of their skills. In so doing, the government hopes to help support workers in better signalling their 
skills on the job market, and encourage employers to offer applicants a formal, rather than informal, contract.

\section{Figure 18. Composition of average regulation by sub-indicator: India}

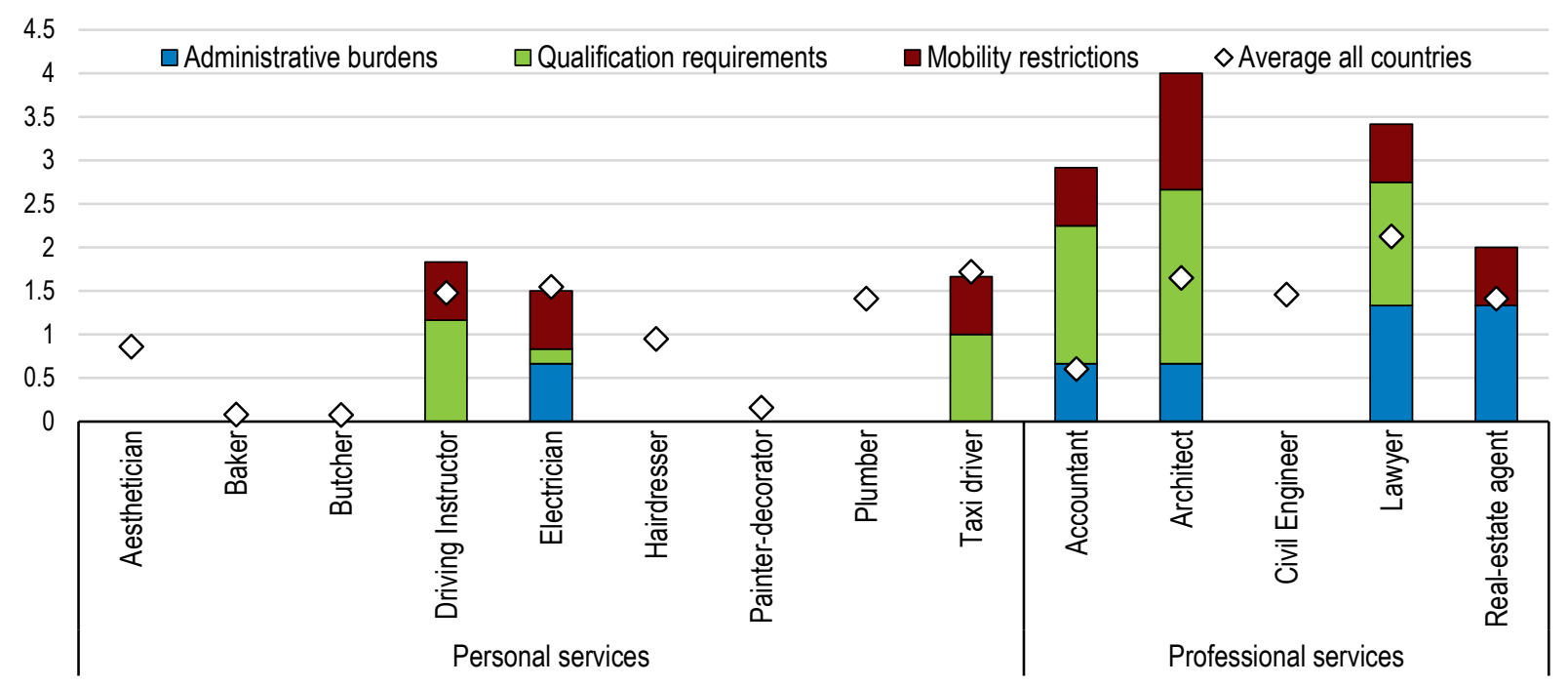

Note: An indicator value of 0 indicates the absence of regulations, 6 reflects a fully regulated market.

Source: OECD OER database. To download this graph, please visit https://bit.ly/2w4MR2X

\subsubsection{South Africa}

51. As evidenced by the PMR 2018, regulatory barriers in South Africa are higher than in most OECD countries on many accounts, including for professional services. Accordingly, the OER displays indicator values up to twice as high as the in-sample average (Table 2, Figure 19). ${ }^{19}$ Besides stringent qualification requirements, these high values often reflect presence of mobility restrictions on foreign qualified professionals. Access is mostly hampered by the absence of a transparent recognition mechanisms, with the exception of lawyers, whose qualification is automatically recognized if it was obtained in Swaziland, Namibia, Lesotho and the former South African Bantustans (so-called "TBVC states").

52. By contrast, there are almost no occupational entry requirements for personal services. Instead, voluntary certification (or trade tests) helps to signal quality and determines the annual remuneration package set by the Bargaining Council for the Hairdressing, Cosmetology, Beauty and Skincare Industry. There are, however, strong perceptions that courses are too long, with inaccessible language and terminology, and opportunities for workplace-based learning at approved salons are scarce, resulting in many students not completing their formal qualifications and not being well-prepared for trade tests (DHET, 2017). Moreover, the qualifications and curriculum currently offered to hairdressers to be granted the certificate are biased towards Caucasian hair skills, and are not relevant to those required by the informal sector.

53. Entry to the occupations of bakers, butchers and plumbers is entirely unregulated. Any individual may sell meat, provided they comply with various legislated acts regarding cleanliness and origin. Similarly, anyone is free to open a bakery and sell bread provided they comply with the existing health regulations. For plumbers, only the parts and materials used must subscribe to the standards set by the South African Bureau of Standards (SABS). Interestingly, insurances play a large role in ensuring quality in the plumbing industry. In order to meet the high standard required by insurance companies, however, plumbers need to

${ }^{19}$ While not yet included in the OER database, the government also recently signed a bill setting out various new requirements for real-estate agents in order to get licensed (South Africa Government Gazette, 2019). 
have a countrywide qualification and be registered with the Plumbers Industry Regulatory Board. While not being mandatory, these steps help plumbers signal their competence, and help municipalities to identify skilled professionals qualified in handling the scarce water resources in South Africa.

54. As for India, South African regulators need to take into account a significant share of informal employment (18 percent of all employed; STATS SA, 2019) and corruption. A case in point is the driving instructor industry, where weak monitoring procedures and pervasive bribery have been identified as serious barriers for individuals to obtain a driver's licence (Corruptionwatch, 2017). By identifying professionals "of good character", occupational entry regulations thus also serve as a tool to reduce corruption concerns, although more would have to be done to fully eliminate the issue. However, while South Africa's level of informality is high in comparison to OECD countries, it is below the norm of emerging economies (ILO, 2020). In light of the economy's high unemployment rate and elevated levels of occupational entry regulations, this observation is surprising and suggests the presence of further structural factors inhibiting employment.

\section{Figure 19. Composition of average regulation by sub-indicator: South Africa}

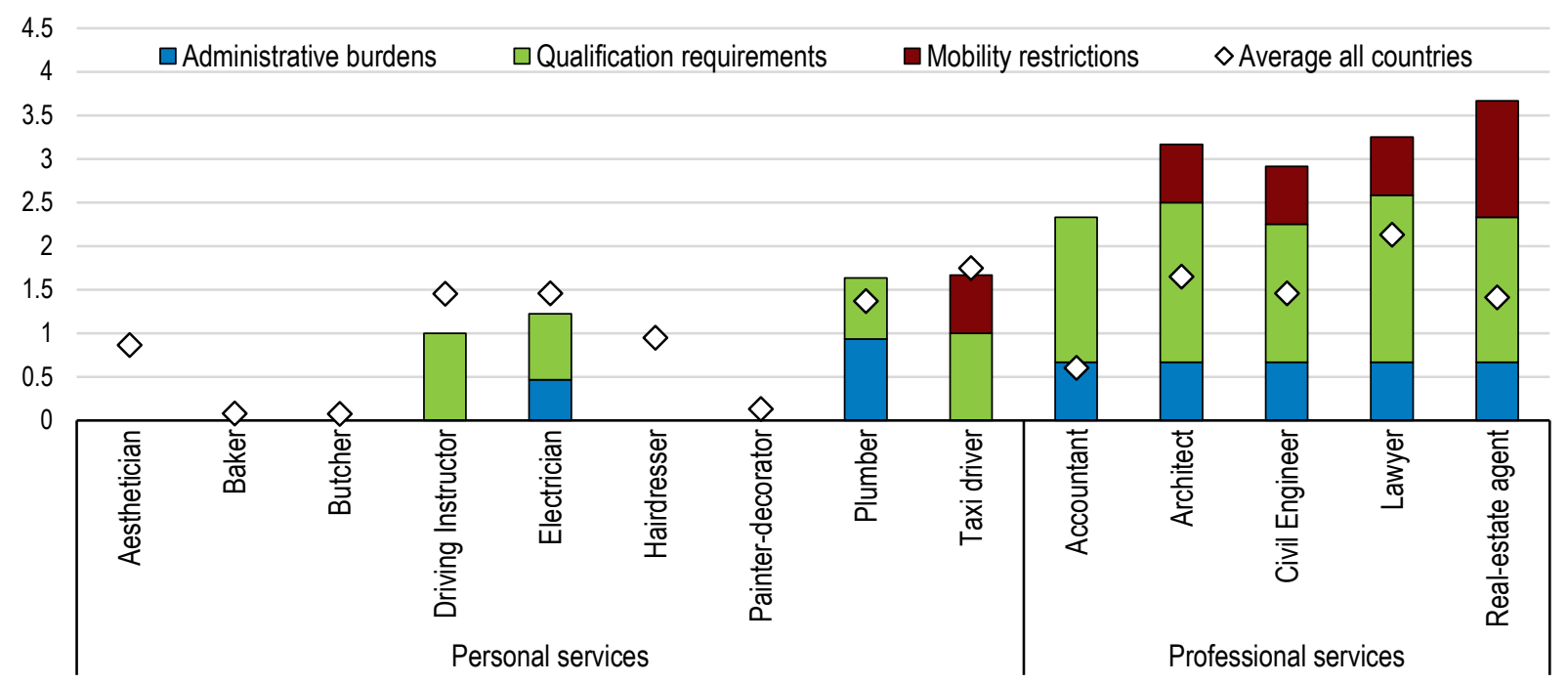

Note: An indicator value of 0 indicates the absence of regulations, 6 reflects a fully regulated market.

Source: OECD OER database. To download this graph, please visit https://bit.ly/2w4MR2X

\section{Policy recommendations and conclusions}

55. With ambiguous effects on quality of service and proven harmful effects on the economy - via lower employment, higher prices and lower productivity - the time to review and reassess the necessity of OER is now. Such a review is all the more needed in view of recent evidence showing that the share of workers covered by such regulations is high and has been increasing over time. The OER indicator presented in this paper shows that there is ample scope for streamlining regulations, as approaches to meet the stated public objectives of OER vary a lot both across and within countries.

56. At the same time, reviewing occupational entry regulations does not imply that they always be removed, as the economic reasons for their existence can be sound (e.g. in the presence of strong asymmetries of information between providers and customers or prevent the risk of moral hazard in some cases). However, international evidence would suggest that reviewing such regulations could usefully involve a series of actions, including by (1) making means more proportionate to ends (e.g. inspired by successful experiences abroad); (2) shifting the focus from the quality of inputs when the purpose of the regulation is to ensure that the outcome (e.g. a building standard or the quality of meat sold) rather than 


\section{4 | ECO/WKP(2020)14}

the service itself is of desired quality (e.g. via ex-post evaluation); (3) extending mutual recognition of entry requirements across jurisdictions (especially within federal countries and economic unions) and (4) eliminating mobility restrictions that create unnecessary labour market rigidities. Where appropriate, licensing systems could also be replaced with less distortionary certification schemes or be targeted at supervisors only. In this case, consumer information platforms (e.g. service quality comparison platforms) could then help to alleviate potential information asymmetry concerns. Indeed, a number of countries already focus on OER and implemented a number of reforms in this area. Yet, given the rising importance of these labour market institutions, it is time for governments to take more decisive action. 


\section{References}

Aldridge, S. (2008), "The regulation of health professionals: an overview of the British Columbia experience", Journal of medical imaging and radiation sciences, Vol. 39(1), pp. 4-10, https://doi.org/10.1016/j.jmir.2008.01.001.

Allied Tube v. Indian Head, Inc., 486 U.S. 492 (1988), United States Supreme Court.

Anderson D. M., R. Brown, K. K. Charles and D. I. Rees (2016), "The Effect of Occupational Licensing on Consumer Welfare: Early Midwifery Laws and Maternal Mortality", National Bureau of Economic Research (NBER) Working Papers, No. 22456, https://doi.org/10.3386/w22456.

Bambalaite, I., G. Nicoletti and C. von Rueden (2020), "Occupational entry regulations and their effects on productivity in services: firm-level evidence", OECD Economics Department Working Papers No. 1605, OECD Publishing.

Bar Council of India v. A K Balaji \& Ors (2018). Supreme Court of India, http://mappingadr.in/bar-councilof-india-v-a-k-balaii-ors/.

Blair, P. Q., and B. W. Chung (2018a), "How much barrier to entry is occupational licensing?", NBER Working Paper Series, No. 25262, https://doi.org/10.3386/w25262.

Blair, P. Q., and B. W. Chung (2018b), “Job Market Signalling through Occupational Licensing”, NBER Working Paper Series, No. 24791, https://doi.org/10.3386/w24791.

Cai, J. and Kleiner, M. M., (2016), "The labor market consequences of regulating similar occupations: The licensing of occupational and physical therapists", Upjohn Institute Working Papers, 16-259.

Canton, E., D. Ciriaci, and I. Solera (2014), "The Economic Impact of Professional Services Liberalization", European Commission, DGEcoFin, European Economy Series, Economic Papers No. 533, September, https://doi.org/10.2765/71387.

Carpenter, D. M., and L. Knepper, (2017), "License to work. A National Study of Burdens from Occupational Licensing", https://ii.org/wpcontent/themes/ijorg/images/ltw2/License to Work 2nd Edition.pdf

Carpenter, D. M., L. Knepper, K. Sweetland and J. McDonald, (2018), "The Continuing Burden of Occupational Licensing in the United States", Economic Affairs, Vol. 38(3), pp. 380-405, https://doi.org/10.1111/ecaf.12319.

Carroll, S. and R. Gaston (1981), "Occupational Restrictions and the Quality of Service Received: Some Evidence”, Southern Economic Journal, Vol. 47(4), pp.959-976, https://doi.org/10.2307/1058155.

Carson, E. A. (2016), Number of Prisoners in 2016, Bureau of Justice Statistics, https://www.bjs.gov/index.cfm?ty=pbdetail\&iid $=6187$

Census Bureau (2019), National Population Totals and Components of Change: 2010-2019.

Confederation of Indian Industry (CCI), (2014), "An Analysis of the Informal Labour Market in India", http://www.ies.gov.in/pdfs/CII\%20EM-october-2014.pdf

Corruptionwatch (2017), License corruption draws youth off the straight path, https://www.corruptionwatch.org.za/licence-corruption-draws-youth-off-straight-narrow/.

Deutscher Bundestag (2019), Meis-terpflicht für zwölf Hand-werke wieder ein-geführt, https://www.bundestag.de/dokumente/textarchiv/2019/kw50-de-handwerksordnung-670540. 
DHET (2017), “Understanding Skills Supply and Demand in the Hairdressing Industry”, Department: Higher Education and Training, Republic of South Africa.

European Commission (2015), "Business services - Assessment of Barriers and their Economic Impact".

Gittleman, M., M. A. Klee, and M. M. Kleiner (2015), "Analyzing the Labor Market Outcomes of Occupational Licensing”, NBER Working Paper, No. 20961, https://doi.org/10.3386/w20961.

Grajzl, P and P. Murrell (2007), "Allocative Law-Making Powers: Self-Regulation Versus Government Regulation", Journal of Comparative Economic, No. 35, pp. 520-545.

International Labour Organisation (2020), Statistics on the Informal Economy, available at https://libguides.ilo.org/informal-economy-en/statistics

International Standard Classification of Occupations: ISCO-08 (2012), "Definitions of Major Groups", International Labour Office.

Johnson, J. and M. M. Kleiner (2017), "Is Occupational Licensing a Barrier to Interstate Migration?", Federal Reserve Bank of Minneapolis, Staff report No. 561, https://doi.org/10.21034/sr.561.

Kilmer, M. (2019), "A look at Occupational Licensing Reform across the United States", Arkansas Center for Research in Economics, University of Central Arkansas.

Klee, M.A. (2013), "How Do Professional Licensing Regulations Affect Practitioners? New Evidence", US Bureau of Labor Statistics, SEHSD Working Paper, No. 30, pp.723-756.

Kleiner, M. M. and R. T. Kudrle (2000), "Does Regulation Affect Economic Outcomes? The Case of Dentistry", The Journal of Law and Economics, Vol. 43, No. 2, pp.547-582, https://doi.org/10.1086/467465.

Kleiner, M. M. (2006), "Licensing occupations: Ensuring quality or restricting competition?", WE Upjohn Institute for Employment Research, https://doi.org/10.17848/9781429454865.

Kleiner M. M. and A. B. Krueger (2010), "The Prevalence and Effects of Occupational Licensing," British Journal of Industrial Relations, London School of Economics, Vol. 48(4), pp.676-687, https://doi.org/10.1111/j.1467-8543.2010.00807.x.

Kleiner, M. M. and K. W. Park, (2014) "Life, limbs, and licensing: Occupational regulation, wages, and workplace safety of electricians", Monthly Labor Review, Vol. 2014(1), https://doi.org/10.21916/mlr.2014.1.

Kleiner, M. M. (2016), "Battling over jobs: occupational licensing in health care", American Economic Review, Vol. 106, No. 5, p.p. 165-70.

Kleiner, M. M. (2017), "The influence of occupational licensing and regulation", IZA World of Labor, No. 392, https://doi.org/10.15185/izawol.392.

Kleiner, M. M. and E. Vorotnikov (2017), "Analyzing occupational licensing among the states", Journal of Regulatory Economics, Vol. 52(2), pp.132-158, https://doi.org/10.1007/s11149-017-9333-y.

Koumenta, M and M. Pagliero (2017), "Measuring Prevalence and Labour Markets Impacts of Occupational Regulation in the EU", European Commission.

Koumenta, M., M. Pagliero and D. Rostam-Afschar (2019), "Effects of regulation on service quality. Evidence from six European cases", European Commission, https://doi.org/10.2873/910094.

Mocetti. S., L. Rizzica and G. Roma (2019), "Regulated Occupations in Italy: Extent and Labor Market Effects", Banca d'Italia Occasional Papers, Number 495, April 2019.

NCSL (2018), "Improving Access to Licensed Occupations for Individuals With Criminal Records", Blog Post 7/17/2018, https://www.ncsl.org/research/labor-and-employment/barriers-to-work-individualswith-criminal-records.aspx

OECD (2017), Population Data.

OECD (2018), "OECD Competition Assessment Reviews: Portugal: Volume II - Self-Regulated 
Professions", OECD Publishing, Paris, https://doi.org/10.1787/9789264300606-en.

Osheroff, Y. and M Kleiner (2019), "Occupational Licensing in Israel”, Aaron Institute for Economic Policy Paper, 01.2019, January 2019.

Pagliero, M. (2019), “Occupational Licensing in the EU: Protecting Consumers or Limiting Competition?”, Review of Industrial Organisation, Vol. 55(1), pp 137-153, https://link.springer.com/article/10.1007\%2Fs11151-019-09711-8

Pelkmans, J. (2017), "The New Restrictiveness Indicator for Professional Services: An Assessment", European Parliament, Policy Department A: Economic and Scientific Policy, http://www.europarl.europa.eu/RegData/etudes/STUD/2017/607349/IPOL STU(2017)607349 EN.pdf

PMR (2018), Indicators of Product Market Regulation (database), OECD, available at http://www.oecd.org/economy/reform/indicators-of-product-market-regulation/

Powell, B. and E. Vorotnikov (2015), "Real Estate Continuing Education: Rent Seeking or Improvement in Service Quality?", Eastern Economic Journal, Vol. 38, No. 1, pp.57-73, https://doi.org/10.1057/eej.2010.51.

R.A. Malatest \& Associates Ltd. (2010), "Getting your professional license in Ontario: the experiences of international and Canadian applicants", http://www.fairnesscommissioner.ca/files docs/content/pdf/en/Getting Your Professional Licence in Ontario-The Experiences of International and Canadian Applicants.pdf.

South Africa Government Gazette Act No. 22 of 2019, available at https://www.gov.za/sites/default/files/gcis document/201910/42746gon1295.pdf

Statistics Canada (2019), Quarterly Population Estimates.

STATS SA (2019), Quarterly Labour Force Survey, http://www.statssa.gov.za/publications/P0211/P02114thQuarter2018.pdf.

Supreme Court of the United States (2014), "North Carolina State Board of Dental Examiners v. Federal Trade Commission", https://www.supremecourt.gov/opinions/14pdf/13-534 19m2.pdf.

Vitale, C. (2014), "Competition Issues in the Distribution of Pharmaceuticals", OECD Global Forum on Competition.

Vitale C., C. Moiso, R. Bitteti, R. Danitz, and I. Wanner (forthcoming), "The 2018 edition of the OECD PMR indicators and database - methodological improvements and policy", Economics Department Working paper, OECD Publishing.

Zhang, T. (2017), "The Regulation of Occupations and Labour Market Outcomes in Canada: Three Essays on the Relationship between Occupational Licensing, Earnings, and Internal Labour Mobility". 


\section{Annex A. Additional descriptive statistics}

Figure A.1. The cross-country or cross-state variability of regulations differs significantly across occupations

Panel A: Personal services

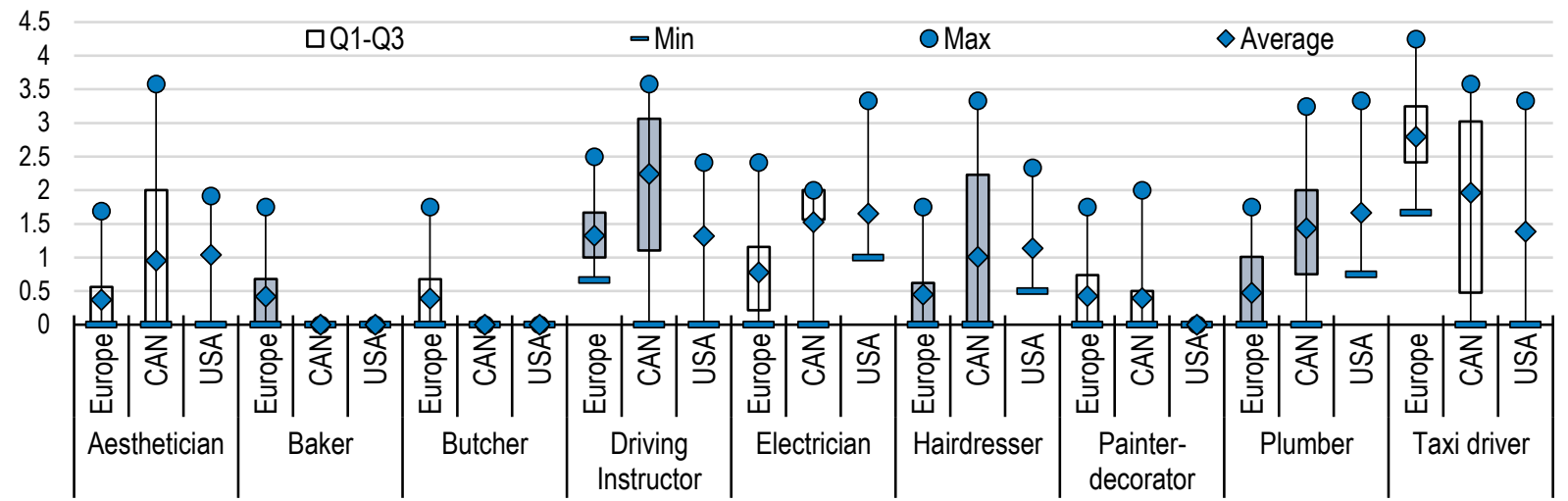

Panel B: Professional services

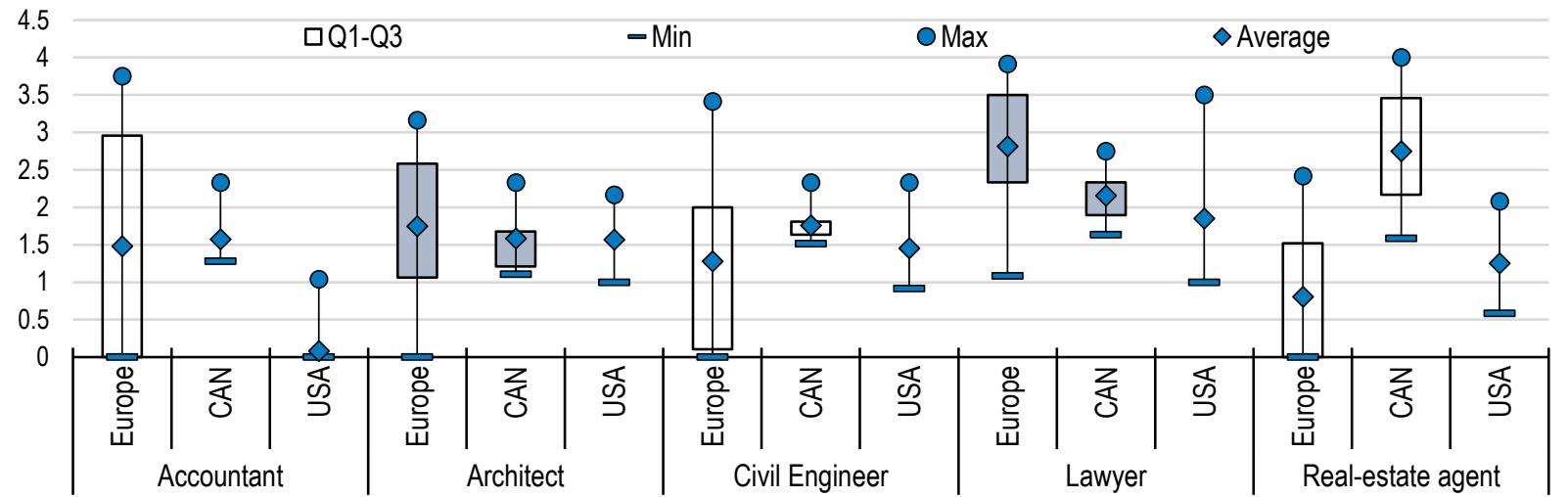

Note: OECD OER indicator value of 0 indicates the absence of regulations and 6 reflects a fully regulated market. Regulations for Canada and US are measured at province/state level. The European sample includes Austria, Belgium, Finland, France, Germany, Hungary, Iceland, Italy, Poland, Portugal, Slovenia, Spain, Sweden, Switzerland, and the United Kingdom.

Source: OECD OER database. To download this graph, please visit https://bit.ly/2w4MR2X 
Figure A.2. Population weighted average OER values

Panel A: Personal services

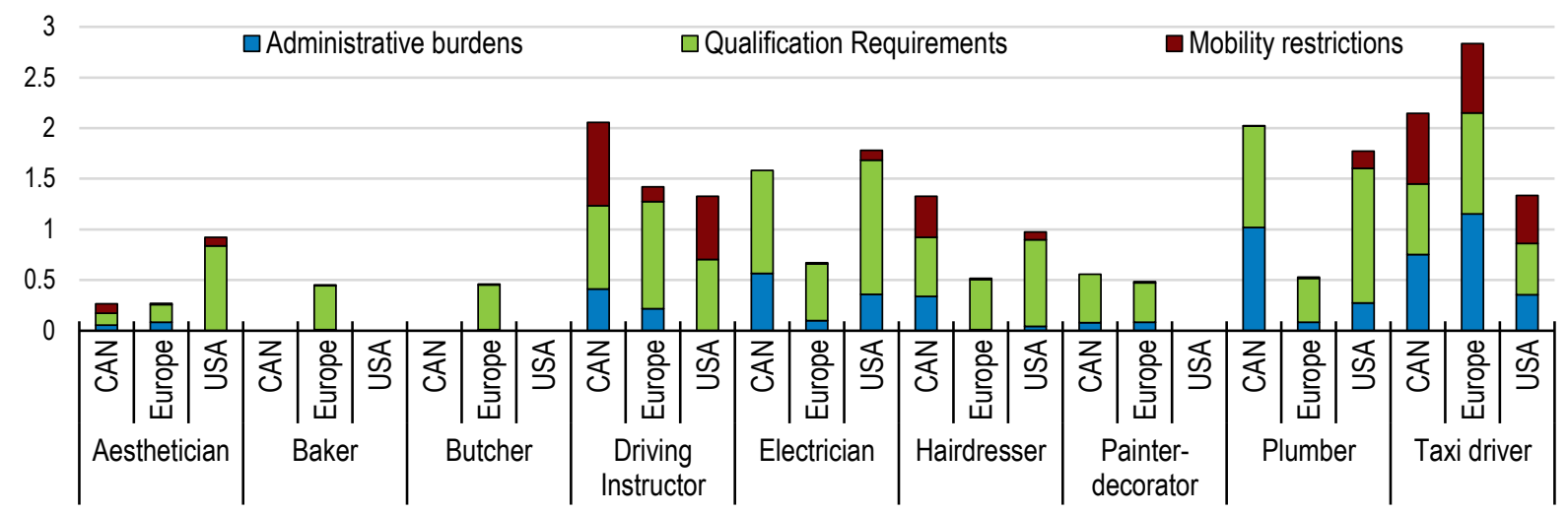

Panel B: Professional services

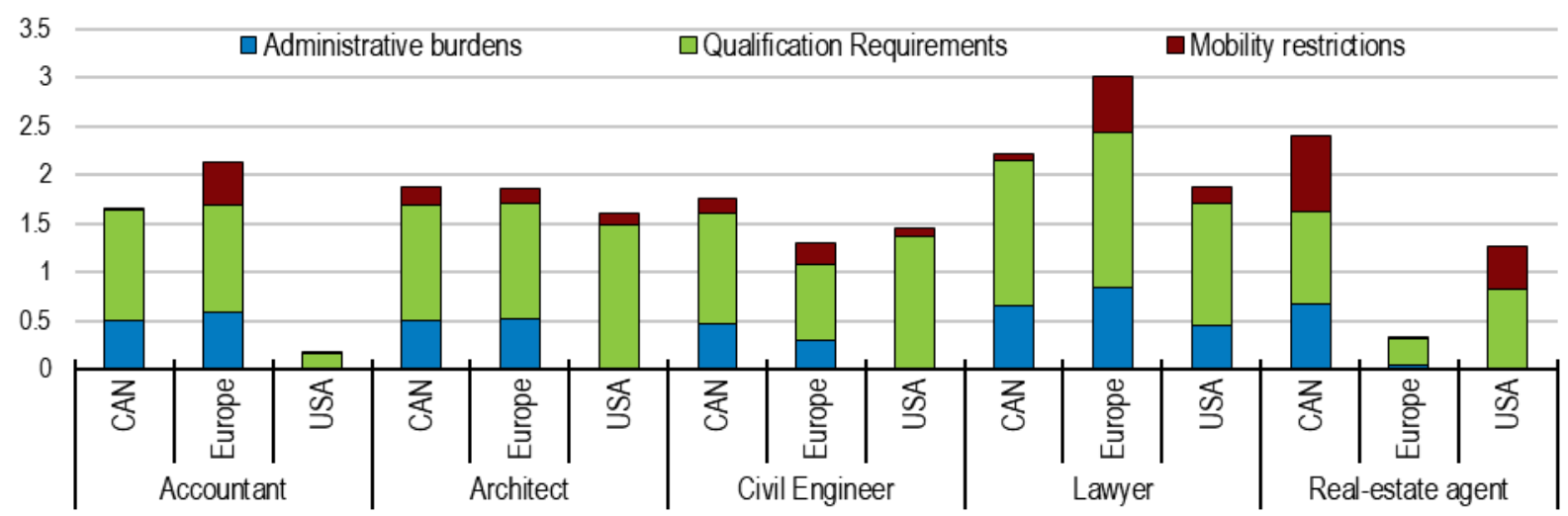

Note: An indicator value of 0 indicates the absence of regulations, 6 reflects a fully regulated market. The graph displays unweighted average OER levels of all US states

Regulations for Canada and US are measured at province/state level. The European sample includes Austria, Belgium, Finland, France, Germany, Hungary, Iceland, Italy, Poland, Portugal, Slovenia, Spain, Sweden, Switzerland, and the United Kingdom.

Source: OECD OER database. Population data for the US (2019) is sourced from the Census Bureau, for Canada (2019) from Statistics Canada, and for Europe (2017) from OECD population database. To download this graph, please visit https://bit.ly/2w4MR2X 


\section{Annex B. Description of the core activities of the professions included in the analysis}

Table B.1. Core activities by occupation

\begin{tabular}{|c|c|}
\hline Occupation & Core activities \\
\hline Aesthetician & $\begin{array}{l}\text { Massaging, cleansing, stimulating or performing similar work with hands or mechanical or electrical apparatus or by use of } \\
\text { cosmetic preparations, tonics, lotions or creams } \\
\text { Giving skincare } \\
\text { Application of artificial eyelashes, make-up } \\
\text { Manicure and pedicure } \\
\text { Removal of superfluous hair by tweezing, depilatories or waxing }\end{array}$ \\
\hline Architect & $\begin{array}{l}\text { Feasibility studies } \\
\text { Design and planning } \\
\text { Representation for obtaining permits (signature of designs) } \\
\text { Tender and contract administration } \\
\text { Expert witness activities (such as a court expert) } \\
\text { Preparation/submission/signing of technical control and compliance documentation or certification of project and adhering } \\
\text { to building legislation/standards of performance, quality, cost and safety }\end{array}$ \\
\hline Accountant & $\begin{array}{l}\text { Book-keeping/Drawing up annual financial statements and consolidated financial statements for undertakings } \\
\text { Insolvency practice } \\
\text { Tax advice } \\
\text { Payroll services } \\
\text { Representation and assistance before administrative authorities (Tax authorities) } \\
\text { Expert witness in accounting matters } \\
\text { Valuation and actuarial services } \\
\text { Investment advice } \\
\text { Management consultancy, including financial planning } \\
\text { This class excludes auditors }\end{array}$ \\
\hline Baker & Retail sale of bread, cakes, flour confectionery and sugar confectionery in specialised stores \\
\hline Butcher & $\begin{array}{l}\text { Retail sale of meat and meat products in specialised stores } \\
\text { This class includes: } \\
\text { - retail sale of meat and meat products (including poultry) }\end{array}$ \\
\hline Taxi driver & $\begin{array}{l}\text { Taxi operation } \\
\text { This class excludes ride-hauling services (e.g. Uber, Lift) }\end{array}$ \\
\hline Civil Engineer & $\begin{array}{l}\text { Feasibility studies } \\
\text { Environmental assessments } \\
\text { Design and planning } \\
\text { Representation for obtaining permits (signature of designs) } \\
\text { Tender and contract administration } \\
\text { Expert witness activities (such as a court expert) } \\
\text { Preparation/submission/signing of technical control and compliance documentation or certification of project and adhering } \\
\text { to building legislation/standards of performance, quality, cost and safety } \\
\text { Managing and Supervising the execution of construction work, including supervision of other related professionals }\end{array}$ \\
\hline & $\begin{array}{l}\text { Construction cost management } \\
\text { Topographical determination, demarcation, land surveying }\end{array}$ \\
\hline
\end{tabular}




\begin{tabular}{|c|c|}
\hline $\begin{array}{l}\text { Driving } \\
\text { Instructor }\end{array}$ & $\begin{array}{l}\text { Driving school activities (training for category B licence or equivalent) } \\
\text { This class excludes: } \\
\text { - driving schools for occupational drivers }\end{array}$ \\
\hline Electrician & $\begin{array}{l}\text { This class includes the installation of electrical systems in all kinds of buildings and civil engineering structures of electrical } \\
\text { systems. } \\
\text { This class includes: } \\
\text { - installation of: } \\
\text { electrical wiring and fittings, telecommunications wiring, computer network and cable television wiring, including fibre optic, } \\
\text { satellite dishes, lighting systems, fire alarms, burglar alarm systems, street lighting and electrical signals, airport runway } \\
\text { lighting electric solar energy collectors. } \\
\text { This class also includes: } \\
\text { - connecting of electric appliances and household equipment, including baseboard heating } \\
\text { This class excludes: } \\
\text { - construction of communications and power transmission lines. } \\
\text { - monitoring and remote monitoring of electronic security systems, such as burglar alarms and fire alarms, including their } \\
\text { installation and maintenance. }\end{array}$ \\
\hline Hairdresser & $\begin{array}{l}\text { This class includes: } \\
\text { - hair washing, trimming and cutting, setting, dyeing, tinting, waving, straightening and similar activities for } \\
\text { men and women } \\
\text { - shaving and beard trimming } \\
\text { - facial massage, manicure and pedicure, make-up etc. } \\
\text { This class excludes: } \\
\text { - manufacture of wigs }\end{array}$ \\
\hline Lawyer & $\begin{array}{l}\text { Representation of clients before courts (sometimes referred to as rights of audience) } \\
\text { Representation before administrative agencies, including on tax matters } \\
\text { Drawing up legal documents (such as contracts and wills) } \\
\text { Advice on matters predominantly regulated by domestic law } \\
\text { Advice on matters predominantly regulated by international law } \\
\text { Advice on matters predominantly regulated by foreign law } \\
\text { Transferring of title to real estate (conveyancing) } \\
\text { Regulation of family matters } \\
\text { Tax advice } \\
\text { Insolvency practice } \\
\text { Management consulting and other business advisory services } \\
\text { Advice and representation on patent law } \\
\text { Business incorporation } \\
\text { Administering oaths and certificating legal documents }\end{array}$ \\
\hline $\begin{array}{l}\text { General care } \\
\text { nurse }\end{array}$ & $\begin{array}{l}\text { This class includes the performance of nursing duties, including assessing patients' need for care, planning, organising, } \\
\text { administering and documenting care, evaluating care, assuring and improving the quality of care, advising, instructing, and } \\
\text { supporting patients and caregivers as they come to terms with the individual patients' medical condition and health situation }\end{array}$ \\
\hline $\begin{array}{l}\text { Painter- } \\
\text { decorator }\end{array}$ & $\begin{array}{l}\text { This class includes: } \\
\text { - interior and exterior painting of buildings } \\
\text { - painting of civil engineering structures } \\
\text { - installation of glass, mirrors, etc. } \\
\text { This class excludes: } \\
\text { - installation of windows }\end{array}$ \\
\hline Plumber & $\begin{array}{l}\text { This class includes the installation of plumbing, heating and air-conditioning systems, including additions, alterations, } \\
\text { maintenance and repair. } \\
\text { This class includes: } \\
\text { installation in buildings or other construction projects of: } \\
\text { heating systems (electric, gas and oil) } \\
\text { furnaces, cooling towers } \\
\text { non-electric solar energy collectors } \\
\text { plumbing and sanitary equipment } \\
\text { ventilation and air-conditioning equipment and ducts }\end{array}$ \\
\hline
\end{tabular}


42 | ECO/WKP(2020)14

\begin{tabular}{ll}
\hline & gas fittings \\
& steam piping \\
& fire sprinkler systems \\
& lawn sprinkler systems \\
& duct work installation \\
& This class excludes: \\
& - installation of electric baseboard heating \\
Real-estate & Facilitating contacts and negotiations between prospective buyers/tenants and owners, and arranging the sale, purchase, \\
agent & rental and lease of real estate property \\
& Obtaining information about properties to be sold or leased \\
& Showing properties to be sold or leased to prospective buyers/tenants and explaining terms of sale or conditions of rent or \\
& lease \\
& Transferring of title to real estate (conveyancing) \\
& Drawing up leasing agreements \\
\hline
\end{tabular}

Source: ISCO-08 (2012) and PMR (2018). 


\section{Annex C. Detailed weighting scheme of the OER indicator}

1. In order to simplify cross-country and cross-state comparisons, the final indicator is scaled to take values between 0 (no regulation) and 6 (fully regulated). To this end, we aggregate the scores of each subindicator using equal weights, before we discount the total value based on the prevalent type of regulation (i.e. multiplied by 0.7 or 0.5 if only a supervisor is required to obtain a license or in the case of certification, respectively). This specific weighting technique is chosen on transparency grounds and does not reflect the objective importance of each sub-indicator.

2. Table E.1 illustrates the weights chosen for each type of answer, based on which we derive the final Occupational Entry Regulations indicator. Importantly, if the information on one or several questions is missing, the sub-indicator value is calculated as the simple average over all available data points. For example, if data on mandatory traineeship are missing, this question would not be scored. Consequently, the answers for other questions in Qualification Requirements sub-indicator would receive a higher weight ( 0.33 instead of 0.25$)$. If all the answers for a sub-indicator are missing, the sub-indicator receives the highest value (6) (as is done for the OECD PMR Indicator). 


\section{4 | ECO/WKP(2020)14}

Table C.1. Weighting scheme

\begin{tabular}{|c|c|c|c|c|c|c|c|c|c|}
\hline Question & Weight & Coding of data & & & & & & & \\
\hline \multicolumn{10}{|c|}{ I. Administrative burdens ( 0.33$)$} \\
\hline $\begin{array}{l}\text { 1. Limitation to number of authorizations } \\
\text { granted }\end{array}$ & 0.33 & $\begin{array}{c}\text { Yes } \\
6\end{array}$ & $\begin{array}{c}\text { No } \\
0\end{array}$ & Missing & & & & & \\
\hline $\begin{array}{l}\text { 2. Restrictions on territorial validity of } \\
\text { professional qualification }\end{array}$ & 0.33 & $\begin{array}{c}\text { Yes } \\
6\end{array}$ & $\begin{array}{c}\text { No } \\
0\end{array}$ & Missing & & & & & \\
\hline $\begin{array}{l}\text { 3. Compulsory membership or registration in } \\
\text { professional association }\end{array}$ & 0.33 & $\begin{array}{c}\text { Yes } \\
6\end{array}$ & $\begin{array}{c}\text { No } \\
0\end{array}$ & Missing & & & & & \\
\hline \multicolumn{10}{|c|}{ II. Qualification requirements $(0.33)$} \\
\hline 4. Number of pathways to obtain qualification & 0.25 & $\begin{array}{c}\text { Only one } \\
\text { pathway } \\
6 \\
\end{array}$ & $\begin{array}{c}\text { Two pathways } \\
3 \\
\end{array}$ & $\begin{array}{c}\text { Three or more } \\
\text { pathways } \\
0 \\
\end{array}$ & Missing & & & & \\
\hline $\begin{array}{l}\text { 5. Requirement of university degree or } \\
\text { vocational course }\end{array}$ & 0.25 & $\begin{array}{l}\text { No } \\
0\end{array}$ & $\begin{array}{c}\text { Yes, up to } 1 \\
\text { year } \\
1\end{array}$ & $\begin{array}{c}\text { Yes, more } \\
\text { than } 1 \text { year to } \\
2 \text { years } \\
2\end{array}$ & $\begin{array}{c}\text { Yes, more } \\
\text { than } 2 \text { years to } \\
3 \text { years } \\
3\end{array}$ & $\begin{array}{c}\text { Yes, more } \\
\text { than } 3 \text { years to } \\
4 \text { years } \\
4\end{array}$ & $\begin{array}{c}\text { Yes, more } \\
\text { than } 4 \text { years to } \\
5 \text { years } \\
5\end{array}$ & $\begin{array}{c}\text { Yes, more } \\
\text { than } 5 \text { years } \\
6\end{array}$ & Missing \\
\hline $\begin{array}{l}\text { 6. Requirement of compulsory practice } \\
\text { (traineeship) }\end{array}$ & 0.25 & $\begin{array}{c}\text { Yes } \\
6\end{array}$ & $\begin{array}{c}\text { No } \\
0\end{array}$ & Missing & & & & & \\
\hline 7. Mandatory state exam & 0.25 & $\begin{array}{c}\text { Yes } \\
6\end{array}$ & $\begin{array}{c}\text { No } \\
0\end{array}$ & Missing & & & & & \\
\hline \multicolumn{10}{|c|}{ III. Mobility restrictions ( 0.33 ) } \\
\hline $\begin{array}{l}\text { 8. Laws or regulations establish a process for } \\
\text { recognising qualifications gained abroad }\end{array}$ & 0.33 & $\begin{array}{c}\text { Yes } \\
0\end{array}$ & $\begin{array}{l}\text { No } \\
6\end{array}$ & Missing & & & & & \\
\hline 9. Local exam required to practice & 0.33 & $\begin{array}{c}\text { Yes } \\
6\end{array}$ & $\begin{array}{c}\text { No } \\
0\end{array}$ & Missing & & & & & \\
\hline $\begin{array}{l}\text { 10. Nationality or citizenship required to } \\
\text { practice }\end{array}$ & 0.33 & $\begin{array}{c}\text { Yes } \\
6 \\
\end{array}$ & $\begin{array}{c}\text { No } \\
0\end{array}$ & Missing & & & & & \\
\hline
\end{tabular}




\section{Annex D. The OER questionnaire}

Table D.1. Questionnaire

\begin{tabular}{|c|c|c|c|}
\hline $\begin{array}{l}\text { Question } \\
\text { Number }\end{array}$ & Question & Answer & Instructions to be read before answering \\
\hline \multicolumn{4}{|c|}{ Background questions } \\
\hline 1 & Is this profession regulated in this country? & $\begin{array}{l}\text { Yes; } \\
\text { No. }\end{array}$ & \\
\hline 2 & Are there any reserved activities? & $\begin{array}{l}\text { Reserved activities; } \\
\text { No reserved activities. }\end{array}$ & $\begin{array}{l}\text { Definitions: } \\
\text { - A profession has an exclusive right to an activity if it is the only } \\
\text { one allowed to provide the activity. } \\
\text { - A profession has a shared exclusive right when that profession } \\
\text { and a limited number of other professions are the only ones } \\
\text { allowed to provide the activity. For example in some countries, } \\
\text { lawyers and notaries may both have the shared exclusive right to } \\
\text { administer oaths. It may be possible that the right to exercise a } \\
\text { specific activity is shared by the profession with the state. } \\
\text { - There is no exclusive right to an activity if anyone can provide this } \\
\text { activity without having to fulfil any special criteria. }\end{array}$ \\
\hline 3 & Is the professional title protected by the law? & $\begin{array}{l}\text { Yes; } \\
\text { No. }\end{array}$ & $\begin{array}{l}\text { Definition: } \\
\text { - A professional title is a name used to indicate a particular } \\
\text { qualification. A professional title is protected when public } \\
\text { authorities define the conditions for conferring it or give a particular } \\
\text { body (e.g. a professional association) the power to do so and if } \\
\text { they protect the use of that title by imposing fines or other } \\
\text { measures when this is used improperly. A professional title may be } \\
\text { combined with the existence of exclusive or shared exclusive rights } \\
\text { or not. When there are no reserved activities, anyone can exercise } \\
\text { those activities, but the use of the title is restricted to those that } \\
\text { meet the requirements and have been authorized to use it. }\end{array}$ \\
\hline
\end{tabular}


46 | ECO/WKP(2020)14

\begin{tabular}{|c|c|c|c|}
\hline 4 & How is access to the profession regulated? & $\begin{array}{l}\text { License; } \\
\text { Certification; } \\
\text { No regulation. }\end{array}$ & $\begin{array}{l}\text { Definitions: } \\
\text { - Licensing: existence of reserved activities. } \\
\text { - Certification: existence of protection of title but no reserved } \\
\text { activities. }\end{array}$ \\
\hline 5 & Does only a supervisor need to obtain authorisation? & $\begin{array}{l}\text { Yes; } \\
\text { No. }\end{array}$ & $\begin{array}{l}\text { Definition: } \\
\text { It is possible that people can exert the regulated activity so long as } \\
\text { they do so under the supervision of one fully certified/licensed } \\
\text { professional. For example, electricians in Belgium can do electrical } \\
\text { work without holding any qualification provided that they are under } \\
\text { the qualified person's effective and permanent control. }\end{array}$ \\
\hline \multicolumn{4}{|c|}{ Administrative burdens } \\
\hline 6 & $\begin{array}{l}\text { Is the number of professionals allowed to practice in your country } \\
\text { limited by law or self-regulation by professional bodies (or a } \\
\text { combination of the two)? }\end{array}$ & $\begin{array}{l}\text { Yes; } \\
\text { No. }\end{array}$ & \\
\hline 7 & $\begin{array}{l}\text { Are there territorial restrictions to the ability of professionals to } \\
\text { practice within your jurisdiction, imposed by law or self-regulation } \\
\text { by professional bodies (or a combination of the two)? }\end{array}$ & $\begin{array}{l}\text { Yes (there are territorial restrictions); } \\
\text { No (a professional is authorized to practice } \\
\text { anywhere in the jurisdiction). }\end{array}$ & $\begin{array}{l}\text { Instructions: } \\
\text { The question tries to ascertain if a professional can exercise in the } \\
\text { whole jurisdiction or only in parts of the jurisdiction. The answer } \\
\text { should be yes, even if such restrictions can be overcome by taking } \\
\text { additional steps (i.e. taking additional exams, obtaining additional } \\
\text { licences/authorisations, etc.). }\end{array}$ \\
\hline 8 & $\begin{array}{l}\text { Is it compulsory to be a member of a professional association for } \\
\text { an individual in order to legally practice or to obtain the } \\
\text { professional title when this is protected by the law? }\end{array}$ & $\begin{array}{l}\text { Yes; } \\
\text { No. }\end{array}$ & \\
\hline \multicolumn{4}{|c|}{ Qualification requirements } \\
\hline 9 & $\begin{array}{l}\text { How many pathways are there to obtain the qualifications to } \\
\text { legally practice the profession? }\end{array}$ & $\begin{array}{l}\text { One pathway; } \\
\text { Two pathways; } \\
\text { Three or more pathways. }\end{array}$ & $\begin{array}{l}\text { Definition: } \\
\text { A pathway is the process by which a person can obtain the } \\
\text { qualifications to legally practice the profession (e.g., one pathway } \\
\text { may require an undergraduate degree plus } 1 \text { year of compulsory } \\
\text { practice, while another could require a short vocational course and } \\
\text { a much longer period of compulsory practice). }\end{array}$ \\
\hline 10 & $\begin{array}{l}\text { Is an undergraduate university degree or a vocational course } \\
\text { required in order to legally practice or to obtain the professional } \\
\text { title when this is protected by the law, whether this is required by } \\
\text { law or by self-regulation by professional bodies, or a combination } \\
\text { of the two? If so, for how long? }\end{array}$ & $\begin{array}{l}\text { Yes, up to } 1 \text { year; } \\
\text { Yes, more than } 1 \text { year to } 2 \text { years; } \\
\text { Yes, more than } 2 \text { years to } 3 \text { years; } \\
\text { Yes, more than } 3 \text { years to } 4 \text { years; } \\
\text { Yes, more than } 4 \text { years to } 5 \text { years; } \\
\text { Yes, more than } 5 \text { years; } \\
\text { No. }\end{array}$ & \\
\hline
\end{tabular}




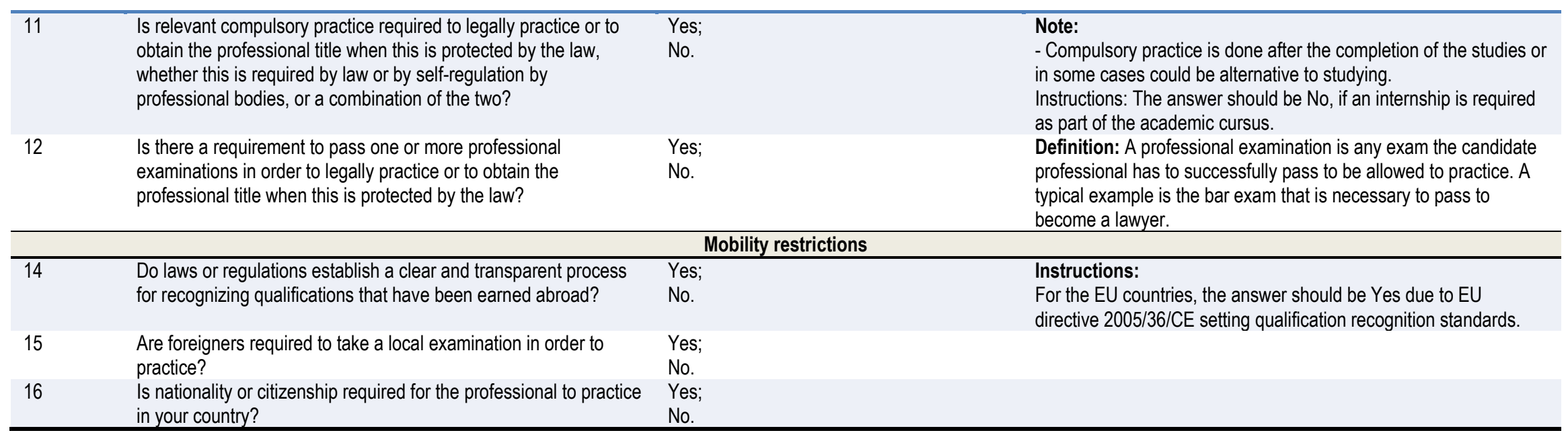




\section{Annex E. Abbreviations of countries, states and provinces}

Table E.1. Abbreviations of countries

\begin{tabular}{l|l|l|l}
\hline Country & Abbreviation & Country & Abbreviation \\
\hline Austria & AUT & Italy & ITA \\
\hline Belgium & BEL & Poland & POL \\
\hline Canada & CAN & Portugal & PRT \\
\hline Finland & FIN & Slovenia & SVN \\
\hline France & FRA & South Africa & ZAF \\
\hline Germany & DEU & Spain & ESP \\
\hline Hungary & HUN & Sweden & SWE \\
\hline Iceland & ISL & Switzerland & CHE \\
\hline India & IND & United Kingdom & GBR \\
\hline Israel & ISR & United States & USA/US \\
\hline
\end{tabular}

Table E.2. Abbreviations of US states

\begin{tabular}{|c|c|c|c|}
\hline State & Abbreviation & State & Abbreviation \\
\hline Alabama & $\mathrm{AL}$ & \multirow{26}{*}{$\begin{array}{l}\text { Missouri } \\
\text { Montana } \\
\text { Nebraska } \\
\text { Nevada } \\
\text { New Hampshire } \\
\text { New Jersey } \\
\text { New Mexico } \\
\text { New York } \\
\text { North Carolina } \\
\text { North Dakota } \\
\text { Ohio } \\
\text { Oklahoma } \\
\text { Oregon } \\
\text { Pennsylvania } \\
\text { Rhode Island } \\
\text { South Carolina } \\
\text { South Dakota } \\
\text { Tennessee } \\
\text { Texas } \\
\text { Utah } \\
\text { Vermont } \\
\text { Virginia } \\
\text { Washington } \\
\text { West Virginia } \\
\text { Wisconsin } \\
\text { Wyoming }\end{array}$} & MO \\
\hline Alaska & AK & & MT \\
\hline Arizona & $A Z$ & & $\mathrm{NE}$ \\
\hline Arkansas & $\mathrm{AR}$ & & NV \\
\hline California & $\mathrm{CA}$ & & $\mathrm{NH}$ \\
\hline Colorado & $\mathrm{CO}$ & & $\mathrm{NJ}$ \\
\hline Connecticut & CT & & NM \\
\hline Delaware & $\mathrm{DE}$ & & NY \\
\hline $\begin{array}{l}\text { District of } \\
\text { Columbia }\end{array}$ & $\mathrm{DC}$ & & $\mathrm{NC}$ \\
\hline Florida & $\mathrm{FL}$ & & ND \\
\hline Georgia & $\mathrm{GA}$ & & $\mathrm{OH}$ \\
\hline Hawaii & $\mathrm{HI}$ & & OK \\
\hline Idaho & ID & & OR \\
\hline Illinois & IL & & PA \\
\hline Indiana & IN & & $\mathrm{Rl}$ \\
\hline lowa & $\mathrm{IA}$ & & SC \\
\hline Kansas & KS & & SD \\
\hline Kentucky & KY & & $\mathrm{TN}$ \\
\hline Louisiana & LA & & $\mathrm{TX}$ \\
\hline Maine & $\mathrm{ME}$ & & UT \\
\hline Maryland & MD & & VT \\
\hline Massachusetts & MA & & VA \\
\hline Michigan & Ml & & WA \\
\hline Minnesota & MN & & WV \\
\hline Mississippi & MS & & WI \\
\hline & & & WY \\
\hline
\end{tabular}


Table E.3. Abbreviations of Canadian provinces

\begin{tabular}{l|l}
\hline Province & Abbreviation \\
\hline Alberta & $\mathrm{AB}$ \\
\hline British Columbia & $\mathrm{BC}$ \\
\hline Manitoba & $\mathrm{MB}$ \\
\hline New Brunswick & $\mathrm{NB}$ \\
\hline Newfoundland and Labrador & $\mathrm{NFL}$ \\
\hline Nova Scotia & $\mathrm{NS}$ \\
\hline Ontario & $\mathrm{ON}$ \\
\hline Prince Edward Island & $\mathrm{PEI}$ \\
\hline Quebec & $\mathrm{QC}$ \\
\hline Saskatchewan & $\mathrm{SK}$ \\
\hline
\end{tabular}




\section{Annex F. Comparison of the indicators measuring occupational regulations}

Table F.1. Comparison of the indicators measuring occupational regulations

\begin{tabular}{|c|c|c|c|c|}
\hline Element included in the indicator & $\begin{array}{c}\text { OECD } \\
\text { Occupational } \\
\text { entry } \\
\text { requirements } \\
\text { indicator (OER) }\end{array}$ & $\begin{array}{l}\text { OECD Product } \\
\text { Market } \\
\text { Regulation } \\
\text { indicator for } \\
\text { professional } \\
\text { services }\end{array}$ & $\begin{array}{l}\text { EC indicator on } \\
\text { restrictiveness of } \\
\text { occupational } \\
\text { regulation }\end{array}$ & $\begin{array}{c}\text { EC } \\
\text { indicator on } \\
\text { barriers in } \\
\text { business } \\
\text { services }\end{array}$ \\
\hline \multicolumn{5}{|c|}{ The type of regulation } \\
\hline License (reserves of activities and protected title) & $\checkmark$ & & & \\
\hline Certification (only protected title) & $\checkmark$ & & & \\
\hline Only a supervisor is required to obtain authorisation & $\checkmark$ & & & \\
\hline \multicolumn{5}{|c|}{ Reserved activities and title } \\
\hline Exclusive or shared reserved activities & & $\checkmark$ & $\checkmark$ & $\checkmark$ \\
\hline Protection of title & & $\checkmark$ & $\checkmark$ & \\
\hline \multicolumn{5}{|c|}{ Administrative burdens } \\
\hline Limitation to number of authorisations granted & $\checkmark$ & $\checkmark$ & $\checkmark$ & \\
\hline Territorial validity of professional qualification & $\checkmark$ & $\checkmark$ & $\checkmark$ & $\checkmark$ \\
\hline $\begin{array}{l}\text { Compulsory membership or registration in professional } \\
\text { association }\end{array}$ & $\checkmark$ & $\checkmark$ & $\checkmark$ & $\checkmark$ \\
\hline Requirement of renewal & $\checkmark$ & & & $\checkmark$ \\
\hline Age restriction & & & $\checkmark$ & \\
\hline Authorisation procedures for (companies/ professionals) & & & & $\checkmark$ \\
\hline Existence of mutual recognition clause & & & & $\checkmark$ \\
\hline Tacit approval & & & & $\checkmark$ \\
\hline $\begin{array}{l}\text { Requirements for temporary cross-border service provision } \\
\text { (companies/professionals) }\end{array}$ & & & & $\checkmark$ \\
\hline \multicolumn{5}{|c|}{ Qualification requirements } \\
\hline Number of pathways to obtain qualification & $\checkmark$ & $\checkmark$ & $\checkmark$ & \\
\hline Requirement of university degree or vocational course & $\checkmark$ & $\checkmark$ & $\checkmark$ & \\
\hline Requirement of compulsory practice (traineeship) & $\checkmark$ & $\checkmark$ & $\checkmark$ & \\
\hline Mandatory state exam & $\checkmark$ & $\checkmark$ & $\checkmark$ & \\
\hline $\begin{array}{l}\text { Obligation to have professional experience to get full capacity } \\
\text { Continuous professional development obligations }\end{array}$ & & & $\checkmark$ & \\
\hline \multicolumn{5}{|c|}{ Mobility restrictions } \\
\hline $\begin{array}{l}\text { Laws or regulations establish a process for recognising } \\
\text { qualifications gained abroad }\end{array}$ & $\checkmark$ & $\checkmark$ & & \\
\hline Local exam required to practice & $\checkmark$ & $\checkmark$ & & \\
\hline Nationality or citizenship required to practice & $\checkmark$ & $\checkmark$ & & \\
\hline Engagement in Mutual Recognition Agreements (MRA) & & $\checkmark$ & & \\
\hline \multicolumn{5}{|c|}{ Conduct regulation/ Exercise requirements } \\
\hline Tariff/fees restrictions & & $\checkmark$ & $\checkmark$ & $\checkmark$ \\
\hline Restrictions on advertising & & $\checkmark$ & $\checkmark$ & $\checkmark$ \\
\hline Restriction on legal form & & $\checkmark$ & $\checkmark$ & $\checkmark$ \\
\hline Restriction on inter-professional cooperation & & $\checkmark$ & $\checkmark$ & $\checkmark$ \\
\hline
\end{tabular}


ECO/WKP(2020)14 | 51

\begin{tabular}{|c|c|c|c|}
\hline Restrictions on ownership rights & $\checkmark$ & $\checkmark$ & $\checkmark$ \\
\hline Voting rights control & $\checkmark$ & $\checkmark$ & $\checkmark$ \\
\hline Incompatibilities of activities for a professional & & $\checkmark$ & \\
\hline Professional indemnity insurance & & $\checkmark$ & $\checkmark$ \\
\hline Authorisation requirements & & $\checkmark$ & $\checkmark$ \\
\hline Points of Single Contact & & & $\checkmark$ \\
\hline
\end{tabular}

Note: The OECD PMR Indicator refers to the 2018 vintage of the Product Market Regulation indicator.

Source: Pelkmans (2017), European Commission (2015). OECD OER database. 


\section{Annex G. Values of OER indicator}

Table G.1. Values of OER indicator

\begin{tabular}{|c|c|c|c|c|c|c|c|c|c|c|c|c|c|c|c|}
\hline $\begin{array}{l}\text { 롷응 } \\
\text { 응 }\end{array}$ & 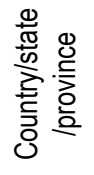 & $\stackrel{\Perp}{\stackrel{2}{二}}$ & 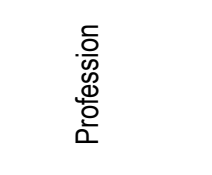 & 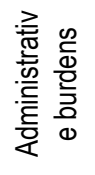 & 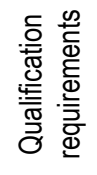 & $\frac{\mathscr{0}}{\frac{0}{0}}$ & 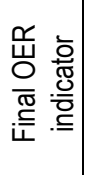 & 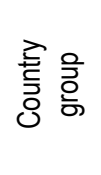 & 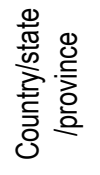 & $\stackrel{\otimes}{\stackrel{亠}{二}}$ & 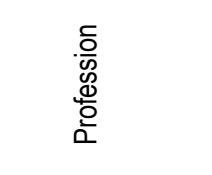 & 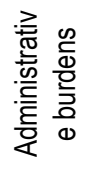 & 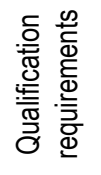 & 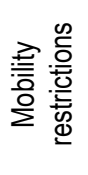 & 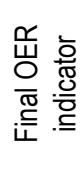 \\
\hline CAN & $A B$ & Professional & Accountant & 0.47 & 0.82 & 0.00 & 1.28 & US & ID & Professional & Accountant & 0.00 & 0.00 & 0.00 & 0.00 \\
\hline CAN & $A B$ & Professional & Architect & 0.47 & 0.88 & 0.00 & 1.34 & US & ID & Professional & Architect & 0.00 & 1.50 & 0.00 & 1.50 \\
\hline CAN & $A B$ & Professional & Civil engineer & 0.47 & 1.23 & 0.47 & 2.16 & US & ID & Professional & Civil engineer & 0.00 & 1.42 & 0.00 & 1.42 \\
\hline CAN & $A B$ & Professional & Lawyer & 0.67 & 1.42 & 0.67 & 2.75 & US & ID & Professional & Lawyer & 0.67 & 1.00 & 0.00 & 1.67 \\
\hline CAN & $A B$ & Professional & Real-estate agent & 0.67 & 0.92 & 0.00 & 1.58 & US & ID & Professional & Real-estate agent & 0.00 & 0.83 & 0.67 & 1.50 \\
\hline CAN & $A B$ & Personal & Aesthetician & 0.00 & 0.00 & 0.00 & 0.00 & US & ID & Personal & Aesthetician & 0.00 & 1.00 & 0.00 & 1.00 \\
\hline CAN & $A B$ & Personal & Baker & 0.00 & 0.00 & 0.00 & 0.00 & US & ID & Personal & Baker & 0.00 & 0.00 & 0.00 & 0.00 \\
\hline CAN & $A B$ & Personal & Butcher & 0.00 & 0.00 & 0.00 & 0.00 & US & ID & Personal & Butcher & 0.00 & 0.00 & 0.00 & 0.00 \\
\hline CAN & $A B$ & Personal & Driving instructor & 0.67 & 1.58 & 1.33 & 3.58 & US & ID & Personal & Driving instructor & 0.00 & 0.08 & 0.00 & 0.08 \\
\hline CAN & $A B$ & Personal & Electrician & 0.67 & 1.33 & 0.00 & 2.00 & US & ID & Personal & Electrician & 0.00 & 1.42 & 0.00 & 1.42 \\
\hline CAN & $A B$ & Personal & Hairdresser & 0.33 & 0.67 & 0.67 & 1.67 & US & ID & Personal & Hairdresser & 0.00 & 1.00 & 0.00 & 1.00 \\
\hline CAN & $A B$ & Personal & Painter-decorator & 0.67 & 1.33 & 0.00 & 2.00 & US & ID & Personal & Painter-decorator & 0.00 & 0.00 & 0.00 & 0.00 \\
\hline CAN & $A B$ & Personal & Plumber & 0.33 & 0.67 & 0.00 & 1.00 & US & ID & Personal & Plumber & 0.00 & 1.67 & 0.00 & 1.67 \\
\hline CAN & $A B$ & Personal & Taxi driver & 0.00 & 0.00 & 0.00 & 0.00 & US & ID & Personal & Taxi driver & 0.67 & 0.50 & 0.67 & 1.83 \\
\hline CAN & $A B$ & Nurse & Nurse & 0.67 & 1.67 & 0.00 & 2.33 & US & ID & Nurse & Nurse & 0.00 & 0.92 & 0.67 & 1.58 \\
\hline CAN & $\mathrm{BC}$ & Professional & Accountant & 0.47 & 0.99 & 0.00 & 1.46 & US & IL & Professional & Accountant & 0.00 & 0.00 & 0.00 & 0.00 \\
\hline CAN & $\mathrm{BC}$ & Professional & Architect & 0.47 & 0.64 & 0.00 & 1.11 & US & $\mathrm{IL}$ & Professional & Architect & 0.00 & 1.50 & 0.00 & 1.50 \\
\hline CAN & $\mathrm{BC}$ & Professional & Civil engineer & 0.47 & 1.17 & 0.00 & 1.63 & US & $\mathrm{IL}$ & Professional & Civil engineer & 0.00 & 1.42 & 0.00 & 1.42 \\
\hline CAN & $\mathrm{BC}$ & Professional & Lawyer & 0.67 & 1.42 & 0.00 & 2.08 & US & $\mathrm{IL}$ & Professional & Lawyer & 0.00 & 1.25 & 0.00 & 1.25 \\
\hline CAN & $\mathrm{BC}$ & Professional & Real-estate agent & 0.67 & 0.92 & 0.67 & 2.25 & US & $\mathrm{IL}$ & Professional & Real-estate agent & 0.00 & 0.83 & 0.67 & 1.50 \\
\hline CAN & $\mathrm{BC}$ & Personal & Aesthetician & 0.00 & 0.00 & 0.00 & 0.00 & US & IL & Personal & Aesthetician & 0.00 & 0.58 & 0.00 & 0.58 \\
\hline CAN & $B C$ & Personal & Baker & 0.00 & 0.00 & 0.00 & 0.00 & US & $\mathrm{IL}$ & Personal & Baker & 0.00 & 0.00 & 0.00 & 0.00 \\
\hline CAN & $\mathrm{BC}$ & Personal & Butcher & 0.00 & 0.00 & 0.00 & 0.00 & US & $\mathrm{IL}$ & Personal & Butcher & 0.00 & 0.00 & 0.00 & 0.00 \\
\hline
\end{tabular}


ECO/WKP(2020)14 | 53

\begin{tabular}{|c|c|c|c|c|c|c|c|c|c|c|c|c|c|c|c|}
\hline CAN & $B C$ & Personal & Driving instructor & 0.00 & 0.83 & 0.00 & 0.83 & US & $\mathrm{IL}$ & Personal & Driving instructor & 0.00 & 1.33 & 0.67 & 2.00 \\
\hline CAN & $\mathrm{BC}$ & Personal & Electrician & 0.00 & 0.00 & 0.00 & 0.00 & US & IL & Personal & Electrician & 0.67 & 1.25 & 0.00 & 1.92 \\
\hline CAN & $\mathrm{BC}$ & Personal & Hairdresser & 0.00 & 0.00 & 0.00 & 0.00 & US & $\mathrm{IL}$ & Personal & Hairdresser & 0.00 & 0.58 & 0.00 & 0.58 \\
\hline CAN & $\mathrm{BC}$ & Personal & Painter-decorator & 0.00 & 0.00 & 0.00 & 0.00 & US & IL & Personal & Painter-decorator & 0.00 & 0.00 & 0.00 & 0.00 \\
\hline CAN & $\mathrm{BC}$ & Personal & Plumber & 0.00 & 0.00 & 0.00 & 0.00 & US & IL & Personal & Plumber & 0.67 & 1.00 & 0.00 & 1.67 \\
\hline CAN & $\mathrm{BC}$ & Personal & Taxi driver & 0.00 & 0.00 & 0.00 & 0.00 & US & IL & Personal & Taxi driver & 0.00 & 0.00 & 0.00 & 0.00 \\
\hline CAN & $\mathrm{BC}$ & Nurse & Nurse & 0.67 & 1.08 & 0.00 & 1.75 & US & $\mathrm{IL}$ & Nurse & Nurse & 0.00 & 0.92 & 0.00 & 0.92 \\
\hline CAN & MB & Professional & Accountant & 0.47 & 0.99 & 0.00 & 1.46 & US & IN & Professional & Accountant & 0.00 & 0.00 & 0.00 & 0.00 \\
\hline CAN & $\mathrm{MB}$ & Professional & Architect & 0.47 & 1.23 & 0.00 & 1.69 & US & IN & Professional & Architect & 0.00 & 1.50 & 0.00 & 1.50 \\
\hline CAN & MB & Professional & Civil engineer & 0.47 & 1.11 & 0.00 & 1.58 & US & IN & Professional & Civil engineer & 0.00 & 1.42 & 0.00 & 1.42 \\
\hline CAN & $\mathrm{MB}$ & Professional & Lawyer & 0.67 & 1.67 & 0.00 & 2.33 & US & IN & Professional & Lawyer & 0.67 & 1.50 & 0.00 & 2.17 \\
\hline CAN & MB & Professional & Real-estate agent & 0.67 & 0.83 & 0.67 & 2.17 & US & IN & Professional & Real-estate agent & 0.00 & 0.83 & 0.67 & 1.50 \\
\hline CAN & $\mathrm{MB}$ & Personal & Aesthetician & 0.67 & 1.33 & 1.33 & 3.33 & US & IN & Personal & Aesthetician & 0.00 & 0.83 & 0.00 & 0.83 \\
\hline CAN & $\mathrm{MB}$ & Personal & Baker & 0.00 & 0.00 & 0.00 & 0.00 & US & IN & Personal & Baker & 0.00 & 0.00 & 0.00 & 0.00 \\
\hline CAN & MB & Personal & Butcher & 0.00 & 0.00 & 0.00 & 0.00 & US & IN & Personal & Butcher & 0.00 & 0.00 & 0.00 & 0.00 \\
\hline CAN & $\mathrm{MB}$ & Personal & Driving instructor & 0.67 & 1.08 & 1.33 & 3.08 & US & IN & Personal & Driving instructor & 0.00 & 0.33 & 0.67 & 1.00 \\
\hline CAN & MB & Personal & Electrician & 0.67 & 1.33 & 0.00 & 2.00 & US & IN & Personal & Electrician & 0.67 & 1.25 & 0.00 & 1.92 \\
\hline CAN & $\mathrm{MB}$ & Personal & Hairdresser & 0.67 & 1.33 & 1.33 & 3.33 & US & IN & Personal & Hairdresser & 0.00 & 0.83 & 0.00 & 0.83 \\
\hline CAN & $\mathrm{MB}$ & Personal & Painter-decorator & 0.00 & 0.00 & 0.00 & 0.00 & US & IN & Personal & Painter-decorator & 0.00 & 0.00 & 0.00 & 0.00 \\
\hline CAN & MB & Personal & Plumber & 0.00 & 0.67 & 0.00 & 0.67 & US & IN & Personal & Plumber & 0.00 & 1.00 & 0.00 & 1.00 \\
\hline CAN & $\mathrm{MB}$ & Personal & Taxi driver & 1.33 & 0.58 & 1.33 & 3.25 & US & IN & Personal & Taxi driver & 0.00 & 1.00 & 0.67 & 1.67 \\
\hline CAN & MB & Nurse & Nurse & 0.67 & 1.17 & 0.00 & 1.83 & US & IN & Nurse & Nurse & 0.00 & 0.92 & 0.00 & 0.92 \\
\hline CAN & NB & Professional & Accountant & 0.47 & 0.99 & 0.47 & 1.93 & US & KS & Professional & Accountant & 0.00 & 0.00 & 0.00 & 0.00 \\
\hline CAN & NB & Professional & Architect & 0.47 & 1.17 & 0.00 & 1.63 & US & KS & Professional & Architect & 0.00 & 1.50 & 0.00 & 1.50 \\
\hline CAN & NB & Professional & Civil engineer & 0.47 & 1.17 & 0.00 & 1.63 & US & KS & Professional & Civil engineer & 0.00 & 1.67 & 0.00 & 1.67 \\
\hline CAN & NB & Professional & Lawyer & 0.67 & 1.58 & 0.00 & 2.25 & US & KS & Professional & Lawyer & 0.00 & 1.25 & 0.00 & 1.25 \\
\hline CAN & NB & Professional & Real-estate agent & 0.67 & 1.58 & 1.33 & 3.58 & US & KS & Professional & Real-estate agent & 0.00 & 0.83 & 0.67 & 1.50 \\
\hline CAN & NB & Personal & Aesthetician & 0.67 & 1.58 & 1.33 & 3.58 & US & KS & Personal & Aesthetician & 0.00 & 0.83 & 0.67 & 1.50 \\
\hline CAN & NB & Personal & Baker & 0.00 & 0.00 & 0.00 & 0.00 & US & KS & Personal & Baker & 0.00 & 0.00 & 0.00 & 0.00 \\
\hline CAN & NB & Personal & Butcher & 0.00 & 0.00 & 0.00 & 0.00 & US & KS & Personal & Butcher & 0.00 & 0.00 & 0.00 & 0.00 \\
\hline CAN & NB & Personal & Driving instructor & 0.67 & 1.00 & 1.33 & 3.00 & US & KS & Personal & Driving instructor & 0.00 & 0.08 & 0.67 & 0.75 \\
\hline CAN & NB & Personal & Electrician & 0.67 & 1.08 & 0.00 & 1.75 & US & KS & Personal & Electrician & 0.67 & 1.00 & 0.67 & 2.33 \\
\hline CAN & NB & Personal & Hairdresser & 0.00 & 0.00 & 0.00 & 0.00 & US & KS & Personal & Hairdresser & 0.00 & 0.83 & 0.67 & 1.50 \\
\hline CAN & NB & Personal & Painter-decorator & 0.00 & 0.00 & 0.00 & 0.00 & US & KS & Personal & Painter-decorator & 0.00 & 0.00 & 0.00 & 0.00 \\
\hline CAN & NB & Personal & Plumber & 0.67 & 1.08 & 0.00 & 1.75 & US & KS & Personal & Plumber & 0.67 & 1.00 & 0.67 & 2.33 \\
\hline
\end{tabular}


54 | ECO/WKP(2020)14

\begin{tabular}{|c|c|c|c|c|c|c|c|c|c|c|c|c|c|c|c|}
\hline CAN & NB & Personal & Taxi driver & 0.00 & 0.00 & 0.00 & 0.00 & US & KS & Personal & Taxi driver & 0.67 & 0.50 & 0.67 & 1.83 \\
\hline CAN & NB & Nurse & Nurse & 0.67 & 1.17 & 0.00 & 1.83 & US & KS & Nurse & Nurse & 0.00 & 1.42 & 0.00 & 1.42 \\
\hline CAN & NFL & Professional & Accountant & 0.47 & 0.99 & 0.00 & 1.46 & US & KY & Professional & Accountant & 0.00 & 0.00 & 0.00 & 0.00 \\
\hline CAN & NFL & Professional & Architect & 0.00 & 1.17 & 0.00 & 1.17 & US & KY & Professional & Architect & 0.00 & 1.50 & 0.00 & 1.50 \\
\hline CAN & NFL & Professional & Civil engineer & 0.47 & 1.17 & 0.00 & 1.63 & US & KY & Professional & Civil engineer & 0.00 & 1.67 & 0.00 & 1.67 \\
\hline CAN & NFL & Professional & Lawyer & 0.47 & 1.17 & 0.00 & 1.63 & US & KY & Professional & Lawyer & 0.67 & 1.25 & 0.00 & 1.92 \\
\hline CAN & NFL & Professional & Real-estate agent & 0.67 & 1.58 & 1.33 & 3.58 & US & KY & Professional & Real-estate agent & 0.00 & 0.58 & 0.67 & 1.25 \\
\hline CAN & NFL & Personal & Aesthetician & 0.00 & 0.00 & 0.00 & 0.00 & US & $\mathrm{KY}$ & Personal & Aesthetician & 0.00 & 1.08 & 0.00 & 1.08 \\
\hline CAN & NFL & Personal & Baker & 0.00 & 0.00 & 0.00 & 0.00 & US & KY & Personal & Baker & 0.00 & 0.00 & 0.00 & 0.00 \\
\hline CAN & NFL & Personal & Butcher & 0.00 & 0.00 & 0.00 & 0.00 & US & KY & Personal & Butcher & 0.00 & 0.00 & 0.00 & 0.00 \\
\hline CAN & NFL & Personal & Driving instructor & 0.00 & 0.25 & 0.33 & 0.58 & US & KY & Personal & Driving instructor & 0.00 & 1.00 & 0.67 & 1.67 \\
\hline CAN & NFL & Personal & Electrician & 0.00 & 0.00 & 0.00 & 0.00 & US & KY & Personal & Electrician & 0.00 & 1.92 & 0.00 & 1.92 \\
\hline CAN & NFL & Personal & Hairdresser & 0.00 & 0.00 & 0.00 & 0.00 & US & KY & Personal & Hairdresser & 0.00 & 1.08 & 0.00 & 1.08 \\
\hline CAN & NFL & Personal & Painter-decorator & 0.00 & 0.00 & 0.00 & 0.00 & US & KY & Personal & Painter-decorator & 0.00 & 0.00 & 0.00 & 0.00 \\
\hline CAN & NFL & Personal & Plumber & 0.00 & 0.67 & 0.33 & 1.00 & US & KY & Personal & Plumber & 0.00 & 1.50 & 0.00 & 1.50 \\
\hline CAN & NFL & Personal & Taxi driver & 0.67 & 1.08 & 0.67 & 2.42 & US & $\mathrm{KY}$ & Personal & Taxi driver & 0.00 & 0.50 & 0.67 & 1.17 \\
\hline CAN & NFL & Nurse & Nurse & 0.67 & 1.08 & 0.00 & 1.75 & US & KY & Nurse & Nurse & 0.00 & 1.17 & 0.00 & 1.17 \\
\hline CAN & NS & Professional & Accountant & 0.47 & 0.99 & 0.00 & 1.46 & US & LA & Professional & Accountant & 0.00 & 0.00 & 0.00 & 0.00 \\
\hline CAN & NS & Professional & Architect & 0.47 & 1.17 & 0.00 & 1.63 & US & LA & Professional & Architect & 0.00 & 1.50 & 0.00 & 1.50 \\
\hline CAN & NS & Professional & Civil engineer & 0.67 & 1.67 & 0.00 & 2.33 & US & LA & Professional & Civil engineer & 0.00 & 1.42 & 0.00 & 1.42 \\
\hline CAN & NS & Professional & Lawyer & 0.67 & 1.67 & 0.00 & 2.33 & US & LA & Professional & Lawyer & 0.67 & 1.50 & 1.33 & 3.50 \\
\hline CAN & NS & Professional & Real-estate agent & 0.67 & 1.58 & 0.67 & 2.92 & US & LA & Professional & Real-estate agent & 0.00 & 0.58 & 0.00 & 0.58 \\
\hline CAN & NS & Personal & Aesthetician & 0.67 & 1.33 & 0.67 & 2.67 & US & LA & Personal & Aesthetician & 0.00 & 0.83 & 0.67 & 1.50 \\
\hline CAN & NS & Personal & Baker & 0.00 & 0.00 & 0.00 & 0.00 & US & LA & Personal & Baker & 0.00 & 0.00 & 0.00 & 0.00 \\
\hline CAN & NS & Personal & Butcher & 0.00 & 0.00 & 0.00 & 0.00 & US & LA & Personal & Butcher & 0.00 & 0.00 & 0.00 & 0.00 \\
\hline CAN & NS & Personal & Driving instructor & 0.67 & 0.58 & 0.67 & 1.92 & US & LA & Personal & Driving instructor & 0.00 & 0.33 & 0.67 & 1.00 \\
\hline CAN & NS & Personal & Electrician & 0.67 & 1.33 & 0.00 & 2.00 & US & LA & Personal & Electrician & 0.67 & 1.00 & 0.00 & 1.67 \\
\hline CAN & NS & Personal & Hairdresser & 0.67 & 1.33 & 0.67 & 2.67 & US & LA & Personal & Hairdresser & 0.00 & 0.83 & 0.67 & 1.50 \\
\hline CAN & NS & Personal & Painter-decorator & 0.00 & 0.00 & 0.00 & 0.00 & US & LA & Personal & Painter-decorator & 0.00 & 0.00 & 0.00 & 0.00 \\
\hline CAN & NS & Personal & Plumber & 0.67 & 1.33 & 0.00 & 2.00 & US & LA & Personal & Plumber & 0.00 & 1.17 & 0.67 & 1.83 \\
\hline CAN & NS & Personal & Taxi driver & 0.00 & 1.50 & 1.33 & 2.83 & US & LA & Personal & Taxi driver & 0.47 & 2.00 & 0.47 & 2.93 \\
\hline CAN & NS & Nurse & Nurse & 0.67 & 1.17 & 0.67 & 2.50 & US & LA & Nurse & Nurse & 0.00 & 0.92 & 0.00 & 0.92 \\
\hline CAN & ON & Professional & Accountant & 0.47 & 0.99 & 0.00 & 1.46 & US & MA & Professional & Accountant & 0.00 & 0.00 & 0.00 & 0.00 \\
\hline CAN & ON & Professional & Architect & 0.47 & 1.23 & 0.47 & 2.16 & US & MA & Professional & Architect & 0.00 & 1.50 & 0.00 & 1.50 \\
\hline CAN & ON & Professional & Civil engineer & 0.47 & 1.17 & 0.00 & 1.63 & US & MA & Professional & Civil engineer & 0.00 & 1.42 & 0.00 & 1.42 \\
\hline
\end{tabular}


ECO/WKP(2020)14 | 55

\begin{tabular}{|c|c|c|c|c|c|c|c|c|c|c|c|c|c|c|c|}
\hline CAN & ON & Professional & Lawyer & 0.67 & 1.67 & 0.00 & 2.33 & US & MA & Professional & Lawyer & 0.00 & 1.25 & 0.00 & 1.25 \\
\hline CAN & ON & Professional & Real-estate agent & 0.67 & 0.83 & 0.67 & 2.17 & US & MA & Professional & Real-estate agent & 0.00 & 0.83 & 0.00 & 0.83 \\
\hline CAN & ON & Personal & Aesthetician & 0.00 & 0.00 & 0.00 & 0.00 & US & MA & Personal & Aesthetician & 0.00 & 0.83 & 0.00 & 0.83 \\
\hline CAN & ON & Personal & Baker & 0.00 & 0.00 & 0.00 & 0.00 & US & MA & Personal & Baker & 0.00 & 0.00 & 0.00 & 0.00 \\
\hline CAN & ON & Personal & Butcher & 0.00 & 0.00 & 0.00 & 0.00 & US & MA & Personal & Butcher & 0.00 & 0.00 & 0.00 & 0.00 \\
\hline CAN & ON & Personal & Driving instructor & 0.67 & 1.00 & 1.33 & 3.00 & US & MA & Personal & Driving instructor & 0.00 & 0.83 & 0.00 & 0.83 \\
\hline CAN & ON & Personal & Electrician & 0.67 & 1.33 & 0.00 & 2.00 & US & MA & Personal & Electrician & 0.00 & 1.08 & 0.00 & 1.08 \\
\hline CAN & ON & Personal & Hairdresser & 0.67 & 1.08 & 0.67 & 2.42 & US & MA & Personal & Hairdresser & 0.00 & 1.08 & 0.00 & 1.08 \\
\hline CAN & ON & Personal & Painter-decorator & 0.00 & 0.00 & 0.00 & 0.00 & US & MA & Personal & Painter-decorator & 0.00 & 0.00 & 0.00 & 0.00 \\
\hline CAN & ON & Personal & Plumber & 2.00 & 1.25 & 0.00 & 3.25 & US & MA & Personal & Plumber & 0.00 & 1.08 & 0.00 & 1.08 \\
\hline CAN & ON & Personal & Taxi driver & 1.33 & 0.58 & 0.67 & 2.58 & US & MA & Personal & Taxi driver & 0.67 & 0.50 & 0.67 & 1.83 \\
\hline CAN & ON & Nurse & Nurse & 0.67 & 1.17 & 0.67 & 2.50 & US & MA & Nurse & Nurse & 0.00 & 0.92 & 0.00 & 0.92 \\
\hline CAN & PEI & Professional & Accountant & 0.47 & 0.99 & 0.00 & 1.46 & US & MD & Professional & Accountant & 0.00 & 0.00 & 0.00 & 0.00 \\
\hline CAN & PEI & Professional & Architect & 0.47 & 1.17 & 0.00 & 1.63 & US & MD & Professional & Architect & 0.00 & 1.00 & 0.00 & 1.00 \\
\hline CAN & PEI & Professional & Civil engineer & 0.47 & 1.17 & 0.00 & 1.63 & US & MD & Professional & Civil engineer & 0.00 & 1.42 & 0.00 & 1.42 \\
\hline CAN & PEI & Professional & Lawyer & 0.67 & 1.08 & 0.00 & 1.75 & US & MD & Professional & Lawyer & 0.00 & 1.25 & 0.67 & 1.92 \\
\hline CAN & PEI & Professional & Real-estate agent & 0.67 & 1.33 & 2.00 & 4.00 & US & MD & Professional & Real-estate agent & 0.00 & 0.58 & 0.00 & 0.58 \\
\hline CAN & PEI & Personal & Aesthetician & 0.00 & 0.00 & 0.00 & 0.00 & US & MD & Personal & Aesthetician & 0.00 & 1.00 & 0.00 & 1.00 \\
\hline CAN & PEI & Personal & Baker & 0.00 & 0.00 & 0.00 & 0.00 & US & MD & Personal & Baker & 0.00 & 0.00 & 0.00 & 0.00 \\
\hline CAN & PEI & Personal & Butcher & 0.00 & 0.00 & 0.00 & 0.00 & US & MD & Personal & Butcher & 0.00 & 0.00 & 0.00 & 0.00 \\
\hline CAN & PEI & Personal & Driving instructor & 0.00 & 1.50 & 1.33 & 2.83 & US & MD & Personal & Driving instructor & 0.00 & 0.42 & 0.67 & 1.08 \\
\hline CAN & PEI & Personal & Electrician & 0.67 & 1.33 & 0.00 & 2.00 & US & MD & Personal & Electrician & 0.67 & 1.00 & 0.00 & 1.67 \\
\hline CAN & PEI & Personal & Hairdresser & 0.00 & 0.00 & 0.00 & 0.00 & US & MD & Personal & Hairdresser & 0.00 & 1.00 & 0.00 & 1.00 \\
\hline CAN & PEI & Personal & Painter-decorator & 0.00 & 0.00 & 0.00 & 0.00 & US & MD & Personal & Painter-decorator & 0.00 & 0.00 & 0.00 & 0.00 \\
\hline CAN & PEI & Personal & Plumber & 0.00 & 0.67 & 0.00 & 0.67 & US & MD & Personal & Plumber & 0.67 & 1.33 & 0.00 & 2.00 \\
\hline CAN & PEI & Personal & Taxi driver & 0.67 & 1.25 & 0.00 & 1.92 & US & MD & Personal & Taxi driver & 0.67 & 0.25 & 0.00 & 0.92 \\
\hline CAN & PEI & Nurse & Nurse & 0.67 & 1.67 & 0.00 & 2.33 & US & MD & Nurse & Nurse & 0.00 & 0.92 & 0.00 & 0.92 \\
\hline CAN & QC & Professional & Accountant & 0.67 & 1.67 & 0.00 & 2.33 & US & ME & Professional & Accountant & 0.00 & 0.00 & 0.00 & 0.00 \\
\hline CAN & QC & Professional & Architect & 0.67 & 1.67 & 0.00 & 2.33 & US & ME & Professional & Architect & 0.00 & 1.50 & 0.00 & 1.50 \\
\hline CAN & QC & Professional & Civil engineer & 0.47 & 0.93 & 0.47 & 1.87 & US & ME & Professional & Civil engineer & 0.00 & 1.42 & 0.00 & 1.42 \\
\hline CAN & $\mathrm{QC}$ & Professional & Lawyer & 0.67 & 1.17 & 0.00 & 1.83 & US & ME & Professional & Lawyer & 0.67 & 1.25 & 0.00 & 1.92 \\
\hline CAN & QC & Professional & Real-estate agent & 0.67 & 1.08 & 1.33 & 3.08 & US & ME & Professional & Real-estate agent & 0.00 & 0.83 & 0.67 & 1.50 \\
\hline CAN & QC & Personal & Aesthetician & 0.00 & 0.00 & 0.00 & 0.00 & US & ME & Personal & Aesthetician & 0.00 & 1.00 & 0.00 & 1.00 \\
\hline CAN & QC & Personal & Baker & 0.00 & 0.00 & 0.00 & 0.00 & US & ME & Personal & Baker & 0.00 & 0.00 & 0.00 & 0.00 \\
\hline CAN & QC & Personal & Butcher & 0.00 & 0.00 & 0.00 & 0.00 & US & ME & Personal & Butcher & 0.00 & 0.00 & 0.00 & 0.00 \\
\hline
\end{tabular}


56 | ECO/WKP(2020)14

\begin{tabular}{|c|c|c|c|c|c|c|c|c|c|c|c|c|c|c|c|}
\hline CAN & QC & Personal & Driving instructor & 0.00 & 0.00 & 0.00 & 0.00 & US & ME & Personal & Driving instructor & 0.00 & 1.33 & 0.00 & 1.33 \\
\hline CAN & $Q C$ & Personal & Electrician & 0.67 & 0.83 & 0.00 & 1.50 & US & ME & Personal & Electrician & 0.00 & 1.42 & 0.00 & 1.42 \\
\hline CAN & $Q C$ & Personal & Hairdresser & 0.00 & 0.00 & 0.00 & 0.00 & US & ME & Personal & Hairdresser & 0.00 & 1.00 & 0.00 & 1.00 \\
\hline CAN & QC & Personal & Painter-decorator & 0.00 & 1.33 & 0.00 & 1.33 & US & $\mathrm{ME}$ & Personal & Painter-decorator & 0.00 & 0.00 & 0.00 & 0.00 \\
\hline CAN & $Q C$ & Personal & Plumber & 0.67 & 1.33 & 0.00 & 2.00 & US & ME & Personal & Plumber & 0.00 & 1.25 & 0.00 & 1.25 \\
\hline CAN & $Q C$ & Personal & Taxi driver & 0.67 & 1.58 & 1.33 & 3.58 & US & ME & Personal & Taxi driver & 0.00 & 0.00 & 0.00 & 0.00 \\
\hline CAN & $Q C$ & Nurse & Nurse & 0.67 & 1.08 & 0.00 & 1.75 & US & ME & Nurse & Nurse & 0.00 & 0.92 & 0.00 & 0.92 \\
\hline CAN & SK & Professional & Accountant & 0.47 & 0.99 & 0.00 & 1.46 & US & $\mathrm{Ml}$ & Professional & Accountant & 0.00 & 0.00 & 0.00 & 0.00 \\
\hline CAN & SK & Professional & Architect & 0.47 & 0.70 & 0.00 & 1.17 & US & Ml & Professional & Architect & 0.00 & 1.50 & 0.00 & 1.50 \\
\hline CAN & SK & Professional & Civil engineer & 0.47 & 1.05 & 0.00 & 1.52 & US & $\mathrm{Ml}$ & Professional & Civil engineer & 0.00 & 1.75 & 0.00 & 1.75 \\
\hline CAN & SK & Professional & Lawyer & 0.67 & 1.58 & 0.00 & 2.25 & US & $\mathrm{Ml}$ & Professional & Lawyer & 0.67 & 1.00 & 0.00 & 1.67 \\
\hline CAN & SK & Professional & Real-estate agent & 0.67 & 0.83 & 0.67 & 2.17 & US & $\mathrm{Ml}$ & Professional & Real-estate agent & 0.00 & 1.08 & 0.00 & 1.08 \\
\hline CAN & SK & Personal & Aesthetician & 0.00 & 0.00 & 0.00 & 0.00 & US & $\mathrm{Ml}$ & Personal & Aesthetician & 0.00 & 1.25 & 0.00 & 1.25 \\
\hline CAN & SK & Personal & Baker & 0.00 & 0.00 & 0.00 & 0.00 & US & $\mathrm{Ml}$ & Personal & Baker & 0.00 & 0.00 & 0.00 & 0.00 \\
\hline CAN & SK & Personal & Butcher & 0.00 & 0.00 & 0.00 & 0.00 & US & $\mathrm{Ml}$ & Personal & Butcher & 0.00 & 0.00 & 0.00 & 0.00 \\
\hline CAN & SK & Personal & Driving instructor & 0.67 & 1.58 & 1.33 & 3.58 & US & $\mathrm{Ml}$ & Personal & Driving instructor & 0.00 & 0.58 & 0.67 & 1.25 \\
\hline CAN & SK & Personal & Electrician & 0.67 & 1.33 & 0.00 & 2.00 & US & $\mathrm{Ml}$ & Personal & Electrician & 0.67 & 1.25 & 0.00 & 1.92 \\
\hline CAN & SK & Personal & Hairdresser & 0.00 & 0.00 & 0.00 & 0.00 & US & $\mathrm{Ml}$ & Personal & Hairdresser & 0.00 & 1.25 & 0.00 & 1.25 \\
\hline CAN & SK & Personal & Painter-decorator & 0.00 & 0.67 & 0.00 & 0.67 & US & $\mathrm{Ml}$ & Personal & Painter-decorator & 0.00 & 0.00 & 0.00 & 0.00 \\
\hline CAN & SK & Personal & Plumber & 0.67 & 1.33 & 0.00 & 2.00 & US & $\mathrm{Ml}$ & Personal & Plumber & 0.67 & 1.58 & 0.00 & 2.25 \\
\hline CAN & SK & Personal & Taxi driver & 0.67 & 1.08 & 1.33 & 3.08 & US & $\mathrm{Ml}$ & Personal & Taxi driver & 0.00 & 1.00 & 0.67 & 1.67 \\
\hline CAN & SK & Nurse & Nurse & 0.67 & 1.17 & 0.00 & 1.83 & US & $\mathrm{Ml}$ & Nurse & Nurse & 0.00 & 1.17 & 0.00 & 1.17 \\
\hline $\mathrm{CHE}$ & $\mathrm{CHE}$ & Personal & Aesthetician & 0.00 & 0.00 & 0.00 & 0.00 & US & MN & Professional & Accountant & 0.00 & 0.00 & 0.00 & 0.00 \\
\hline Europe & AUT & Professional & Accountant & 0.67 & 1.75 & 0.67 & 3.08 & US & MN & Professional & Architect & 0.00 & 1.50 & 0.00 & 1.50 \\
\hline Europe & AUT & Professional & Architect & 0.67 & 1.25 & 0.67 & 2.58 & US & MN & Professional & Civil engineer & 0.00 & 1.50 & 0.00 & 1.50 \\
\hline Europe & AUT & Professional & Civil engineer & 0.67 & 1.67 & 0.67 & 3.00 & US & MN & Professional & Lawyer & 0.00 & 1.00 & 0.00 & 1.00 \\
\hline Europe & AUT & Professional & Lawyer & 0.67 & 1.33 & 0.67 & 2.67 & US & MN & Professional & Real-estate agent & 0.00 & 1.08 & 0.00 & 1.08 \\
\hline Europe & AUT & Professional & Real-estate agent & 0.47 & 0.53 & 0.47 & 1.46 & US & MN & Personal & Aesthetician & 0.00 & 1.08 & 0.67 & 1.75 \\
\hline Europe & AUT & Personal & Aesthetician & 0.47 & 0.76 & 0.47 & 1.69 & US & MN & Personal & Baker & 0.00 & 0.00 & 0.00 & 0.00 \\
\hline Europe & AUT & Personal & Baker & 0.47 & 0.82 & 0.47 & 1.75 & US & MN & Personal & Butcher & 0.00 & 0.00 & 0.00 & 0.00 \\
\hline Europe & AUT & Personal & Butcher & 0.47 & 0.82 & 0.47 & 1.75 & US & MN & Personal & Driving instructor & 0.00 & 1.08 & 0.67 & 1.75 \\
\hline Europe & AUT & Personal & Driving instructor & 0.67 & 1.25 & 0.00 & 1.92 & US & MN & Personal & Electrician & 0.00 & 1.25 & 0.00 & 1.25 \\
\hline Europe & AUT & Personal & Electrician & 0.47 & 0.82 & 0.47 & 1.75 & US & MN & Personal & Hairdresser & 0.00 & 1.08 & 0.67 & 1.75 \\
\hline Europe & AUT & Personal & Hairdresser & 0.47 & 0.82 & 0.47 & 1.75 & US & MN & Personal & Painter-decorator & 0.00 & 0.00 & 0.00 & 0.00 \\
\hline Europe & AUT & Personal & Painter-decorator & 0.47 & 0.82 & 0.47 & 1.75 & US & MN & Personal & Plumber & 0.67 & 1.25 & 0.00 & 1.92 \\
\hline
\end{tabular}


ECO/WKP(2020)14 | 57

\begin{tabular}{|c|c|c|c|c|c|c|c|c|c|c|c|c|c|c|c|}
\hline Europe & AUT & Personal & Plumber & 0.47 & 0.82 & 0.47 & 1.75 & US & MN & Personal & Taxi driver & 0.67 & 0.58 & 0.67 & 1.92 \\
\hline Europe & AUT & Personal & Taxi driver & 1.33 & 1.00 & 0.67 & 3.00 & US & MN & Nurse & Nurse & 0.00 & 1.17 & 0.00 & 1.17 \\
\hline Europe & AUT & Nurse & Nurse & 0.00 & 1.00 & 0.67 & 1.67 & US & MO & Professional & Accountant & 0.00 & 0.00 & 0.00 & 0.00 \\
\hline Europe & BEL & Professional & Accountant & 0.67 & 1.50 & 0.67 & 2.83 & US & MO & Professional & Architect & 0.00 & 1.50 & 0.00 & 1.50 \\
\hline Europe & BEL & Professional & Architect & 0.67 & 1.42 & 0.67 & 2.75 & US & MO & Professional & Civil engineer & 0.00 & 1.67 & 0.00 & 1.67 \\
\hline Europe & BEL & Professional & Civil Engineer & 0.00 & 0.00 & 0.00 & 0.00 & US & MO & Professional & Lawyer & 0.67 & 1.50 & 0.00 & 2.17 \\
\hline Europe & BEL & Professional & Lawyer & 0.67 & 1.92 & 0.67 & 3.25 & US & MO & Professional & Real-estate agent & 0.00 & 0.58 & 0.67 & 1.25 \\
\hline Europe & BEL & Professional & Real-estate agent & 0.67 & 1.75 & 0.00 & 2.42 & US & MO & Personal & Aesthetician & 0.00 & 1.00 & 0.67 & 1.67 \\
\hline Europe & BEL & Personal & Aesthetician & 0.00 & 0.12 & 0.00 & 0.12 & US & MO & Personal & Baker & 0.00 & 0.00 & 0.00 & 0.00 \\
\hline Europe & BEL & Personal & Baker & 0.00 & 0.12 & 0.00 & 0.12 & US & MO & Personal & Butcher & 0.00 & 0.00 & 0.00 & 0.00 \\
\hline Europe & BEL & Personal & Butcher & 0.00 & 0.42 & 0.00 & 0.42 & US & MO & Personal & Driving instructor & 0.00 & 1.42 & 0.00 & 1.42 \\
\hline Europe & BEL & Personal & Driving Instructor & 0.00 & 1.50 & 0.67 & 2.17 & US & $\mathrm{MO}$ & Personal & Electrician & 0.67 & 1.25 & 0.67 & 2.58 \\
\hline Europe & BEL & Personal & Electrician & 0.00 & 0.18 & 0.00 & 0.18 & US & $\mathrm{MO}$ & Personal & Hairdresser & 0.00 & 1.00 & 0.00 & 1.00 \\
\hline Europe & BEL & Personal & Hairdresser & 0.00 & 0.12 & 0.00 & 0.12 & US & MO & Personal & Painter-decorator & 0.00 & 0.00 & 0.00 & 0.00 \\
\hline Europe & BEL & Personal & Painter-decorator & 0.00 & 0.18 & 0.00 & 0.18 & US & $\mathrm{MO}$ & Personal & Plumber & 0.67 & 1.25 & 0.67 & 2.58 \\
\hline Europe & BEL & Personal & Plumber & 0.00 & 0.18 & 0.00 & 0.18 & US & MO & Personal & Taxi driver & 0.00 & 0.50 & 0.67 & 1.17 \\
\hline Europe & BEL & Personal & Taxi driver & 1.33 & 1.08 & 1.33 & 3.75 & US & MO & Nurse & Nurse & 0.00 & 0.92 & 0.00 & 0.92 \\
\hline Europe & BEL & Nurse & Nurse & 0.00 & 1.33 & 0.00 & 1.33 & US & MS & Professional & Accountant & 0.00 & 0.00 & 0.00 & 0.00 \\
\hline Europe & $\mathrm{CHE}$ & Professional & Accountant & 0.00 & 0.00 & 0.00 & 0.00 & US & MS & Professional & Architect & 0.00 & 1.50 & 0.00 & 1.50 \\
\hline Europe & $\mathrm{CHE}$ & Professional & Architect & 0.00 & 0.00 & 0.00 & 0.00 & US & MS & Professional & Civil engineer & 0.00 & 1.50 & 0.00 & 1.50 \\
\hline Europe & $\mathrm{CHE}$ & Professional & Civil engineer & 0.00 & 0.00 & 0.00 & 0.00 & US & MS & Professional & Lawyer & 0.67 & 1.25 & 0.00 & 1.92 \\
\hline Europe & CHE & Professional & Lawyer & 0.00 & 1.75 & 0.00 & 1.75 & US & MS & Professional & Real-estate agent & 0.00 & 0.83 & 0.00 & 0.83 \\
\hline Europe & $\mathrm{CHE}$ & Professional & Real-estate agent & 0.00 & 0.00 & 0.00 & 0.00 & US & MS & Personal & Aesthetician & 0.00 & 0.83 & 0.00 & 0.83 \\
\hline Europe & CHE & Personal & Baker & 0.00 & 0.00 & 0.00 & 0.00 & US & MS & Personal & Baker & 0.00 & 0.00 & 0.00 & 0.00 \\
\hline Europe & $\mathrm{CHE}$ & Personal & Butcher & 0.00 & 0.00 & 0.00 & 0.00 & US & MS & Personal & Butcher & 0.00 & 0.00 & 0.00 & 0.00 \\
\hline Europe & CHE & Personal & Driving instructor & 0.00 & 0.50 & 0.67 & 1.17 & US & MS & Personal & Driving instructor & 0.00 & 1.17 & 0.67 & 1.83 \\
\hline Europe & CHE & Personal & Electrician & 0.00 & 0.53 & 0.00 & 0.53 & US & MS & Personal & Electrician & 0.67 & 2.00 & 0.67 & 3.33 \\
\hline Europe & $\mathrm{CHE}$ & Personal & Hairdresser & 0.00 & 0.00 & 0.00 & 0.00 & US & MS & Personal & Hairdresser & 0.00 & 0.58 & 0.00 & 0.58 \\
\hline Europe & $\mathrm{CHE}$ & Personal & Painter-decorator & 0.00 & 0.00 & 0.00 & 0.00 & US & MS & Personal & Painter-decorator & 0.00 & 0.00 & 0.00 & 0.00 \\
\hline Europe & $\mathrm{CHE}$ & Personal & Plumber & 0.00 & 0.00 & 0.00 & 0.00 & US & MS & Personal & Plumber & 0.67 & 1.42 & 0.67 & 2.75 \\
\hline Europe & $\mathrm{CHE}$ & Personal & Taxi driver & 0.00 & 1.00 & 0.67 & 1.67 & US & MS & Personal & Taxi driver & 0.67 & 0.75 & 0.67 & 2.08 \\
\hline Europe & $\mathrm{CHE}$ & Nurse & Nurse & 0.00 & 0.13 & 0.00 & 0.13 & US & MS & Nurse & Nurse & 0.00 & 0.92 & 0.00 & 0.92 \\
\hline Europe & DEU & Professional & Accountant & 0.67 & 1.33 & 0.00 & 2.00 & US & MT & Professional & Accountant & 0.00 & 0.00 & 0.00 & 0.00 \\
\hline Europe & DEU & Professional & Architect & 0.67 & 1.11 & 0.00 & 1.78 & US & MT & Professional & Architect & 0.00 & 1.50 & 0.00 & 1.50 \\
\hline Europe & DEU & Professional & Civil Engineer & 0.00 & 0.75 & 0.00 & 0.75 & US & MT & Professional & Civil engineer & 0.00 & 1.42 & 0.00 & 1.42 \\
\hline
\end{tabular}


58 | ECO/WKP(2020)14

\begin{tabular}{|c|c|c|c|c|c|c|c|c|c|c|c|c|c|c|c|}
\hline Europe & DEU & Professional & Lawyer & 0.67 & 1.92 & 0.67 & 3.25 & US & MT & Professional & Lawyer & 0.67 & 1.50 & 0.00 & 2.17 \\
\hline Europe & DEU & Professional & Real-estate agent & 0.00 & 0.00 & 0.00 & 0.00 & US & MT & Professional & Real-estate agent & 0.00 & 0.83 & 0.67 & 1.50 \\
\hline Europe & DEU & Personal & Aesthetician & 0.00 & 0.00 & 0.00 & 0.00 & US & MT & Personal & Aesthetician & 0.00 & 0.83 & 0.00 & 0.83 \\
\hline Europe & DEU & Personal & Baker & 0.00 & 1.23 & 0.00 & 1.23 & US & MT & Personal & Baker & 0.00 & 0.00 & 0.00 & 0.00 \\
\hline Europe & DEU & Personal & Butcher & 0.00 & 1.23 & 0.00 & 1.23 & US & MT & Personal & Butcher & 0.00 & 0.00 & 0.00 & 0.00 \\
\hline Europe & DEU & Personal & Driving Instructor & 0.00 & 1.58 & 0.00 & 1.58 & US & MT & Personal & Driving instructor & 0.00 & 1.50 & 0.00 & 1.50 \\
\hline Europe & DEU & Personal & Electrician & 0.00 & 1.23 & 0.00 & 1.23 & US & MT & Personal & Electrician & 0.00 & 1.42 & 0.00 & 1.42 \\
\hline Europe & DEU & Personal & Hairdresser & 0.00 & 1.23 & 0.00 & 1.23 & US & MT & Personal & Hairdresser & 0.67 & 0.92 & 0.00 & 1.58 \\
\hline Europe & DEU & Personal & Painter-decorator & 0.00 & 1.23 & 0.00 & 1.23 & US & MT & Personal & Painter-decorator & 0.00 & 0.00 & 0.00 & 0.00 \\
\hline Europe & DEU & Personal & Plumber & 0.00 & 1.23 & 0.00 & 1.23 & US & MT & Personal & Plumber & 0.00 & 1.00 & 0.00 & 1.00 \\
\hline Europe & DEU & Personal & Taxi driver & 1.33 & 1.00 & 0.67 & 3.00 & US & MT & Personal & Taxi driver & 0.00 & 0.00 & 0.00 & 0.00 \\
\hline Europe & DEU & Nurse & Nurse & 0.00 & 0.63 & 0.00 & 0.63 & US & MT & Nurse & Nurse & 0.00 & 0.92 & 0.00 & 0.92 \\
\hline Europe & ESP & Professional & Accountant & 0.00 & 0.00 & 0.00 & 0.00 & US & NC & Professional & Accountant & 0.00 & 0.00 & 0.00 & 0.00 \\
\hline Europe & ESP & Professional & Architect & 0.67 & 0.92 & 0.00 & 1.58 & US & NC & Professional & Architect & 0.00 & 1.50 & 0.00 & 1.50 \\
\hline Europe & ESP & Professional & Civil Engineer & 0.67 & 0.83 & 0.00 & 1.50 & US & NC & Professional & Civil engineer & 0.00 & 1.50 & 0.00 & 1.50 \\
\hline Europe & ESP & Professional & Lawyer & 0.67 & 1.83 & 1.33 & 3.83 & US & NC & Professional & Lawyer & 0.00 & 1.50 & 0.00 & 1.50 \\
\hline Europe & ESP & Professional & Real-estate agent & 0.00 & 0.00 & 0.00 & 0.00 & US & NC & Professional & Real-estate agent & 0.00 & 1.00 & 0.00 & 1.00 \\
\hline Europe & ESP & Personal & Aesthetician & 0.00 & 0.00 & 0.00 & 0.00 & US & NC & Personal & Aesthetician & 0.00 & 0.83 & 0.00 & 0.83 \\
\hline Europe & ESP & Personal & Baker & 0.00 & 0.00 & 0.00 & 0.00 & US & NC & Personal & Baker & 0.00 & 0.00 & 0.00 & 0.00 \\
\hline Europe & ESP & Personal & Butcher & 0.00 & 0.00 & 0.00 & 0.00 & US & NC & Personal & Butcher & 0.00 & 0.00 & 0.00 & 0.00 \\
\hline Europe & ESP & Personal & Driving Instructor & 0.00 & 1.00 & 0.00 & 1.00 & US & NC & Personal & Driving instructor & 0.00 & 0.83 & 0.67 & 1.50 \\
\hline Europe & ESP & Personal & Electrician & 0.00 & 0.00 & 0.00 & 0.00 & US & NC & Personal & Electrician & 0.67 & 1.25 & 0.00 & 1.92 \\
\hline Europe & ESP & Personal & Hairdresser & 0.00 & 0.00 & 0.00 & 0.00 & US & NC & Personal & Hairdresser & 0.00 & 0.58 & 0.00 & 0.58 \\
\hline Europe & ESP & Personal & Painter-decorator & 0.00 & 0.00 & 0.00 & 0.00 & US & NC & Personal & Painter-decorator & 0.00 & 0.00 & 0.00 & 0.00 \\
\hline Europe & ESP & Personal & Plumber & 0.00 & 0.00 & 0.00 & 0.00 & US & NC & Personal & Plumber & 0.67 & 2.00 & 0.67 & 3.33 \\
\hline Europe & ESP & Personal & Taxi driver & 2.00 & 0.83 & 0.67 & 3.50 & US & NC & Personal & Taxi driver & 0.67 & 0.75 & 0.67 & 2.08 \\
\hline Europe & ESP & Nurse & Nurse & 0.67 & 0.83 & 0.00 & 1.50 & US & NC & Nurse & Nurse & 0.00 & 0.92 & 0.00 & 0.92 \\
\hline Europe & FIN & Professional & Accountant & 0.00 & 0.00 & 0.00 & 0.00 & US & ND & Professional & Accountant & 0.00 & 0.00 & 0.00 & 0.00 \\
\hline Europe & FIN & Professional & Architect & 0.00 & 0.00 & 0.00 & 0.00 & US & ND & Professional & Architect & 0.00 & 1.50 & 0.00 & 1.50 \\
\hline Europe & FIN & Professional & Civil Engineer & 0.00 & 0.00 & 0.00 & 0.00 & US & ND & Professional & Civil engineer & 0.00 & 1.00 & 0.00 & 1.00 \\
\hline Europe & FIN & Professional & Lawyer & 0.33 & 0.88 & 0.33 & 1.54 & US & ND & Professional & Lawyer & 0.67 & 1.50 & 0.00 & 2.17 \\
\hline Europe & FIN & Professional & Real-estate agent & 0.00 & 0.25 & 0.00 & 0.25 & US & ND & Professional & Real-estate agent & 0.00 & 1.08 & 0.00 & 1.08 \\
\hline Europe & FIN & Personal & Aesthetician & 0.00 & 0.00 & 0.00 & 0.00 & US & ND & Personal & Aesthetician & 0.00 & 1.08 & 0.00 & 1.08 \\
\hline Europe & FIN & Personal & Baker & 0.00 & 0.00 & 0.00 & 0.00 & US & ND & Personal & Baker & 0.00 & 0.00 & 0.00 & 0.00 \\
\hline Europe & FIN & Personal & Butcher & 0.00 & 0.00 & 0.00 & 0.00 & US & ND & Personal & Butcher & 0.00 & 0.00 & 0.00 & 0.00 \\
\hline
\end{tabular}


ECO/WKP(2020)14 | 59

\begin{tabular}{|c|c|c|c|c|c|c|c|c|c|c|c|c|c|c|c|}
\hline Europe & FIN & Personal & Driving Instructor & 0.00 & 0.67 & 0.00 & 0.67 & US & ND & Personal & Driving instructor & 0.00 & 1.08 & 0.00 & 1.08 \\
\hline Europe & FIN & Personal & Electrician & 0.00 & 1.05 & 0.00 & 1.05 & US & ND & Personal & Electrician & 0.00 & 1.00 & 0.00 & 1.00 \\
\hline Europe & FIN & Personal & Hairdresser & 0.00 & 0.00 & 0.00 & 0.00 & US & ND & Personal & Hairdresser & 0.00 & 1.17 & 0.67 & 1.83 \\
\hline Europe & FIN & Personal & Painter-decorator & 0.00 & 0.00 & 0.00 & 0.00 & US & ND & Personal & Painter-decorator & 0.00 & 0.00 & 0.00 & 0.00 \\
\hline Europe & FIN & Personal & Plumber & 0.00 & 0.00 & 0.00 & 0.00 & US & ND & Personal & Plumber & 0.00 & 1.25 & 0.00 & 1.25 \\
\hline Europe & FIN & Personal & Taxi driver & 0.67 & 1.08 & 0.67 & 2.42 & US & ND & Personal & Taxi driver & 0.00 & 1.00 & 0.67 & 1.67 \\
\hline Europe & FIN & Nurse & Nurse & 0.67 & 0.83 & 0.00 & 1.50 & US & ND & Nurse & Nurse & 0.00 & 0.92 & 0.00 & 0.92 \\
\hline Europe & FRA & Professional & Accountant & 0.67 & 1.67 & 1.33 & 3.67 & US & $\mathrm{NE}$ & Professional & Accountant & 0.00 & 0.00 & 0.00 & 0.00 \\
\hline Europe & FRA & Professional & Architect & 0.67 & 1.67 & 0.00 & 2.33 & US & $\mathrm{NE}$ & Professional & Architect & 0.00 & 1.50 & 0.67 & 2.17 \\
\hline Europe & FRA & Professional & Civil Engineer & 0.00 & 0.21 & 0.00 & 0.21 & US & $\mathrm{NE}$ & Professional & Civil engineer & 0.00 & 1.42 & 0.67 & 2.08 \\
\hline Europe & FRA & Professional & Lawyer & 1.33 & 1.67 & 0.67 & 3.67 & US & $\mathrm{NE}$ & Professional & Lawyer & 0.00 & 1.25 & 0.00 & 1.25 \\
\hline Europe & FRA & Professional & Real-estate agent & 0.00 & 0.25 & 0.00 & 0.25 & US & $\mathrm{NE}$ & Professional & Real-estate agent & 0.00 & 0.58 & 0.00 & 0.58 \\
\hline Europe & FRA & Personal & Aesthetician & 0.47 & 0.47 & 0.00 & 0.93 & US & $\mathrm{NE}$ & Personal & Aesthetician & 0.00 & 0.58 & 0.00 & 0.58 \\
\hline Europe & FRA & Personal & Baker & 0.00 & 0.82 & 0.00 & 0.82 & US & $\mathrm{NE}$ & Personal & Baker & 0.00 & 0.00 & 0.00 & 0.00 \\
\hline Europe & FRA & Personal & Butcher & 0.00 & 0.82 & 0.00 & 0.82 & US & $\mathrm{NE}$ & Personal & Butcher & 0.00 & 0.00 & 0.00 & 0.00 \\
\hline Europe & FRA & Personal & Driving Instructor & 0.00 & 1.00 & 0.00 & 1.00 & US & $\mathrm{NE}$ & Personal & Driving instructor & 0.00 & 1.42 & 0.00 & 1.42 \\
\hline Europe & FRA & Personal & Electrician & 0.47 & 0.47 & 0.00 & 0.93 & US & $\mathrm{NE}$ & Personal & Electrician & 0.00 & 1.00 & 0.00 & 1.00 \\
\hline Europe & FRA & Personal & Hairdresser & 0.00 & 0.53 & 0.00 & 0.53 & US & $\mathrm{NE}$ & Personal & Hairdresser & 0.00 & 0.67 & 0.00 & 0.67 \\
\hline Europe & FRA & Personal & Painter-decorator & 0.47 & 0.47 & 0.00 & 0.93 & US & $\mathrm{NE}$ & Personal & Painter-decorator & 0.00 & 0.00 & 0.00 & 0.00 \\
\hline Europe & FRA & Personal & Plumber & 0.47 & 0.47 & 0.00 & 0.93 & US & $\mathrm{NE}$ & Personal & Plumber & 0.67 & 2.00 & 0.67 & 3.33 \\
\hline Europe & FRA & Personal & Taxi driver & 1.33 & 1.08 & 0.67 & 3.08 & US & $\mathrm{NE}$ & Personal & Taxi driver & 0.00 & 0.50 & 0.67 & 1.17 \\
\hline Europe & FRA & Nurse & Nurse & 0.67 & 1.25 & 0.00 & 1.92 & US & $\mathrm{NE}$ & Nurse & Nurse & 0.00 & 0.92 & 0.00 & 0.92 \\
\hline Europe & GBR & Professional & Accountant & 1.33 & 1.25 & 0.00 & 2.58 & US & $\mathrm{NH}$ & Professional & Accountant & 0.00 & 0.00 & 0.00 & 0.00 \\
\hline Europe & GBR & Professional & Architect & 0.00 & 0.63 & 0.00 & 0.63 & US & $\mathrm{NH}$ & Professional & Architect & 0.00 & 1.50 & 0.00 & 1.50 \\
\hline Europe & GBR & Professional & Civil Engineer & 0.33 & 0.38 & 0.00 & 0.71 & US & $\mathrm{NH}$ & Professional & Civil engineer & 0.00 & 1.00 & 0.00 & 1.00 \\
\hline Europe & GBR & Professional & Lawyer & 1.33 & 0.75 & 0.67 & 2.75 & US & $\mathrm{NH}$ & Professional & Lawyer & 0.67 & 1.00 & 0.00 & 1.67 \\
\hline Europe & GBR & Professional & Real-estate agent & 0.00 & 0.00 & 0.00 & 0.00 & US & $\mathrm{NH}$ & Professional & Real-estate agent & 0.00 & 0.83 & 0.67 & 1.50 \\
\hline Europe & GBR & Personal & Aesthetician & 0.00 & 0.00 & 0.00 & 0.00 & US & $\mathrm{NH}$ & Personal & Aesthetician & 0.00 & 1.00 & 0.00 & 1.00 \\
\hline Europe & GBR & Personal & Baker & 0.00 & 0.00 & 0.00 & 0.00 & US & $\mathrm{NH}$ & Personal & Baker & 0.00 & 0.00 & 0.00 & 0.00 \\
\hline Europe & GBR & Personal & Butcher & 0.00 & 0.00 & 0.00 & 0.00 & US & $\mathrm{NH}$ & Personal & Butcher & 0.00 & 0.00 & 0.00 & 0.00 \\
\hline Europe & GBR & Personal & Driving Instructor & 1.33 & 0.50 & 0.67 & 2.50 & US & $\mathrm{NH}$ & Personal & Driving instructor & 0.00 & 0.83 & 0.67 & 1.50 \\
\hline Europe & GBR & Personal & Electrician & 0.00 & 0.00 & 0.00 & 0.00 & US & $\mathrm{NH}$ & Personal & Electrician & 0.00 & 1.25 & 0.00 & 1.25 \\
\hline Europe & GBR & Personal & Hairdresser & 0.00 & 0.00 & 0.00 & 0.00 & US & $\mathrm{NH}$ & Personal & Hairdresser & 0.00 & 0.50 & 0.00 & 0.50 \\
\hline Europe & GBR & Personal & Painter-decorator & 0.00 & 0.00 & 0.00 & 0.00 & US & $\mathrm{NH}$ & Personal & Painter-decorator & 0.00 & 0.00 & 0.00 & 0.00 \\
\hline Europe & GBR & Personal & Plumber & 0.00 & 0.00 & 0.00 & 0.00 & US & $\mathrm{NH}$ & Personal & Plumber & 0.00 & 1.67 & 0.00 & 1.67 \\
\hline
\end{tabular}


60 | ECO/WKP(2020)14

\begin{tabular}{|c|c|c|c|c|c|c|c|c|c|c|c|c|c|c|c|}
\hline Europe & GBR & Personal & Taxi driver & 0.00 & 1.00 & 0.67 & 1.67 & US & $\mathrm{NH}$ & Personal & Taxi driver & 0.00 & 0.50 & 0.67 & 1.17 \\
\hline Europe & GBR & Nurse & Nurse & 1.33 & 1.08 & 0.00 & 2.42 & US & $\mathrm{NH}$ & Nurse & Nurse & 0.00 & 0.92 & 0.00 & 0.92 \\
\hline Europe & HUN & Professional & Accountant & 0.00 & 1.25 & 0.00 & 1.25 & US & NJ & Professional & Accountant & 0.00 & 0.00 & 0.00 & 0.00 \\
\hline Europe & HUN & Professional & Architect & 0.67 & 1.83 & 0.67 & 3.17 & US & NJ & Professional & Architect & 0.00 & 1.50 & 0.00 & 1.50 \\
\hline Europe & HUN & Professional & Civil Engineer & 0.00 & 1.33 & 0.00 & 1.33 & US & NJ & Professional & Civil engineer & 0.00 & 1.42 & 0.00 & 1.42 \\
\hline Europe & HUN & Professional & Lawyer & 0.67 & 1.92 & 1.33 & 3.92 & US & NJ & Professional & Lawyer & 0.00 & 1.50 & 0.00 & 1.50 \\
\hline Europe & HUN & Professional & Real-estate agent & 0.00 & 1.08 & 0.00 & 1.08 & US & NJ & Professional & Real-estate agent & 0.00 & 0.83 & 0.67 & 1.50 \\
\hline Europe & HUN & Personal & Aesthetician & 0.00 & 0.33 & 0.00 & 0.33 & US & NJ & Personal & Aesthetician & 0.00 & 0.58 & 0.00 & 0.58 \\
\hline Europe & HUN & Personal & Baker & 0.00 & 0.00 & 0.00 & 0.00 & US & NJ & Personal & Baker & 0.00 & 0.00 & 0.00 & 0.00 \\
\hline Europe & HUN & Personal & Butcher & 0.00 & 0.00 & 0.00 & 0.00 & US & NJ & Personal & Butcher & 0.00 & 0.00 & 0.00 & 0.00 \\
\hline Europe & HUN & Personal & Driving Instructor & 0.00 & 1.08 & 0.67 & 1.75 & US & NJ & Personal & Driving instructor & 0.00 & 0.33 & 0.67 & 1.00 \\
\hline Europe & HUN & Personal & Electrician & 0.00 & 0.25 & 0.00 & 0.25 & US & NJ & Personal & Electrician & 0.00 & 1.25 & 0.67 & 1.92 \\
\hline Europe & HUN & Personal & Hairdresser & 0.00 & 0.33 & 0.00 & 0.33 & US & NJ & Personal & Hairdresser & 0.67 & 0.58 & 0.00 & 1.25 \\
\hline Europe & HUN & Personal & Painter-decorator & 0.00 & 0.50 & 0.00 & 0.50 & US & NJ & Personal & Painter-decorator & 0.00 & 0.00 & 0.00 & 0.00 \\
\hline Europe & HUN & Personal & Plumber & 0.00 & 0.25 & 0.00 & 0.25 & US & NJ & Personal & Plumber & 0.00 & 0.99 & 0.00 & 0.99 \\
\hline Europe & HUN & Personal & Taxi driver & 0.67 & 1.08 & 0.67 & 2.42 & US & NJ & Personal & Taxi driver & 1.33 & 0.50 & 0.67 & 2.50 \\
\hline Europe & HUN & Nurse & Nurse & 0.67 & 0.58 & 0.00 & 1.25 & US & NJ & Nurse & Nurse & 0.00 & 0.92 & 0.00 & 0.92 \\
\hline Europe & ISL & Professional & Accountant & 0.00 & 0.00 & 0.00 & 0.00 & US & NM & Professional & Accountant & 0.00 & 0.00 & 0.00 & 0.00 \\
\hline Europe & ISL & Professional & Architect & 0.00 & 1.50 & 0.00 & 1.50 & US & NM & Professional & Architect & 0.00 & 1.50 & 0.67 & 2.17 \\
\hline Europe & ISL & Professional & Civil Engineer & 0.00 & 1.92 & 0.00 & 1.92 & US & NM & Professional & Civil engineer & 0.00 & 1.42 & 0.00 & 1.42 \\
\hline Europe & ISL & Professional & Lawyer & 0.67 & 1.25 & 0.67 & 2.58 & US & NM & Professional & Lawyer & 0.67 & 1.50 & 0.00 & 2.17 \\
\hline Europe & ISL & Professional & Real-estate agent & 0.00 & 1.75 & 0.67 & 2.42 & US & NM & Professional & Real-estate agent & 0.00 & 1.08 & 0.00 & 1.08 \\
\hline Europe & ISL & Personal & Aesthetician & 0.00 & 1.23 & 0.00 & 1.23 & US & NM & Personal & Aesthetician & 0.00 & 1.00 & 0.67 & 1.67 \\
\hline Europe & ISL & Personal & Baker & 0.00 & 1.17 & 0.47 & 1.63 & US & NM & Personal & Baker & 0.00 & 0.00 & 0.00 & 0.00 \\
\hline Europe & ISL & Personal & Butcher & 0.00 & 1.11 & 0.00 & 1.11 & US & NM & Personal & Butcher & 0.00 & 0.00 & 0.00 & 0.00 \\
\hline Europe & ISL & Personal & Driving Instructor & 0.00 & 0.83 & 0.00 & 0.83 & US & NM & Personal & Driving instructor & 0.00 & 1.17 & 0.67 & 1.83 \\
\hline Europe & ISL & Personal & Electrician & 0.00 & 1.50 & 0.00 & 1.50 & US & NM & Personal & Electrician & 0.00 & 1.50 & 0.00 & 1.50 \\
\hline Europe & ISL & Personal & Hairdresser & 0.00 & 1.23 & 0.00 & 1.23 & US & NM & Personal & Hairdresser & 0.00 & 1.00 & 0.67 & 1.67 \\
\hline Europe & ISL & Personal & Painter-decorator & 0.00 & 1.33 & 0.00 & 1.33 & US & NM & Personal & Painter-decorator & 0.00 & 0.00 & 0.00 & 0.00 \\
\hline Europe & ISL & Personal & Plumber & 0.00 & 1.33 & 0.00 & 1.33 & US & NM & Personal & Plumber & 0.00 & 1.50 & 0.00 & 1.50 \\
\hline Europe & ISL & Personal & Taxi driver & 1.33 & 1.58 & 1.33 & 4.25 & US & NM & Personal & Taxi driver & 0.00 & 0.50 & 0.67 & 1.17 \\
\hline Europe & ISL & Nurse & Nurse & 0.00 & 1.83 & 0.00 & 1.83 & US & NM & Nurse & Nurse & 0.00 & 0.92 & 0.00 & 0.92 \\
\hline Europe & ITA & Professional & Accountant & 0.67 & 1.75 & 1.33 & 3.75 & US & NV & Professional & Accountant & 0.00 & 0.71 & 0.33 & 1.04 \\
\hline Europe & ITA & Professional & Architect & 0.67 & 1.42 & 0.67 & 2.75 & US & NV & Professional & Architect & 0.00 & 1.50 & 0.00 & 1.50 \\
\hline Europe & ITA & Professional & Civil Engineer & 0.67 & 1.42 & 1.33 & 3.42 & US & NV & Professional & Civil engineer & 0.00 & 1.67 & 0.67 & 2.33 \\
\hline
\end{tabular}


ECO/WKP(2020)14 | 61

\begin{tabular}{|c|c|c|c|c|c|c|c|c|c|c|c|c|c|c|c|}
\hline Europe & ITA & Professional & Lawyer & 0.67 & 1.92 & 0.00 & 2.58 & US & NV & Professional & Lawyer & 0.67 & 1.25 & 1.33 & 3.25 \\
\hline Europe & ITA & Professional & Real-estate agent & 0.00 & 0.83 & 0.00 & 0.83 & US & NV & Professional & Real-estate agent & 0.00 & 0.83 & 0.67 & 1.50 \\
\hline Europe & ITA & Personal & Aesthetician & 0.00 & 0.18 & 0.00 & 0.18 & US & NV & Personal & Aesthetician & 0.00 & 1.25 & 0.67 & 1.92 \\
\hline Europe & ITA & Personal & Baker & 0.00 & 0.00 & 0.00 & 0.00 & US & NV & Personal & Baker & 0.00 & 0.00 & 0.00 & 0.00 \\
\hline Europe & ITA & Personal & Butcher & 0.00 & 0.00 & 0.00 & 0.00 & US & NV & Personal & Butcher & 0.00 & 0.00 & 0.00 & 0.00 \\
\hline Europe & ITA & Personal & Driving Instructor & 0.00 & 1.00 & 0.00 & 1.00 & US & NV & Personal & Driving instructor & 0.00 & 1.08 & 0.67 & 1.75 \\
\hline Europe & ITA & Personal & Electrician & 0.00 & 0.42 & 0.00 & 0.42 & US & NV & Personal & Electrician & 0.67 & 1.25 & 0.00 & 1.92 \\
\hline Europe & ITA & Personal & Hairdresser & 0.00 & 0.70 & 0.00 & 0.70 & US & NV & Personal & Hairdresser & 0.00 & 1.25 & 0.67 & 1.92 \\
\hline Europe & ITA & Personal & Painter-decorator & 0.00 & 0.00 & 0.00 & 0.00 & US & NV & Personal & Painter-decorator & 0.00 & 0.00 & 0.00 & 0.00 \\
\hline Europe & ITA & Personal & Plumber & 0.00 & 0.00 & 0.00 & 0.00 & US & NV & Personal & Plumber & 0.67 & 1.42 & 0.67 & 2.75 \\
\hline Europe & ITA & Personal & Taxi driver & 2.00 & 0.75 & 0.67 & 3.42 & US & NV & Personal & Taxi driver & 0.00 & 0.50 & 0.67 & 1.17 \\
\hline Europe & ITA & Nurse & Nurse & 0.67 & 0.75 & 0.00 & 1.42 & US & NV & Nurse & Nurse & 0.00 & 1.17 & 0.00 & 1.17 \\
\hline Europe & $\mathrm{POL}$ & Professional & Accountant & 0.00 & 0.00 & 0.00 & 0.00 & US & NY & Professional & Accountant & 0.00 & 0.00 & 0.00 & 0.00 \\
\hline Europe & POL & Professional & Architect & 0.67 & 1.83 & 0.00 & 2.50 & US & NY & Professional & Architect & 0.00 & 1.50 & 0.00 & 1.50 \\
\hline Europe & $\mathrm{POL}$ & Professional & Civil engineer & 0.67 & 1.83 & 0.00 & 2.50 & US & NY & Professional & Civil engineer & 0.00 & 1.42 & 0.00 & 1.42 \\
\hline Europe & $\mathrm{POL}$ & Professional & Lawyer & 0.67 & 1.42 & 0.00 & 2.08 & US & NY & Professional & Lawyer & 0.47 & 0.99 & 0.00 & 1.46 \\
\hline Europe & POL & Professional & Real-estate agent & 0.00 & 0.00 & 0.00 & 0.00 & US & NY & Professional & Real-estate agent & 0.00 & 0.83 & 0.00 & 0.83 \\
\hline Europe & $\mathrm{POL}$ & Personal & Aesthetician & 0.00 & 0.54 & 0.00 & 0.54 & US & NY & Personal & Aesthetician & 0.00 & 0.83 & 0.00 & 0.83 \\
\hline Europe & POL & Personal & Baker & 0.00 & 0.54 & 0.00 & 0.54 & US & NY & Personal & Baker & 0.00 & 0.00 & 0.00 & 0.00 \\
\hline Europe & $\mathrm{POL}$ & Personal & Butcher & 0.00 & 0.54 & 0.00 & 0.54 & US & NY & Personal & Butcher & 0.00 & 0.00 & 0.00 & 0.00 \\
\hline Europe & $\mathrm{POL}$ & Personal & Driving instructor & 0.00 & 1.08 & 0.00 & 1.08 & US & NY & Personal & Driving instructor & 0.00 & 0.83 & 0.67 & 1.50 \\
\hline Europe & $\mathrm{POL}$ & Personal & Electrician & 0.00 & 1.08 & 0.00 & 1.08 & US & NY & Personal & Electrician & 0.00 & 1.00 & 0.00 & 1.00 \\
\hline Europe & POL & Personal & Hairdresser & 0.00 & 0.54 & 0.00 & 0.54 & US & NY & Personal & Hairdresser & 0.00 & 0.83 & 0.00 & 0.83 \\
\hline Europe & POL & Personal & Painter-decorator & 0.00 & 0.54 & 0.00 & 0.54 & US & NY & Personal & Painter-decorator & 0.00 & 0.00 & 0.00 & 0.00 \\
\hline Europe & POL & Personal & Plumber & 0.00 & 1.08 & 0.00 & 1.08 & US & NY & Personal & Plumber & 0.67 & 2.00 & 0.67 & 3.33 \\
\hline Europe & $\mathrm{POL}$ & Personal & Taxi driver & 0.67 & 1.33 & 0.67 & 2.67 & US & NY & Personal & Taxi driver & 0.00 & 0.08 & 0.67 & 0.75 \\
\hline Europe & $\mathrm{POL}$ & Nurse & Nurse & 1.33 & 0.75 & 0.00 & 2.08 & US & NY & Nurse & Nurse & 0.00 & 1.17 & 0.00 & 1.17 \\
\hline Europe & PRT & Professional & Accountant & 0.67 & 1.75 & 0.67 & 3.08 & US & $\mathrm{OH}$ & Professional & Accountant & 0.00 & 0.75 & 0.00 & 0.75 \\
\hline Europe & PRT & Professional & Architect & 0.67 & 1.42 & 0.00 & 2.08 & US & $\mathrm{OH}$ & Professional & Architect & 0.00 & 1.50 & 0.00 & 1.50 \\
\hline Europe & PRT & Professional & Civil Engineer & 0.00 & 1.17 & 0.67 & 1.83 & US & $\mathrm{OH}$ & Professional & Civil engineer & 0.00 & 1.42 & 0.00 & 1.42 \\
\hline Europe & PRT & Professional & Lawyer & 0.67 & 2.00 & 0.67 & 3.33 & US & $\mathrm{OH}$ & Professional & Lawyer & 0.00 & 1.25 & 0.00 & 1.25 \\
\hline Europe & PRT & Professional & Real-estate agent & 0.00 & 0.00 & 0.00 & 0.00 & US & $\mathrm{OH}$ & Professional & Real-estate agent & 0.00 & 0.58 & 0.67 & 1.25 \\
\hline Europe & PRT & Personal & Aesthetician & 0.00 & 0.00 & 0.00 & 0.00 & US & $\mathrm{OH}$ & Personal & Aesthetician & 0.00 & 0.83 & 0.00 & 0.83 \\
\hline Europe & PRT & Personal & Baker & 0.00 & 0.00 & 0.00 & 0.00 & US & $\mathrm{OH}$ & Personal & Baker & 0.00 & 0.00 & 0.00 & 0.00 \\
\hline Europe & PRT & Personal & Butcher & 0.00 & 0.00 & 0.00 & 0.00 & US & $\mathrm{OH}$ & Personal & Butcher & 0.00 & 0.00 & 0.00 & 0.00 \\
\hline
\end{tabular}


62 | ECO/WKP(2020)14

\begin{tabular}{|c|c|c|c|c|c|c|c|c|c|c|c|c|c|c|c|}
\hline Europe & PRT & Personal & Driving Instructor & 0.00 & 1.50 & 0.00 & 1.50 & US & $\mathrm{OH}$ & Personal & Driving instructor & 0.00 & 0.58 & 0.67 & 1.25 \\
\hline Europe & PRT & Personal & Electrician & 0.67 & 1.75 & 0.00 & 2.42 & US & $\mathrm{OH}$ & Personal & Electrician & 0.67 & 1.25 & 0.00 & 1.92 \\
\hline Europe & PRT & Personal & Hairdresser & 0.00 & 0.00 & 0.00 & 0.00 & US & $\mathrm{OH}$ & Personal & Hairdresser & 0.67 & 0.58 & 0.00 & 1.25 \\
\hline Europe & PRT & Personal & Painter-decorator & 0.00 & 0.00 & 0.00 & 0.00 & US & $\mathrm{OH}$ & Personal & Painter-decorator & 0.00 & 0.00 & 0.00 & 0.00 \\
\hline Europe & PRT & Personal & Plumber & 0.00 & 0.00 & 0.00 & 0.00 & US & $\mathrm{OH}$ & Personal & Plumber & 0.67 & 1.00 & 0.00 & 1.67 \\
\hline Europe & PRT & Personal & Taxi driver & 1.33 & 1.08 & 0.67 & 3.08 & US & $\mathrm{OH}$ & Personal & Taxi driver & 0.67 & 0.50 & 0.67 & 1.83 \\
\hline Europe & PRT & Nurse & Nurse & 0.67 & 0.50 & 0.00 & 1.17 & US & $\mathrm{OH}$ & Nurse & Nurse & 0.00 & 0.92 & 0.00 & 0.92 \\
\hline Europe & SVN & Professional & Accountant & 0.00 & 0.00 & 0.00 & 0.00 & US & $\mathrm{OK}$ & Professional & Accountant & 0.00 & 0.83 & 0.00 & 0.83 \\
\hline Europe & SVN & Professional & Architect & 0.67 & 1.92 & 0.00 & 2.58 & US & OK & Professional & Architect & 0.00 & 1.50 & 0.67 & 2.17 \\
\hline Europe & SVN & Professional & Civil Engineer & 0.67 & 1.42 & 0.00 & 2.08 & US & OK & Professional & Civil engineer & 0.00 & 1.42 & 0.00 & 1.42 \\
\hline Europe & SVN & Professional & Lawyer & 0.67 & 1.92 & 1.33 & 3.92 & US & OK & Professional & Lawyer & 0.67 & 1.50 & 0.00 & 2.17 \\
\hline Europe & SVN & Professional & Real-estate agent & 0.00 & 0.92 & 0.67 & 1.58 & US & OK & Professional & Real-estate agent & 0.00 & 0.58 & 0.67 & 1.25 \\
\hline Europe & SVN & Personal & Aesthetician & 0.00 & 0.58 & 0.00 & 0.58 & US & OK & Personal & Aesthetician & 0.00 & 1.00 & 0.67 & 1.67 \\
\hline Europe & SVN & Personal & Baker & 0.00 & 0.23 & 0.00 & 0.23 & US & OK & Personal & Baker & 0.00 & 0.00 & 0.00 & 0.00 \\
\hline Europe & SVN & Personal & Butcher & 0.00 & 0.00 & 0.00 & 0.00 & US & OK & Personal & Butcher & 0.00 & 0.00 & 0.00 & 0.00 \\
\hline Europe & SVN & Personal & Driving Instructor & 0.00 & 1.08 & 0.00 & 1.08 & US & OK & Personal & Driving instructor & 0.00 & 0.25 & 0.67 & 0.92 \\
\hline Europe & SVN & Personal & Electrician & 0.00 & 0.41 & 0.00 & 0.41 & US & OK & Personal & Electrician & 1.33 & 1.25 & 0.67 & 3.25 \\
\hline Europe & SVN & Personal & Hairdresser & 0.00 & 0.35 & 0.00 & 0.35 & US & OK & Personal & Hairdresser & 0.00 & 1.00 & 0.67 & 1.67 \\
\hline Europe & SVN & Personal & Painter-decorator & 0.00 & 0.00 & 0.00 & 0.00 & US & OK & Personal & Painter-decorator & 0.00 & 0.00 & 0.00 & 0.00 \\
\hline Europe & SVN & Personal & Plumber & 0.00 & 0.41 & 0.00 & 0.41 & US & OK & Personal & Plumber & 0.00 & 1.00 & 0.00 & 1.00 \\
\hline Europe & SVN & Personal & Taxi driver & 1.00 & 0.75 & 0.67 & 2.42 & US & OK & Personal & Taxi driver & 0.67 & 0.50 & 0.67 & 1.83 \\
\hline Europe & SVN & Nurse & Nurse & 0.67 & 0.75 & 0.00 & 1.42 & US & OK & Nurse & Nurse & 0.00 & 0.92 & 0.00 & 0.92 \\
\hline Europe & SWE & Professional & Accountant & 0.00 & 0.00 & 0.00 & 0.00 & US & OR & Professional & Accountant & 0.00 & 0.00 & 0.00 & 0.00 \\
\hline Europe & SWE & Professional & Architect & 0.00 & 0.00 & 0.00 & 0.00 & US & OR & Professional & Architect & 0.00 & 1.50 & 0.67 & 2.17 \\
\hline Europe & SWE & Professional & Civil Engineer & 0.00 & 0.00 & 0.00 & 0.00 & US & OR & Professional & Civil engineer & 0.00 & 1.42 & 0.00 & 1.42 \\
\hline Europe & SWE & Professional & Lawyer & 0.33 & 0.75 & 0.00 & 1.08 & US & OR & Professional & Lawyer & 0.67 & 1.25 & 0.00 & 1.92 \\
\hline Europe & SWE & Professional & Real-estate agent & 0.67 & 1.17 & 0.00 & 1.83 & US & OR & Professional & Real-estate agent & 0.00 & 1.08 & 0.00 & 1.08 \\
\hline Europe & SWE & Personal & Aesthetician & 0.00 & 0.00 & 0.00 & 0.00 & US & OR & Personal & Aesthetician & 0.00 & 0.83 & 0.67 & 1.50 \\
\hline Europe & SWE & Personal & Baker & 0.00 & 0.00 & 0.00 & 0.00 & US & OR & Personal & Baker & 0.00 & 0.00 & 0.00 & 0.00 \\
\hline Europe & SWE & Personal & Butcher & 0.00 & 0.00 & 0.00 & 0.00 & US & OR & Personal & Butcher & 0.00 & 0.00 & 0.00 & 0.00 \\
\hline Europe & SWE & Personal & Driving Instructor & 0.00 & 0.67 & 0.00 & 0.67 & US & OR & Personal & Driving instructor & 0.00 & 0.33 & 0.67 & 1.00 \\
\hline Europe & SWE & Personal & Electrician & 0.00 & 0.00 & 0.00 & 0.00 & US & OR & Personal & Electrician & 0.00 & 1.42 & 0.00 & 1.42 \\
\hline Europe & SWE & Personal & Hairdresser & 0.00 & 0.00 & 0.00 & 0.00 & US & OR & Personal & Hairdresser & 0.00 & 0.92 & 0.67 & 1.58 \\
\hline Europe & SWE & Personal & ainter-decorator & 0.00 & 0.00 & 0.00 & 0.00 & US & OR & Personal & Painter-decorator & 0.00 & 0.00 & 0.00 & 0.00 \\
\hline Europe & SWE & Personal & Plumber & 0.00 & 0.00 & 0.00 & 0.00 & US & OR & Personal & Plumber & 0.00 & 0.92 & 0.00 & 0.92 \\
\hline
\end{tabular}


ECO/WKP(2020)14 | 63

\begin{tabular}{|c|c|c|c|c|c|c|c|c|c|c|c|c|c|c|c|}
\hline Europe & SWE & Personal & Taxi driver & 0.00 & 1.00 & 0.67 & 1.67 & US & OR & Personal & Taxi driver & 0.00 & 0.00 & 0.00 & 0.00 \\
\hline Europe & SWE & Nurse & Nurse & 0.00 & 0.75 & 0.00 & 0.75 & US & OR & Nurse & Nurse & 0.00 & 0.92 & 0.00 & 0.92 \\
\hline IND & IND & Professional & Accountant & 0.67 & 1.58 & 0.67 & 2.92 & US & PA & Professional & Accountant & 0.00 & 0.00 & 0.00 & 0.00 \\
\hline IND & IND & Professional & Architect & 0.67 & 2.00 & 1.33 & 4.00 & US & PA & Professional & Architect & 0.00 & 1.50 & 0.00 & 1.50 \\
\hline IND & IND & Professional & Civil Engineer & 0.00 & 0.00 & 0.00 & 0.00 & US & PA & Professional & Civil engineer & 0.00 & 1.42 & 0.00 & 1.42 \\
\hline IND & IND & Professional & Lawyer & 1.33 & 1.42 & 0.67 & 3.42 & US & PA & Professional & Lawyer & 0.00 & 1.25 & 0.00 & 1.25 \\
\hline IND & IND & Professional & Real-estate agent & 1.33 & 0.00 & 0.67 & 2.00 & US & PA & Professional & Real-estate agent & 0.00 & 1.08 & 0.00 & 1.08 \\
\hline IND & IND & Personal & Aesthetician & 0.00 & 0.00 & 0.00 & 0.00 & US & $\mathrm{PA}$ & Personal & Aesthetician & 0.00 & 1.08 & 0.00 & 1.08 \\
\hline IND & IND & Personal & Baker & 0.00 & 0.00 & 0.00 & 0.00 & US & PA & Personal & Baker & 0.00 & 0.00 & 0.00 & 0.00 \\
\hline IND & IND & Personal & Butcher & 0.00 & 0.00 & 0.00 & 0.00 & US & $\mathrm{PA}$ & Personal & Butcher & 0.00 & 0.00 & 0.00 & 0.00 \\
\hline IND & IND & Personal & Driving Instructor & 0.00 & 1.17 & 0.67 & 1.83 & US & PA & Personal & Driving instructor & 0.00 & 0.75 & 0.67 & 1.42 \\
\hline IND & IND & Personal & Electrician & 0.67 & 0.17 & 0.67 & 1.50 & US & PA & Personal & Electrician & 0.67 & 2.00 & 0.67 & 3.33 \\
\hline IND & IND & Personal & Hairdresser & 0.00 & 0.00 & 0.00 & 0.00 & US & PA & Personal & Hairdresser & 0.00 & 1.00 & 0.00 & 1.00 \\
\hline IND & IND & Personal & Painter-decorator & 0.00 & 0.00 & 0.00 & 0.00 & US & PA & Personal & Painter-decorator & 0.00 & 0.00 & 0.00 & 0.00 \\
\hline IND & IND & Personal & Plumber & 0.00 & 0.00 & 0.00 & 0.00 & US & PA & Personal & Plumber & 0.00 & 2.00 & 0.67 & 2.67 \\
\hline IND & IND & Personal & Taxi driver & 0.00 & 1.00 & 0.67 & 1.67 & US & PA & Personal & Taxi driver & 0.67 & 1.08 & 0.67 & 2.42 \\
\hline IND & IND & Nurse & Nurse & 1.33 & 0.25 & 1.33 & 2.92 & US & PA & Nurse & Nurse & 0.00 & 0.92 & 0.00 & 0.92 \\
\hline ISR & ISR & Professional & Accountant & 0.00 & 0.00 & 0.00 & 0.00 & US & $\mathrm{RI}$ & Professional & Accountant & 0.00 & 0.75 & 0.00 & 0.75 \\
\hline ISR & ISR & Professional & Architect & 0.00 & 0.50 & 0.67 & 1.17 & US & RI & Professional & Architect & 0.00 & 1.50 & 0.00 & 1.50 \\
\hline ISR & ISR & Professional & Civil Engineer & 0.00 & 0.50 & 0.67 & 1.17 & US & RI & Professional & Civil engineer & 0.00 & 1.42 & 0.00 & 1.42 \\
\hline ISR & ISR & Professional & Lawyer & 0.67 & 1.83 & 0.67 & 3.17 & US & $\mathrm{RI}$ & Professional & Lawyer & 0.67 & 1.50 & 0.67 & 2.83 \\
\hline ISR & ISR & Professional & Real-estate agent & 0.00 & 1.00 & 1.33 & 2.33 & US & $\mathrm{RI}$ & Professional & Real-estate agent & 0.00 & 0.58 & 0.00 & 0.58 \\
\hline ISR & ISR & Personal & Aesthetician & 0.00 & 0.00 & 0.00 & 0.00 & US & RI & Personal & Aesthetician & 0.00 & 0.58 & 0.67 & 1.25 \\
\hline ISR & ISR & Personal & Baker & 0.00 & 0.00 & 0.00 & 0.00 & US & RI & Personal & Baker & 0.00 & 0.00 & 0.00 & 0.00 \\
\hline ISR & ISR & Personal & Butcher & 0.00 & 0.00 & 0.00 & 0.00 & US & RI & Personal & Butcher & 0.00 & 0.00 & 0.00 & 0.00 \\
\hline ISR & ISR & Personal & Driving Instructor & 0.00 & 1.58 & 0.67 & 2.25 & US & $\mathrm{RI}$ & Personal & Driving instructor & 0.00 & 1.92 & 0.00 & 1.92 \\
\hline ISR & ISR & Personal & Electrician & 0.00 & 0.17 & 0.67 & 0.83 & US & RI & Personal & Electrician & 0.00 & 1.33 & 0.00 & 1.33 \\
\hline ISR & ISR & Personal & Hairdresser & 0.00 & 0.00 & 0.00 & 0.00 & US & RI & Personal & Hairdresser & 0.00 & 0.83 & 0.67 & 1.50 \\
\hline ISR & ISR & Personal & Painter-decorator & 0.00 & 0.00 & 0.00 & 0.00 & US & $\mathrm{RI}$ & Personal & Painter-decorator & 0.00 & 0.00 & 0.00 & 0.00 \\
\hline ISR & ISR & Personal & Plumber & 0.00 & 0.00 & 0.00 & 0.00 & US & RI & Personal & Plumber & 0.00 & 1.08 & 0.00 & 1.08 \\
\hline ISR & ISR & Personal & Taxi driver & 0.00 & 1.58 & 0.67 & 2.25 & US & RI & Personal & Taxi driver & 0.00 & 0.50 & 0.00 & 0.50 \\
\hline ISR & ISR & Nurse & Nurse & 0.00 & 1.00 & 0.67 & 1.67 & US & RI & Nurse & Nurse & 0.00 & 0.92 & 0.00 & 0.92 \\
\hline US & AK & Professional & Accountant & 0.00 & 0.00 & 0.00 & 0.00 & US & SC & Professional & Accountant & 0.00 & 0.00 & 0.00 & 0.00 \\
\hline US & AK & Professional & Architect & 0.00 & 1.50 & 0.00 & 1.50 & US & SC & Professional & Architect & 0.00 & 1.50 & 0.00 & 1.50 \\
\hline US & AK & Professional & Civil engineer & 0.00 & 1.33 & 0.00 & 1.33 & US & SC & Professional & Civil engineer & 0.00 & 1.50 & 0.00 & 1.50 \\
\hline
\end{tabular}


$64 \mid \operatorname{ECO} / \mathrm{WKP}(2020) 14$

\begin{tabular}{|c|c|c|c|c|c|c|c|c|c|c|c|c|c|c|c|}
\hline US & AK & Professional & Lawyer & 0.67 & 1.00 & 0.00 & 1.67 & US & SC & Professional & Lawyer & 0.67 & 1.25 & 0.00 & 1.92 \\
\hline US & AK & Professional & Real-estate agent & 0.00 & 0.83 & 0.67 & 1.50 & US & SC & Professional & Real-estate agent & 0.00 & 1.00 & 0.67 & 1.67 \\
\hline US & AK & Personal & Aesthetician & 0.00 & 0.58 & 0.00 & 0.58 & US & SC & Personal & Aesthetician & 0.00 & 0.83 & 0.00 & 0.83 \\
\hline US & AK & Personal & Baker & 0.00 & 0.00 & 0.00 & 0.00 & US & SC & Personal & Baker & 0.00 & 0.00 & 0.00 & 0.00 \\
\hline US & AK & Personal & Butcher & 0.00 & 0.00 & 0.00 & 0.00 & US & SC & Personal & Butcher & 0.00 & 0.00 & 0.00 & 0.00 \\
\hline US & AK & Personal & Driving instructor & 0.00 & 1.33 & 0.67 & 2.00 & US & SC & Personal & Driving instructor & 0.00 & 0.75 & 0.67 & 1.42 \\
\hline US & AK & Personal & Electrician & 0.00 & 1.00 & 0.00 & 1.00 & US & SC & Personal & Electrician & 0.47 & 1.05 & 0.00 & 1.52 \\
\hline US & AK & Personal & Hairdresser & 0.00 & 1.00 & 0.00 & 1.00 & US & SC & Personal & Hairdresser & 0.00 & 1.00 & 0.00 & 1.00 \\
\hline US & AK & Personal & Painter-decorator & 0.00 & 0.00 & 0.00 & 0.00 & US & SC & Personal & Painter-decorator & 0.00 & 0.00 & 0.00 & 0.00 \\
\hline US & AK & Personal & Plumber & 0.00 & 1.00 & 0.00 & 1.00 & US & SC & Personal & Plumber & 0.67 & 2.00 & 0.67 & 3.33 \\
\hline US & AK & Personal & Taxi driver & 0.00 & 0.25 & 0.67 & 0.92 & US & SC & Personal & Taxi driver & 0.67 & 0.50 & 0.67 & 1.83 \\
\hline US & AK & Nurse & Nurse & 0.00 & 0.92 & 0.00 & 0.92 & US & SC & Nurse & Nurse & 0.00 & 1.17 & 0.00 & 1.17 \\
\hline US & $\mathrm{AL}$ & Professional & Accountant & 0.00 & 0.00 & 0.00 & 0.00 & US & SD & Professional & Accountant & 0.00 & 0.00 & 0.00 & 0.00 \\
\hline US & $\mathrm{AL}$ & Professional & Architect & 0.00 & 1.50 & 0.00 & 1.50 & US & SD & Professional & Architect & 0.00 & 1.50 & 0.67 & 2.17 \\
\hline US & $\mathrm{AL}$ & Professional & Civil engineer & 0.00 & 1.67 & 0.00 & 1.67 & US & SD & Professional & Civil engineer & 0.00 & 1.50 & 0.00 & 1.50 \\
\hline US & $\mathrm{AL}$ & Professional & Lawyer & 0.67 & 1.00 & 0.00 & 1.67 & US & SD & Professional & Lawyer & 0.67 & 1.25 & 0.00 & 1.92 \\
\hline US & $\mathrm{AL}$ & Professional & Real-estate agent & 0.00 & 0.83 & 0.67 & 1.50 & US & SD & Professional & Real-estate agent & 0.00 & 0.58 & 0.67 & 1.25 \\
\hline US & $\mathrm{AL}$ & Personal & Aesthetician & 0.00 & 1.00 & 0.00 & 1.00 & US & SD & Personal & Aesthetician & 0.00 & 0.83 & 0.67 & 1.50 \\
\hline US & $\mathrm{AL}$ & Personal & Baker & 0.00 & 0.00 & 0.00 & 0.00 & US & SD & Personal & Baker & 0.00 & 0.00 & 0.00 & 0.00 \\
\hline US & $\mathrm{AL}$ & Personal & Butcher & 0.00 & 0.00 & 0.00 & 0.00 & US & SD & Personal & Butcher & 0.00 & 0.00 & 0.00 & 0.00 \\
\hline US & $\mathrm{AL}$ & Personal & Driving instructor & 0.00 & 1.42 & 0.00 & 1.42 & US & SD & Personal & Driving instructor & 0.00 & 0.25 & 0.67 & 0.92 \\
\hline US & $\mathrm{AL}$ & Personal & Electrician & 0.00 & 1.25 & 0.00 & 1.25 & US & SD & Personal & Electrician & 0.00 & 1.25 & 0.00 & 1.25 \\
\hline US & $\mathrm{AL}$ & Personal & Hairdresser & 0.00 & 1.00 & 0.00 & 1.00 & US & SD & Personal & Hairdresser & 0.00 & 1.00 & 0.67 & 1.67 \\
\hline US & $\mathrm{AL}$ & Personal & Painter-decorator & 0.00 & 0.00 & 0.00 & 0.00 & US & SD & Personal & Painter-decorator & 0.00 & 0.00 & 0.00 & 0.00 \\
\hline US & $\mathrm{AL}$ & Personal & Plumber & 0.00 & 1.00 & 0.00 & 1.00 & US & SD & Personal & Plumber & 0.00 & 1.33 & 0.00 & 1.33 \\
\hline US & $\mathrm{AL}$ & Personal & Taxi driver & 0.00 & 0.50 & 0.67 & 1.17 & US & SD & Personal & Taxi driver & 0.67 & 2.00 & 0.67 & 3.33 \\
\hline US & $\mathrm{AL}$ & Nurse & Nurse & 0.00 & 0.92 & 0.00 & 0.92 & US & SD & Nurse & Nurse & 0.00 & 0.92 & 0.00 & 0.92 \\
\hline US & AR & Professional & Accountant & 0.00 & 0.00 & 0.00 & 0.00 & US & TN & Professional & Accountant & 0.00 & 0.00 & 0.00 & 0.00 \\
\hline US & AR & Professional & Architect & 0.00 & 1.50 & 0.00 & 1.50 & US & TN & Professional & Architect & 0.00 & 1.50 & 0.00 & 1.50 \\
\hline US & AR & Professional & Civil engineer & 0.00 & 1.67 & 0.00 & 1.67 & US & TN & Professional & Civil engineer & 0.00 & 1.50 & 0.00 & 1.50 \\
\hline US & AR & Professional & Lawyer & 0.00 & 1.25 & 0.00 & 1.25 & US & TN & Professional & Lawyer & 0.00 & 1.25 & 0.00 & 1.25 \\
\hline US & AR & Professional & Real-estate agent & 0.00 & 0.83 & 0.67 & 1.50 & US & TN & Professional & Real-estate agent & 0.00 & 0.83 & 0.67 & 1.50 \\
\hline US & AR & Personal & Aesthetician & 0.00 & 0.83 & 0.67 & 1.50 & US & TN & Personal & Aesthetician & 0.00 & 0.58 & 0.00 & 0.58 \\
\hline US & AR & Personal & Baker & 0.00 & 0.00 & 0.00 & 0.00 & US & TN & Personal & Baker & 0.00 & 0.00 & 0.00 & 0.00 \\
\hline US & AR & Personal & Butcher & 0.00 & 0.00 & 0.00 & 0.00 & US & TN & Personal & Butcher & 0.00 & 0.00 & 0.00 & 0.00 \\
\hline
\end{tabular}


ECO/WKP(2020)14 | 65

\begin{tabular}{|c|c|c|c|c|c|c|c|c|c|c|c|c|c|c|c|}
\hline US & AR & Personal & Driving instructor & 0.00 & 0.58 & 0.67 & 1.25 & US & TN & Personal & Driving instructor & 0.00 & 0.75 & 0.67 & 1.42 \\
\hline US & AR & Personal & Electrician & 0.00 & 1.25 & 0.00 & 1.25 & US & TN & Personal & Electrician & 0.67 & 1.00 & 0.00 & 1.67 \\
\hline US & AR & Personal & Hairdresser & 0.00 & 0.83 & 0.67 & 1.50 & US & TN & Personal & Hairdresser & 0.00 & 0.58 & 0.00 & 0.58 \\
\hline US & AR & Personal & Painter-decorator & 0.00 & 0.00 & 0.00 & 0.00 & US & $\mathrm{TN}$ & Personal & Painter-decorator & 0.00 & 0.00 & 0.00 & 0.00 \\
\hline US & AR & Personal & Plumber & 0.00 & 1.25 & 0.00 & 1.25 & US & TN & Personal & Plumber & 0.67 & 1.00 & 0.67 & 2.33 \\
\hline US & AR & Personal & Taxi driver & 0.67 & 2.00 & 0.67 & 3.33 & US & TN & Personal & Taxi driver & 0.67 & 1.33 & 0.67 & 2.67 \\
\hline US & $A R$ & Nurse & Nurse & 0.00 & 0.92 & 0.00 & 0.92 & US & $\mathrm{TN}$ & Nurse & Nurse & 0.00 & 0.92 & 0.00 & 0.92 \\
\hline US & $A Z$ & Professional & Accountant & 0.00 & 0.00 & 0.00 & 0.00 & US & TX & Professional & Accountant & 0.00 & 0.00 & 0.00 & 0.00 \\
\hline US & $A Z$ & Professional & Architect & 0.00 & 1.50 & 0.00 & 1.50 & US & $T X$ & Professional & Architect & 0.00 & 1.50 & 0.00 & 1.50 \\
\hline US & $A Z$ & Professional & Civil engineer & 0.00 & 0.92 & 0.00 & 0.92 & US & TX & Professional & Civil engineer & 0.00 & 1.42 & 0.00 & 1.42 \\
\hline US & $A Z$ & Professional & Lawyer & 1.33 & 1.50 & 0.00 & 2.83 & US & $\mathrm{TX}$ & Professional & Lawyer & 0.67 & 1.50 & 0.00 & 2.17 \\
\hline US & $A Z$ & Professional & Real-estate agent & 0.00 & 0.83 & 0.67 & 1.50 & US & $\mathrm{TX}$ & Professional & Real-estate agent & 0.00 & 0.83 & 0.67 & 1.50 \\
\hline US & $A Z$ & Personal & Aesthetician & 0.00 & 0.83 & 0.00 & 0.83 & US & $T X$ & Personal & Aesthetician & 0.00 & 0.58 & 0.00 & 0.58 \\
\hline US & $A Z$ & Personal & Baker & 0.00 & 0.00 & 0.00 & 0.00 & US & TX & Personal & Baker & 0.00 & 0.00 & 0.00 & 0.00 \\
\hline US & $A Z$ & Personal & Butcher & 0.00 & 0.00 & 0.00 & 0.00 & US & TX & Personal & Butcher & 0.00 & 0.00 & 0.00 & 0.00 \\
\hline US & $A Z$ & Personal & Driving instructor & 0.00 & 0.83 & 0.67 & 1.50 & US & $T X$ & Personal & Driving instructor & 0.00 & 0.33 & 0.67 & 1.00 \\
\hline US & $A Z$ & Personal & Electrician & 0.67 & 0.75 & 0.67 & 2.08 & US & TX & Personal & Electrician & 0.67 & 1.42 & 0.00 & 2.08 \\
\hline US & $A Z$ & Personal & Hairdresser & 0.00 & 0.83 & 0.00 & 0.83 & US & $T X$ & Personal & Hairdresser & 0.00 & 0.58 & 0.00 & 0.58 \\
\hline US & $A Z$ & Personal & Painter-decorator & 0.00 & 0.00 & 0.00 & 0.00 & US & $T X$ & Personal & Painter-decorator & 0.00 & 0.00 & 0.00 & 0.00 \\
\hline US & $A Z$ & Personal & Plumber & 0.67 & 1.25 & 0.67 & 2.58 & US & TX & Personal & Plumber & 0.00 & 1.00 & 0.00 & 1.00 \\
\hline US & $A Z$ & Personal & Taxi driver & 0.00 & 0.00 & 0.00 & 0.00 & US & $T X$ & Personal & Taxi driver & 0.00 & 0.00 & 0.00 & 0.00 \\
\hline US & $A Z$ & Nurse & Nurse & 0.00 & 0.92 & 0.67 & 1.58 & US & TX & Nurse & Nurse & 0.00 & 0.92 & 0.00 & 0.92 \\
\hline US & $C A$ & Professional & Accountant & 0.00 & 0.96 & 0.00 & 0.96 & US & UT & Professional & Accountant & 0.00 & 0.00 & 0.00 & 0.00 \\
\hline US & $\mathrm{CA}$ & Professional & Architect & 0.00 & 1.50 & 0.67 & 2.17 & US & UT & Professional & Architect & 0.00 & 1.50 & 0.00 & 1.50 \\
\hline US & CA & Professional & Civil engineer & 0.00 & 0.83 & 0.67 & 1.50 & US & UT & Professional & Civil engineer & 0.00 & 1.50 & 0.00 & 1.50 \\
\hline US & $\mathrm{CA}$ & Professional & Lawyer & 0.67 & 1.00 & 0.67 & 2.33 & US & UT & Professional & Lawyer & 0.67 & 1.50 & 0.00 & 2.17 \\
\hline US & $\mathrm{CA}$ & Professional & Real-estate agent & 0.00 & 0.83 & 0.67 & 1.50 & US & UT & Professional & Real-estate agent & 0.00 & 1.00 & 0.00 & 1.00 \\
\hline US & $\mathrm{CA}$ & Personal & Aesthetician & 0.00 & 1.00 & 0.00 & 1.00 & US & UT & Personal & Aesthetician & 0.00 & 1.00 & 0.00 & 1.00 \\
\hline US & $\mathrm{CA}$ & Personal & Baker & 0.00 & 0.00 & 0.00 & 0.00 & US & UT & Personal & Baker & 0.00 & 0.00 & 0.00 & 0.00 \\
\hline US & $\mathrm{CA}$ & Personal & Butcher & 0.00 & 0.00 & 0.00 & 0.00 & US & UT & Personal & Butcher & 0.00 & 0.00 & 0.00 & 0.00 \\
\hline US & $\mathrm{CA}$ & Personal & Driving instructor & 0.00 & 1.08 & 0.67 & 1.75 & US & UT & Personal & Driving instructor & 0.00 & 1.08 & 1.33 & 2.42 \\
\hline US & $\mathrm{CA}$ & Personal & Electrician & 0.00 & 1.42 & 0.00 & 1.42 & US & UT & Personal & Electrician & 0.00 & 1.42 & 0.00 & 1.42 \\
\hline US & $\mathrm{CA}$ & Personal & Hairdresser & 0.00 & 1.00 & 0.00 & 1.00 & US & UT & Personal & Hairdresser & 0.00 & 1.00 & 0.00 & 1.00 \\
\hline US & $\mathrm{CA}$ & Personal & Painter-decorator & 0.00 & 0.00 & 0.00 & 0.00 & US & UT & Personal & Painter-decorator & 0.00 & 0.00 & 0.00 & 0.00 \\
\hline US & $\mathrm{CA}$ & Personal & Plumber & 0.00 & 1.50 & 0.00 & 1.50 & US & UT & Personal & Plumber & 0.00 & 1.00 & 0.00 & 1.00 \\
\hline
\end{tabular}


66 | ECO/WKP(2020)14

\begin{tabular}{|c|c|c|c|c|c|c|c|c|c|c|c|c|c|c|c|}
\hline US & $\mathrm{CA}$ & Personal & Taxi driver & 0.67 & 1.00 & 0.67 & 2.33 & US & UT & Personal & Taxi driver & 0.00 & 0.00 & 0.00 & 0.00 \\
\hline US & $\mathrm{CA}$ & Nurse & Nurse & 0.00 & 0.92 & 0.00 & 0.92 & US & UT & Nurse & Nurse & 0.00 & 0.92 & 0.00 & 0.92 \\
\hline US & $\mathrm{CO}$ & Professional & Accountant & 0.00 & 0.00 & 0.00 & 0.00 & US & VA & Professional & Accountant & 0.00 & 0.00 & 0.00 & 0.00 \\
\hline US & $\mathrm{CO}$ & Professional & Architect & 0.00 & 1.42 & 0.00 & 1.42 & US & VA & Professional & Architect & 0.00 & 1.50 & 0.00 & 1.50 \\
\hline US & $\mathrm{CO}$ & Professional & Civil engineer & 0.00 & 1.42 & 0.00 & 1.42 & US & VA & Professional & Civil engineer & 0.00 & 1.42 & 0.00 & 1.42 \\
\hline US & $\mathrm{CO}$ & Professional & Lawyer & 0.00 & 1.25 & 0.00 & 1.25 & US & VA & Professional & Lawyer & 0.67 & 1.50 & 0.00 & 2.17 \\
\hline US & $\mathrm{CO}$ & Professional & Real-estate agent & 0.00 & 1.42 & 0.67 & 2.08 & US & VA & Professional & Real-estate agent & 0.00 & 0.83 & 0.67 & 1.50 \\
\hline US & $\mathrm{CO}$ & Personal & Aesthetician & 0.00 & 0.58 & 0.00 & 0.58 & US & VA & Personal & Aesthetician & 0.00 & 1.00 & 0.00 & 1.00 \\
\hline US & $\mathrm{CO}$ & Personal & Baker & 0.00 & 0.00 & 0.00 & 0.00 & US & VA & Personal & Baker & 0.00 & 0.00 & 0.00 & 0.00 \\
\hline US & $\mathrm{CO}$ & Personal & Butcher & 0.00 & 0.00 & 0.00 & 0.00 & US & VA & Personal & Butcher & 0.00 & 0.00 & 0.00 & 0.00 \\
\hline US & $\mathrm{CO}$ & Personal & Driving instructor & 0.00 & 0.00 & 0.00 & 0.00 & US & VA & Personal & Driving instructor & 0.00 & 0.33 & 0.67 & 1.00 \\
\hline US & $\mathrm{CO}$ & Personal & Electrician & 0.00 & 1.33 & 0.00 & 1.33 & US & VA & Personal & Electrician & 0.00 & 1.00 & 0.00 & 1.00 \\
\hline US & $\mathrm{CO}$ & Personal & Hairdresser & 0.00 & 0.58 & 0.00 & 0.58 & US & VA & Personal & Hairdresser & 0.00 & 1.00 & 0.00 & 1.00 \\
\hline US & $\mathrm{CO}$ & Personal & Painter-decorator & 0.00 & 0.00 & 0.00 & 0.00 & US & VA & Personal & Painter-decorator & 0.00 & 0.00 & 0.00 & 0.00 \\
\hline US & $\mathrm{CO}$ & Personal & Plumber & 0.00 & 0.75 & 0.00 & 0.75 & US & VA & Personal & Plumber & 0.00 & 1.00 & 0.00 & 1.00 \\
\hline US & $\mathrm{CO}$ & Personal & Taxi driver & 0.00 & 0.00 & 0.00 & 0.00 & US & VA & Personal & Taxi driver & 1.33 & 0.50 & 0.67 & 2.50 \\
\hline US & $\mathrm{CO}$ & Nurse & Nurse & 0.00 & 1.33 & 0.00 & 1.33 & US & VA & Nurse & Nurse & 0.00 & 0.92 & 0.00 & 0.92 \\
\hline US & $\mathrm{CT}$ & Professional & Accountant & 0.00 & 0.00 & 0.00 & 0.00 & US & VT & Professional & Accountant & 0.00 & 0.00 & 0.00 & 0.00 \\
\hline US & СT & Professional & Architect & 0.00 & 1.50 & 0.00 & 1.50 & US & VT & Professional & Architect & 0.00 & 1.50 & 0.00 & 1.50 \\
\hline US & $\mathrm{CT}$ & Professional & Civil engineer & 0.00 & 1.67 & 0.00 & 1.67 & US & VT & Professional & Civil engineer & 0.00 & 1.00 & 0.00 & 1.00 \\
\hline US & CT & Professional & Lawyer & 0.00 & 1.50 & 0.00 & 1.50 & US & VT & Professional & Lawyer & 0.00 & 1.67 & 0.00 & 1.67 \\
\hline US & CT & Professional & Real-estate agent & 0.00 & 0.58 & 0.00 & 0.58 & US & VT & Professional & Real-estate agent & 0.00 & 0.83 & 0.67 & 1.50 \\
\hline US & CT & Personal & Aesthetician & 0.00 & 0.00 & 0.00 & 0.00 & US & VT & Personal & Aesthetician & 0.00 & 1.00 & 0.67 & 1.67 \\
\hline US & СТ & Personal & Baker & 0.00 & 0.00 & 0.00 & 0.00 & US & VT & Personal & Baker & 0.00 & 0.00 & 0.00 & 0.00 \\
\hline US & CT & Personal & Butcher & 0.00 & 0.00 & 0.00 & 0.00 & US & VT & Personal & Butcher & 0.00 & 0.00 & 0.00 & 0.00 \\
\hline US & CT & Personal & Driving instructor & 0.00 & 0.83 & 0.67 & 1.50 & US & VT & Personal & Driving instructor & 0.00 & 0.50 & 0.67 & 1.17 \\
\hline US & CT & Personal & Electrician & 0.00 & 1.67 & 0.00 & 1.67 & US & VT & Personal & Electrician & 0.00 & 1.67 & 0.00 & 1.67 \\
\hline US & $\mathrm{CT}$ & Personal & Hairdresser & 0.00 & 0.58 & 0.00 & 0.58 & US & VT & Personal & Hairdresser & 0.67 & 1.00 & 0.67 & 2.33 \\
\hline US & $\mathrm{CT}$ & Personal & Painter-decorator & 0.00 & 0.00 & 0.00 & 0.00 & US & VT & Personal & Painter-decorator & 0.00 & 0.00 & 0.00 & 0.00 \\
\hline US & СT & Personal & Plumber & 0.00 & 1.17 & 0.00 & 1.17 & US & VT & Personal & Plumber & 0.00 & 1.25 & 0.00 & 1.25 \\
\hline US & CT & Personal & Taxi driver & 0.00 & 0.50 & 0.67 & 1.17 & US & VT & Personal & Taxi driver & 0.00 & 0.00 & 0.00 & 0.00 \\
\hline US & CT & Nurse & Nurse & 0.00 & 0.92 & 0.00 & 0.92 & US & VT & Nurse & Nurse & 0.00 & 0.92 & 0.00 & 0.92 \\
\hline US & $\mathrm{DC}$ & Professional & Accountant & 0.00 & 0.00 & 0.00 & 0.00 & US & WA & Professional & Accountant & 0.00 & 0.00 & 0.00 & 0.00 \\
\hline US & $\mathrm{DC}$ & Professional & Architect & 0.00 & 1.50 & 0.00 & 1.50 & US & WA & Professional & Architect & 0.00 & 1.50 & 0.67 & 2.17 \\
\hline US & $\mathrm{DC}$ & Professional & Civil engineer & 0.00 & 1.42 & 0.00 & 1.42 & US & WA & Professional & Civil engineer & 0.00 & 1.25 & 0.00 & 1.25 \\
\hline
\end{tabular}


ECO/WKP(2020)14 | 67

\begin{tabular}{|c|c|c|c|c|c|c|c|c|c|c|c|c|c|c|c|}
\hline US & $\mathrm{DC}$ & Professional & Lawyer & 0.67 & 1.00 & 0.00 & 1.67 & US & WA & Professional & Lawyer & 0.67 & 1.25 & 0.00 & 1.92 \\
\hline US & $\mathrm{DC}$ & Professional & Real-estate agent & 0.00 & 1.08 & 0.67 & 1.75 & US & WA & Professional & Real-estate agent & 0.00 & 0.83 & 0.67 & 1.50 \\
\hline US & $\mathrm{DC}$ & Personal & Aesthetician & 0.00 & 1.08 & 0.00 & 1.08 & US & WA & Personal & Aesthetician & 0.00 & 1.00 & 0.00 & 1.00 \\
\hline US & $\mathrm{DC}$ & Personal & Baker & 0.00 & 0.00 & 0.00 & 0.00 & US & WA & Personal & Baker & 0.00 & 0.00 & 0.00 & 0.00 \\
\hline US & $\mathrm{DC}$ & Personal & Butcher & 0.00 & 0.00 & 0.00 & 0.00 & US & WA & Personal & Butcher & 0.00 & 0.00 & 0.00 & 0.00 \\
\hline US & $\mathrm{DC}$ & Personal & Driving instructor & 0.00 & 1.00 & 1.33 & 2.33 & US & WA & Personal & Driving instructor & 0.00 & 0.83 & 1.33 & 2.17 \\
\hline US & $\mathrm{DC}$ & Personal & Electrician & 0.00 & 1.42 & 0.00 & 1.42 & US & WA & Personal & Electrician & 0.00 & 1.08 & 0.00 & 1.08 \\
\hline US & $\mathrm{DC}$ & Personal & Hairdresser & 0.00 & 1.00 & 0.67 & 1.67 & US & WA & Personal & Hairdresser & 0.00 & 1.00 & 0.00 & 1.00 \\
\hline US & $\mathrm{DC}$ & Personal & Painter-decorator & 0.00 & 0.00 & 0.00 & 0.00 & US & WA & Personal & Painter-decorator & 0.00 & 0.00 & 0.00 & 0.00 \\
\hline US & $\mathrm{DC}$ & Personal & Plumber & 0.00 & 1.42 & 0.00 & 1.42 & US & WA & Personal & Plumber & 0.00 & 1.50 & 0.00 & 1.50 \\
\hline US & $\mathrm{DC}$ & Personal & Taxi driver & 0.00 & 1.00 & 0.67 & 1.67 & US & WA & Personal & Taxi driver & 0.67 & 0.50 & 0.67 & 1.83 \\
\hline US & $\mathrm{DC}$ & Nurse & Nurse & 0.00 & 0.92 & 0.00 & 0.92 & US & WA & Nurse & Nurse & 0.00 & 1.17 & 0.00 & 1.17 \\
\hline US & $\mathrm{DE}$ & Professional & Accountant & 0.00 & 0.00 & 0.00 & 0.00 & US & WI & Professional & Accountant & 0.00 & 0.00 & 0.00 & 0.00 \\
\hline US & $\mathrm{DE}$ & Professional & Architect & 0.00 & 1.50 & 0.00 & 1.50 & US & WI & Professional & Architect & 0.00 & 1.50 & 0.00 & 1.50 \\
\hline US & $\mathrm{DE}$ & Professional & Civil engineer & 0.67 & 1.00 & 0.00 & 1.67 & US & WI & Professional & Civil engineer & 0.00 & 1.42 & 0.00 & 1.42 \\
\hline US & $\mathrm{DE}$ & Professional & Lawyer & 0.00 & 1.75 & 0.00 & 1.75 & US & WI & Professional & Lawyer & 0.67 & 1.50 & 0.00 & 2.17 \\
\hline US & $\mathrm{DE}$ & Professional & Real-estate agent & 0.00 & 0.83 & 0.67 & 1.50 & US & WI & Professional & Real-estate agent & 0.00 & 0.58 & 0.67 & 1.25 \\
\hline US & $\mathrm{DE}$ & Personal & Aesthetician & 0.00 & 1.00 & 0.00 & 1.00 & US & WI & Personal & Aesthetician & 0.00 & 0.58 & 0.00 & 0.58 \\
\hline US & $\mathrm{DE}$ & Personal & Baker & 0.00 & 0.00 & 0.00 & 0.00 & US & WI & Personal & Baker & 0.00 & 0.00 & 0.00 & 0.00 \\
\hline US & $\mathrm{DE}$ & Personal & Butcher & 0.00 & 0.00 & 0.00 & 0.00 & US & WI & Personal & Butcher & 0.00 & 0.00 & 0.00 & 0.00 \\
\hline US & $\mathrm{DE}$ & Personal & Driving instructor & 0.00 & 0.83 & 0.67 & 1.50 & US & WI & Personal & Driving instructor & 0.00 & 0.33 & 0.67 & 1.00 \\
\hline US & $\mathrm{DE}$ & Personal & Electrician & 0.00 & 1.67 & 0.00 & 1.67 & US & WI & Personal & Electrician & 0.00 & 1.42 & 0.00 & 1.42 \\
\hline US & $\mathrm{DE}$ & Personal & Hairdresser & 0.00 & 1.00 & 0.00 & 1.00 & US & WI & Personal & Hairdresser & 0.00 & 1.00 & 0.00 & 1.00 \\
\hline US & $\mathrm{DE}$ & Personal & Painter-decorator & 0.00 & 0.00 & 0.00 & 0.00 & US & WI & Personal & Painter-decorator & 0.00 & 0.00 & 0.00 & 0.00 \\
\hline US & $\mathrm{DE}$ & Personal & Plumber & 0.00 & 0.99 & 0.00 & 0.99 & US & WI & Personal & Plumber & 0.00 & 1.17 & 0.00 & 1.17 \\
\hline US & $\mathrm{DE}$ & Personal & Taxi driver & 0.00 & 1.08 & 0.67 & 1.75 & US & WI & Personal & Taxi driver & 0.67 & 0.33 & 0.67 & 1.67 \\
\hline US & $\mathrm{DE}$ & Nurse & Nurse & 0.00 & 0.92 & 0.00 & 0.92 & US & WI & Nurse & Nurse & 0.00 & 0.92 & 0.00 & 0.92 \\
\hline US & $\mathrm{FL}$ & Professional & Accountant & 0.00 & 0.00 & 0.00 & 0.00 & US & WV & Professional & Accountant & 0.00 & 0.00 & 0.00 & 0.00 \\
\hline US & $\mathrm{FL}$ & Professional & Architect & 0.00 & 1.50 & 0.00 & 1.50 & US & WV & Professional & Architect & 0.00 & 1.50 & 0.00 & 1.50 \\
\hline US & $\mathrm{FL}$ & Professional & Civil engineer & 0.00 & 1.42 & 0.00 & 1.42 & US & WV & Professional & Civil engineer & 0.00 & 1.42 & 0.00 & 1.42 \\
\hline US & $\mathrm{FL}$ & Professional & Lawyer & 0.67 & 1.00 & 0.67 & 2.33 & US & WV & Professional & Lawyer & 0.67 & 1.00 & 0.00 & 1.67 \\
\hline US & $\mathrm{FL}$ & Professional & Real-estate agent & 0.00 & 0.58 & 0.67 & 1.25 & US & WV & Professional & Real-estate agent & 0.00 & 0.83 & 0.00 & 0.83 \\
\hline US & $\mathrm{FL}$ & Personal & Aesthetician & 0.00 & 0.58 & 0.00 & 0.58 & US & WV & Personal & Aesthetician & 0.00 & 0.83 & 0.67 & 1.50 \\
\hline US & $\mathrm{FL}$ & Personal & Baker & 0.00 & 0.00 & 0.00 & 0.00 & US & WV & Personal & Baker & 0.00 & 0.00 & 0.00 & 0.00 \\
\hline US & $\mathrm{FL}$ & Personal & Butcher & 0.00 & 0.00 & 0.00 & 0.00 & US & WV & Personal & Butcher & 0.00 & 0.00 & 0.00 & 0.00 \\
\hline
\end{tabular}


68 | ECO/WKP(2020)14

\begin{tabular}{|c|c|c|c|c|c|c|c|c|c|c|c|c|c|c|c|}
\hline US & $\mathrm{FL}$ & Personal & Driving instructor & 0.00 & 0.33 & 0.67 & 1.00 & US & WV & Personal & Driving instructor & 0.00 & 0.58 & 0.00 & 0.58 \\
\hline US & $\mathrm{FL}$ & Personal & Electrician & 0.67 & 2.00 & 0.00 & 2.67 & US & WV & Personal & Electrician & 0.00 & 1.25 & 0.00 & 1.25 \\
\hline US & $\mathrm{FL}$ & Personal & Hairdresser & 0.00 & 0.83 & 0.00 & 0.83 & US & WV & Personal & Hairdresser & 0.00 & 0.67 & 1.33 & 2.00 \\
\hline US & $\mathrm{FL}$ & Personal & Painter-decorator & 0.00 & 0.00 & 0.00 & 0.00 & US & WV & Personal & Painter-decorator & 0.00 & 0.00 & 0.00 & 0.00 \\
\hline US & $\mathrm{FL}$ & Personal & Plumber & 0.67 & 1.42 & 0.00 & 2.08 & US & WV & Personal & Plumber & 0.67 & 1.25 & 0.00 & 1.92 \\
\hline US & $\mathrm{FL}$ & Personal & Taxi driver & 0.00 & 0.00 & 0.00 & 0.00 & US & WV & Personal & Taxi driver & 0.00 & 0.50 & 0.67 & 1.17 \\
\hline US & $\mathrm{FL}$ & Nurse & Nurse & 0.00 & 0.92 & 0.00 & 0.92 & US & WV & Nurse & Nurse & 0.00 & 0.92 & 0.00 & 0.92 \\
\hline US & GA & Professional & Accountant & 0.00 & 0.00 & 0.00 & 0.00 & US & WY & Professional & Accountant & 0.00 & 0.00 & 0.00 & 0.00 \\
\hline US & GA & Professional & Architect & 0.00 & 1.42 & 0.00 & 1.42 & US & WY & Professional & Architect & 0.00 & 1.50 & 0.00 & 1.50 \\
\hline US & GA & Professional & Civil engineer & 0.00 & 1.42 & 0.00 & 1.42 & US & WY & Professional & Civil engineer & 0.00 & 1.00 & 0.00 & 1.00 \\
\hline US & GA & Professional & Lawyer & 0.67 & 1.00 & 0.00 & 1.67 & US & WY & Professional & Lawyer & 0.67 & 1.00 & 0.00 & 1.67 \\
\hline US & GA & Professional & Real-estate agent & 0.00 & 0.83 & 0.00 & 0.83 & US & WY & Professional & Real-estate agent & 0.00 & 0.83 & 0.67 & 1.50 \\
\hline US & GA & Personal & Aesthetician & 0.00 & 1.00 & 0.00 & 1.00 & US & WY & Personal & Aesthetician & 0.00 & 0.58 & 0.00 & 0.58 \\
\hline US & GA & Personal & Baker & 0.00 & 0.00 & 0.00 & 0.00 & US & WY & Personal & Baker & 0.00 & 0.00 & 0.00 & 0.00 \\
\hline US & GA & Personal & Butcher & 0.00 & 0.00 & 0.00 & 0.00 & US & WY & Personal & Butcher & 0.00 & 0.00 & 0.00 & 0.00 \\
\hline US & GA & Personal & Driving instructor & 0.00 & 0.33 & 0.67 & 1.00 & US & WY & Personal & Driving instructor & 0.00 & 0.92 & 0.67 & 1.58 \\
\hline US & GA & Personal & Electrician & 0.67 & 1.00 & 0.00 & 1.67 & US & WY & Personal & Electrician & 0.00 & 1.08 & 0.00 & 1.08 \\
\hline US & GA & Personal & Hairdresser & 0.00 & 1.00 & 0.00 & 1.00 & US & WY & Personal & Hairdresser & 0.00 & 0.58 & 0.00 & 0.58 \\
\hline US & GA & Personal & Painter-decorator & 0.00 & 0.00 & 0.00 & 0.00 & US & WY & Personal & Painter-decorator & 0.00 & 0.00 & 0.00 & 0.00 \\
\hline US & GA & Personal & Plumber & 0.00 & 1.00 & 0.00 & 1.00 & US & WY & Personal & Plumber & 0.00 & 1.00 & 0.00 & 1.00 \\
\hline US & GA & Personal & Taxi driver & 0.00 & 0.25 & 0.67 & 0.92 & US & WY & Personal & Taxi driver & 0.67 & 0.50 & 0.67 & 1.83 \\
\hline US & GA & Nurse & Nurse & 0.00 & 1.42 & 0.00 & 1.42 & US & WY & Nurse & Nurse & 0.00 & 0.92 & 0.00 & 0.92 \\
\hline US & $\mathrm{HI}$ & Professional & Accountant & 0.00 & 0.00 & 0.00 & 0.00 & ZAF & ZAF & Professional & Accountant & 0.67 & 1.67 & 0.00 & 2.33 \\
\hline US & $\mathrm{HI}$ & Professional & Architect & 0.00 & 1.00 & 0.00 & 1.00 & ZAF & ZAF & Professional & Architect & 0.67 & 1.83 & 0.67 & 3.17 \\
\hline US & $\mathrm{HI}$ & Professional & Civil engineer & 0.00 & 1.42 & 0.00 & 1.42 & ZAF & ZAF & Professional & Civil engineer & 0.67 & 1.58 & 0.67 & 2.92 \\
\hline US & $\mathrm{HI}$ & Professional & Lawyer & 0.67 & 1.25 & 0.67 & 2.58 & ZAF & ZAF & Professional & Lawyer & 0.67 & 1.92 & 0.67 & 3.25 \\
\hline US & $\mathrm{HI}$ & Professional & Real-estate agent & 0.00 & 1.00 & 0.67 & 1.67 & $\mathrm{ZAF}$ & ZAF & Professional & Real-estate agent & 0.67 & 1.67 & 1.33 & 3.67 \\
\hline US & $\mathrm{HI}$ & Personal & Aesthetician & 0.00 & 1.00 & 0.67 & 1.67 & ZAF & ZAF & Personal & Aesthetician & 0.00 & 0.00 & 0.00 & 0.00 \\
\hline US & $\mathrm{HI}$ & Personal & Baker & 0.00 & 0.00 & 0.00 & 0.00 & ZAF & ZAF & Personal & Baker & 0.00 & 0.00 & 0.00 & 0.00 \\
\hline US & $\mathrm{HI}$ & Personal & Butcher & 0.00 & 0.00 & 0.00 & 0.00 & ZAF & ZAF & Personal & Butcher & 0.00 & 0.00 & 0.00 & 0.00 \\
\hline US & $\mathrm{HI}$ & Personal & Driving instructor & 0.00 & 0.33 & 0.67 & 1.00 & $\mathrm{ZAF}$ & ZAF & Personal & Driving instructor & 0.00 & 1.00 & 0.00 & 1.00 \\
\hline US & $\mathrm{HI}$ & Personal & Electrician & 0.00 & 1.33 & 0.67 & 2.00 & $\mathrm{ZAF}$ & ZAF & Personal & Electrician & 0.47 & 0.76 & 0.00 & 1.23 \\
\hline US & $\mathrm{HI}$ & Personal & Hairdresser & 0.00 & 1.00 & 0.67 & 1.67 & $\mathrm{ZAF}$ & ZAF & Personal & Hairdresser & 0.00 & 0.00 & 0.00 & 0.00 \\
\hline US & $\mathrm{HI}$ & Personal & Painter-decorator & 0.00 & 0.00 & 0.00 & 0.00 & ZAF & ZAF & Personal & Painter-decorator & 0.00 & 0.00 & 0.00 & 0.00 \\
\hline US & $\mathrm{HI}$ & Personal & Plumber & 0.00 & 1.25 & 0.67 & 1.92 & ZAF & ZAF & Personal & Plumber & 0.93 & 0.70 & 0.00 & 1.63 \\
\hline
\end{tabular}


ECO/WKP(2020)14 | 69

\begin{tabular}{|c|c|c|c|c|c|c|c|c|c|c|c|c|c|c|c|}
\hline US & $\mathrm{HI}$ & Personal & Taxi driver & 0.67 & 0.75 & 0.67 & 2.08 & ZAF & ZAF & Personal & Taxi driver & 0.00 & 1.00 & 0.67 & 1.67 \\
\hline US & $\mathrm{HI}$ & Nurse & Nurse & 0.00 & 0.92 & 0.00 & 0.92 & ZAF & ZAF & Nurse & Nurse & 0.67 & 1.50 & 0.67 & 2.83 \\
\hline US & IA & Professional & Accountant & 0.00 & 0.00 & 0.00 & 0.00 & & & & & & & & \\
\hline US & IA & Professional & Architect & 0.00 & 1.50 & 0.00 & 1.50 & & & & & & & & \\
\hline US & IA & Professional & Civil engineer & 0.00 & 1.42 & 0.00 & 1.42 & & & & & & & & \\
\hline US & $\mathrm{IA}$ & Professional & Lawyer & 0.00 & 1.25 & 0.00 & 1.25 & & & & & & & & \\
\hline US & $\mathrm{IA}$ & Professional & Real-estate agent & 0.00 & 0.83 & 0.00 & 0.83 & & & & & & & & \\
\hline US & IA & Personal & Aesthetician & 0.00 & 0.83 & 0.00 & 0.83 & & & & & & & & \\
\hline US & $\mathrm{IA}$ & Personal & Baker & 0.00 & 0.00 & 0.00 & 0.00 & & & & & & & & \\
\hline US & IA & Personal & Butcher & 0.00 & 0.00 & 0.00 & 0.00 & & & & & & & & \\
\hline US & IA & Personal & Driving instructor & 0.00 & 0.33 & 0.67 & 1.00 & & & & & & & & \\
\hline US & IA & Personal & Electrician & 0.00 & 1.00 & 0.00 & 1.00 & & & & & & & & \\
\hline US & IA & Personal & Hairdresser & 0.00 & 0.67 & 0.00 & 0.67 & & & & & & & & \\
\hline US & $\mathrm{IA}$ & Personal & Painter-decorator & 0.00 & 0.00 & 0.00 & 0.00 & & & & & & & & \\
\hline US & IA & Personal & Plumber & 0.00 & 1.17 & 0.00 & 1.17 & & & & & & & & \\
\hline US & $\mathrm{IA}$ & Personal & Taxi driver & 0.00 & 0.58 & 0.67 & 1.25 & & & & & & & & \\
\hline US & $\mathrm{IA}$ & Nurse & Nurse & 0.00 & 1.42 & 0.00 & 1.42 & & & & & & & & \\
\hline
\end{tabular}

